
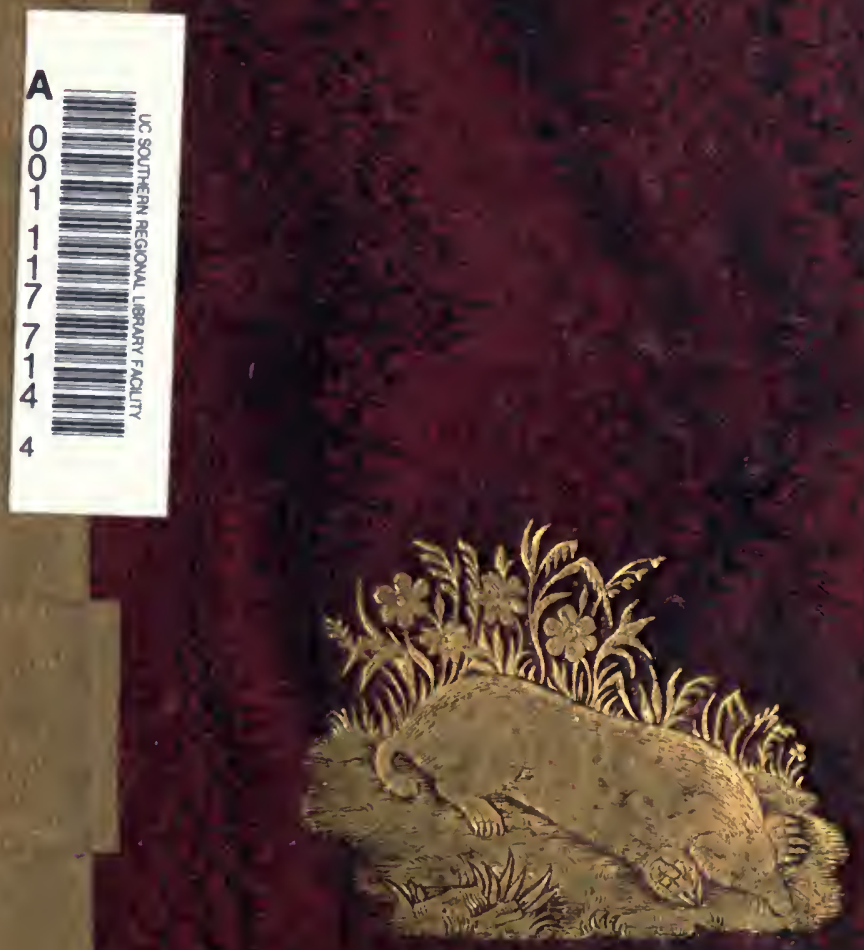

4 


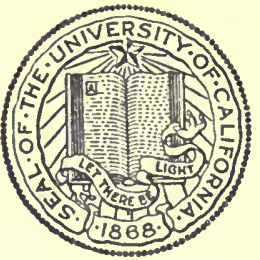

THE LIBRARY OF

\section{THE UNIVERSITY OF CALIFORNIA LOS ANGELES}

Ex Libris

SIR MICHAEL SADLER

ACQUIRED $194^{8}$

WITH THE HELP OF ALUMNI OF THE SCHOOL OF EDUCATION 
Digitized by the Internet Archive in 2007 with funding from Microsoft Corporation 



\section{T' A L P A ;}

OR THY

CHRONICLES OF A CLAY FARM. 



\section{T A L P A :}

ox rum

\section{Chronicles of a Clay Farm.}

An Agricultural Fragment.

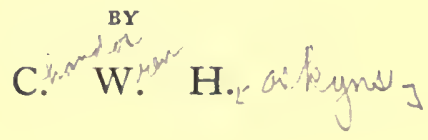

" __ RIDENTEM DICERE VERUM."

Stcond EDition.

LONDON :

REEVE \& CO., HENRIETTA ST., COVENT GARDEN. 


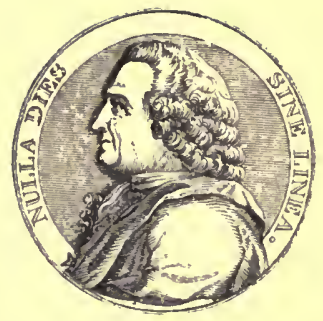

JOHN EDWABD TATLOR, PBINTER,

LITTLE QTEEN STREET, LINCOLN'S INN FIBLDS, 


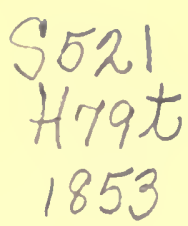

TO THE

READERS AND CONTRIBUTORS

OP THE

'Gardeners' Cyranicle and Agricultural Gaz̨ette' THIS RE-COLLECTION

OF SOME SCATTERED ESSAYS OF PAST YEARS

BASED ON TIIE HOPE AND BELIEF

NOT UNCONFIRMED AT TIEIR IUANDS

THAT AGRICCLTURAL THOUGHT MAY BE CANDID

$\triangle N D$ EVEN 'SPECLLATIVE'

IET ICSBANDRY NOT THE LESS PRACTICAL

IS FINALLY INSCRIBED BY

THE AUTHOR.

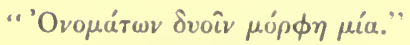





\section{ON T E N T S.}

[first sirrirs.]

I.

PAGE

THE WASTE

II.

TIIE DEVIL-ON-THREE-STICKS

III.

A PBACTICAL BEGINNING

IV.

A CONVERT, - AND A HBRETIC

$\Gamma$

COMBINATION AND COMMINCTION.

VI.

CALX - AND BRCALCITBATION

VII.

EARTH-STOPPING

VIII.

'TRUTH AT THE BOTTOM OF A'-MARL-PIT . . . 49

IX.

PALLOWS-AND WIAT FOLLOWS

$\mathbf{X}$.

TIEORY AND PRACTICE .

II.

DISSOLFIXG TIEKS 
A WORD AT PARTING

\section{[S̈rcond Šcriss.]}

XIII.

'FARM TO LET'

XIV.

AN APPLICATION

XV.

'LANDLOBD AND TENANT'

XVI.

LOW PRICES AND LONG FACES

XVII.

A MATUTINAL HOUR

XVIII.

TALPA LOQUITUR

\section{XIX.}

THE 'POWERS' THAT BE

XX.

THE PLAIN EXGLISH OF IT

XXI.

THE STEAM-CULTIVATOR

XXII.

THE SUBJECT CONTINTED

XXIII.

XXIV. 


\title{
LIST OF VIGNETTES.
}

\author{
BY GEORGE CRUIKSIIANK.
}

PAGR

A. Sketch-introductory $\quad . \quad+\quad . \quad . \quad 7$

'Has it erer been tried with a Spirit-lerel?' - . . . 12

- As the weakest link of a chain is the measure of its strength' . . . . . . . . . . . 19

'In spite of forty years' experience to the contrary' . $\quad 26$

"Mingle, mingle, mingle,

Ye that mingle may" . . . . . 35

' $\mathbf{\text { sort }}$ of jorial rebellion against the long despotism of Jack Frost'

'Down went the Fences, notwithstanding' . . . . . . 18

'The bright little sentinels of IIearen were taking one by one their watch-posts' . . . . . . . . 57

'The Wisard of the Pacific' . . . . . . . 66;

"I had the same profound respect for each and both" . $\$ 1$

"Fheu! quantus equis, quantus erat sudor Viris!" . . . . . . . . . 86

'On through the silent night,-

While wenry labourers aleep,-still worke, alone" . . 9.1. 
'I say, Mr. Bowles, have you seen this Farm that's adrertised here?' . . . . . . . 104

- 'but the mischief lies in the corollary - 'so muel for your Science!'

-'In whielı there is at once Antagonisn of interest yet Mutu. ality of objeet'

'All up with Farming I doubt!' . . . . . . 136

'Indicating tliat whieh was, and is no longer' . . $\quad 146$

'We shall learn of him another and a greater lesson, some day'

'It's his first year at plough: he was 'bipping eraows' for the last two or three'

'Steam-power, - no more to do with the Plough than a horse has to do with a Spade' . . . . . . . 187

'The willing giant stands idly panting and smoking' . . 198

'Vestigia nulla retrorsum' . . . . . . . 214

'Incontinently bent on their baptism of natire mud' . $\quad 224$ The End' . . . . . . . . . 237 


\section{CHRONICLES OF A CLAY FARM.}

[FIRST SERIES.]

I.

THE WASTE.

Мuch as may be learnt, by a willing mind, from the wisdom of others, the most practical, and (shame upon us!) the most attractive lessons secm always to be derived from their failures. It is too late, in the natural history of the "biped without featlecrs that laughs," to stop and inquire into this little item from the list of his peculiarities; so I shall take it for granted in the most practical and amiable way in which it can be at once assumed and applied; and like the self-devoted bird, that plueks its own breast to feed the young brood, open up my early farming blunders to the instruetive gaze of those young and 
ardent agrieulturists who are just begimning to recognize the last of human Scienees in the first of human Arts, and to "only wish, like dutcous sons, their parents were more wisc."

I shall not tell when it was, nor where it was, nol' why it was, that I first 'broke ground:' the first would be too eruel, the second too particular, and the third too personal. But I shall deseribe my Farm geologically, and myself eategorically, which must answer every proper inquiry of the eurious, and will leave a little untold besides, the better to keep alive the interest of the narrative.

Somewhere or other in England there is a flat, bleak, high-lying distriet, which a shallow or very terse geologist might haply describe as part of the New red-sandstone formation; but where, if he would take the trouble to plough an acre, he would hear now and then a suspicious kind of sound from the share and eoulter, which I may describe by. the word 'soapy;' and where, whenerer the nose of the plough ehaneed to dive an ineh deeper than usual, he would see certain blue-looking indieations turned up, that would rather startle his complaecney, if a lorer of light soils, by a suggestion of the proximity of that terrible antagonist-the bhe Lias. Should this dis- 
corery stimulate further exploration, and his plough be set a couple of inches decper, his ears might presently be regaled with a sound as of a heary-laden eart dragging orer a newly-gravelled road; and after turning up a variety of conglomerates, as compacted as the bed of an old Roman causeway, and as manycoloured as Harlequin's eoat, the stress of the pull would suddenly be cased, and the plough be lieard swimming whisperingly through a bed of wet sand; and just as the filler-horse was congratulating himself that it was all plain sailing now, bang gocs a trace or a spreader, and the plough eomes to a standstill, just recealing, at the share-point, the bruised side of a quartz pebble, as big as a foot-ball, grimning at you from its tight nook in the bed of the furrow.

Have I described cnough? or shall I add, to this subsoil sketel, a faint and fecble idea of the surface, some time about the month of Febrnary (surnamed 'fill-dyke' not without reason); and endearonr to paint the hopeless, currentless, resonrecless, and pitiable condition of water, whose unhapyy fate has fallon, or melted, upon fields as flat as a billiard-table, and withont eren a 'pocket' to rum into for cseape or concealment? 'There it would stand, day after day, and weck after rreck, and month after montl, shining 
along the serpentine furrows, as if it never, never, never would go again! And the only wonder was when or how, or by what bold amphibious being the ridges liad ever been raised, which it interseeted, like a sample series of Dutch eanals and embankments.

This was my Farm : 250 statute acres !

"Why did you take it?"

I didn't. It took me. That 'mysterious lady' who is painted with a bandage on her eyes, (she ean see as well as you or I,) made it, with a pat on the back, my property, and shortly afterwards, with a slap in the face, my 'occupation.' It had been performing for a series of years a sort of ' geometrical progression' -downwards. Each ineoming tenant took it at about half the previous rent; dabbled about for a year or two like a duck, and retired-'lame.' It was but a simple equation-a very simple one-to say when the rent would eome to zero. It looked on the Rentalbook like an annual sum in Reduetion; facilis.deseensus Averni, literally translated into plain English. What was to be done with it? This brings me to my proposition No. 2: which is in fact what is eommonly called 'No. 1'-myself. If there was in the eatalogue of human pursuits, one which I hated and feared, dreaded and despised, didn't know, and didn't 
wish to know-it was that strange incomprchensible infatuated damaging thing which from my cradle upwards I had heard described and deprecated under the almost forbidden name of-Farming. Dr. Johnson calls it the delight of destiny to counterchange the plans and purposes of man; but some other wise man, I think it is Lord Bacon, tells us to ' choosc the life that is most uscful, and habit will make it the most agrecable.' But accident seems more potent than destiny, plan, purpose, choicc, or habit. On a long sca-voyage, and in a rather dull and resourceless forcign land, a couple of unbidden companions had stuck by me with persecuting tenacity, and attracted first my acquaintanee then my intimacy, for sheer want of anything else: they were two books: to wit, Cobbett's edition of Tull's Works, and the UsefulKnowledge Society's volumes on British Husbandry. I read them, and re-read them; and then began again: for nine mortal months $I$ was reduecd to gorge my litcrary appetite upon these husks, as 1 at first regarded them. The Georgies of Virgil had begun and ended all my previons aequaintanee with farming; they were the sole associating tie that conneeted me with this sudden and enforeed onslanght upon the 'theory and practice of Agriculture,' and I 
returned to England--poor wreteh,-in worse eondition than I went-in faet given up by the 'Faeulty' as a eonfirmed-Book-farmer.

With this morbid predisposition upon me--imagine me exposed unexpeetedly to the fatal atmosphere of a siek-room in whieh lay a dying man, as he devoutly believed,-a Land-steward-strieken with influenza, eaught upon my marsh: imagine the reports, the leetures, the death-bed warnings I had to sit and listen to, about this blessed farm! He deseribed it as you would a pestilenee; a terror to all around it; it must be eured (or killed?) not for its own sake, but as you would treat a rotten sheep, or a truss of mouldy hay. It was painful, yet ludierous, to hear him, for he talked like a dying man of a bad ehild - that would "be sure to eome to harm some day or other." What on earth was to be done? Agrieulture was not royal then-there was no 'Society's Journal,' no mottoladen buttons publishing the banns (for the first time) of "Practice with Science," no dear little weekly bonne bouehe of a Gazette, no July gathering of fat eattle and great men to look baekward and forward to, during the other months. All was dull, blauk, and eheerless, not to say "flat and unprofitable."

What was to be done? apostatize from all the pro- 
mises and rows made from my youth up, and take it in hand-that is, in a bailiff's hand, which certain foregone experiences had led me to conceive was of all things in the world the most out of hand, if that may be ealled so which empties the hand and the pocket too! Such secmed the only alternative: at first it was an impossibility-then an improbabilityand then,-as the ear of bearded Corn wins its forbidden way up the schoolboy's sleere, and gains a point in advance by crery effort to stop or expel it, so did cvery detcrmination, every reflection counteract the very purpose it was summoned to oppose, and, in short, one fine morning I almost jumped a yard backward at secing-my own name on a wagon!

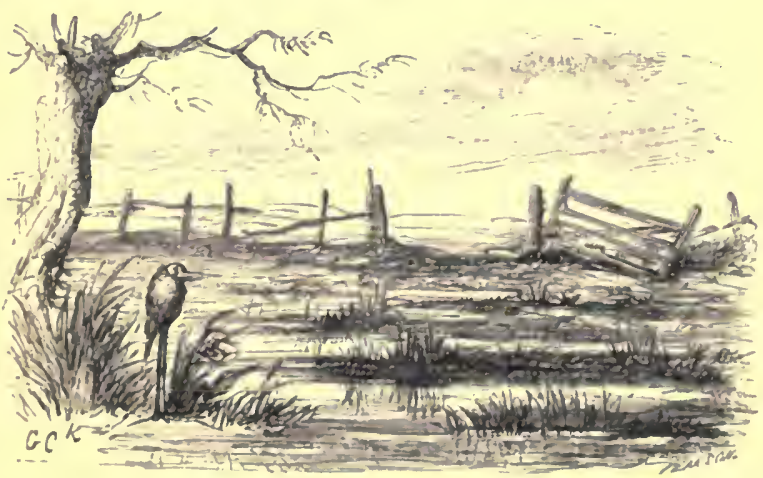

A Sketch-introductory. 


\section{II.}

\section{THE 'DEVIL-ON-THREE-STICKS.'}

There is an old saying that 'Fools build Houses for' wise men to live in,' a proverb which, whether applicable or not to Farms as well as Houses, probably receives about as fair an average of direct verification in the course of each man's individual experience, as any other of those mystcrious morsels of traditional truth which are handed down from each generation to its successor, like faëry money, Gold in the girer's, Dust in the receiver's hand. The young experimentalist in Brick-and-mortar, with a shake of the head not unworthy of the Elizabethan statesman (whose posthumous fame has owed so much to that outward symptom of plethoric wisdom), admits the general and antecedent truth of the motto which might be scrolled up over so many a splendid door-way: he does not doubt or deny it, not he! it is not to disprore its 
general, but to parry its particular application that he purposes: it is not to invalidate the truth of the rule as against man, but to prove it by an exeeption, in the ease of one individual of the species that he knows of. And the clear rectangular peneil-work, and the softening shades of the brush of the aceomplished artist-architect do their work upon his eyes, like Vanity reflected in a mirror, as he beholds (on pasteboard) the 'Splendid Elevation' and then reads with delight in one corner of the sketch, beautifully printed in Indian ink, the 'exeedingly moderate Estimate.' Such is "the taper that has lighted fools" each on his solitary track out of the beaten high-road of old Experienec, leading them on by the marsh-light hope of individual exemption from the Common Lot. And old men shake their heads and only smile, at the sallies of youthful arrogance that rise and break in succession upon the shore of life, and need no reproach but that which their own sure ebly will bring with it.

And so they felt, and so they looked on me, in the autumn of - no, I dare not say how long ago! - when the arrival of load after load of Draining-tiles gave parish notice of the attempt to drain what Antiquity had pronouneed undrainable, sinee the Deluge.

But why can't it be drained? asked Greenhorns. 
Beeause there's no Fall! replied colleetive Wisdom. Has it ever been tried with a Spirit-level?

Now this was not a fair question. Spirit-lerels (if they had any meaning or existenee at all) were unintelligible mathematieal-looking instruments of purely professional nature, only seen (if ever) in the hands of road-surveyors' assistants and people of that sort. They had nothing whatever to do witl farming. The question was unfair : it eontained an ambiguous term.

Pieture to yourself, however, the following conelusion from it. A bleak foggy November day: a long rambling spaee, marsh or meadow, as you might ehoose to eall it, of some twenty aeres in extent, and about the third part of a mile in length, with a narrow thick plantation of rushes, sedges, and brooklime, and sueh aquatie vegetation, threading its way in one long dank line from end to end, by sueh fantastie meanderings, that it looked as if the hidden ehannel of ehoked moisture it eoneealed had been making a eontinued series of experiments from time out of mind in seareh of an outlet; and after eenturies of struggle and disappointment, had at length arrived quite by aeeident at a eertain point, at one end of the meadow,-where you might sec a pair of high mudboots standing, or rather soaking, with a man in them, 
peering tlirough a telescope on three legs, as if he was watehing for the total eclipse of a small boy that is to be scen-gradually sinking-about fifty yards off, and clutching in his agony a tall staff by his side, figured as if for ligh and low water-mark.

Presently the Boots and the Teleseope, after various ineffeetual efforts and heavings, sueeed in striking their quarters; the boy, after sundry spasmodie struggles, to eorrespond, achieves the same exploit; and the same seene as before oceurs again some fifty yards further on, and again, and again, at the same intervals, until they reach the other end of the meadow, and eome plump upon tle banks of a marshy Pool some six acres in extent. On attaining this point, tlre telescope is suddenly shut up witl a triumphant snap; its three legs jump into one; the dripping shivering boy reecives a tremendous involuntary thwack on the back, and a Fall of Nine Feet is declared,-like a 'Dividend of ten per eent. and a Balarree over to go on with!'

Oh you primeval Carp, Pike, and Eels! you little thought on that day how deadly a fishing-rod, marked and measured ineh by inch, threw its shadow across your ancient domain ; little did your believed security dream of so new a monster, the angler upon three legs, 
that had measured the altitude of your downfall, and eaught you all, if not upon one, upon two cross hairs.

Old Fish or a New Farm? Snipes or Swede-turnips? Whieh was it to be? There stood but this question between the will and the way to let the Dry Land appear. And who knows what Saurian mollstrosities of a primeval age might be brought into daylight when this stagnation of waters was let loose, which had dammed up the moisture of so many broad aeres from time immemorial? sinee, little raised above the high water-mark of this pool, lay the subsoil of the whole farm beyond and around it; and the lowest point of this meadow was the lowest point of all.

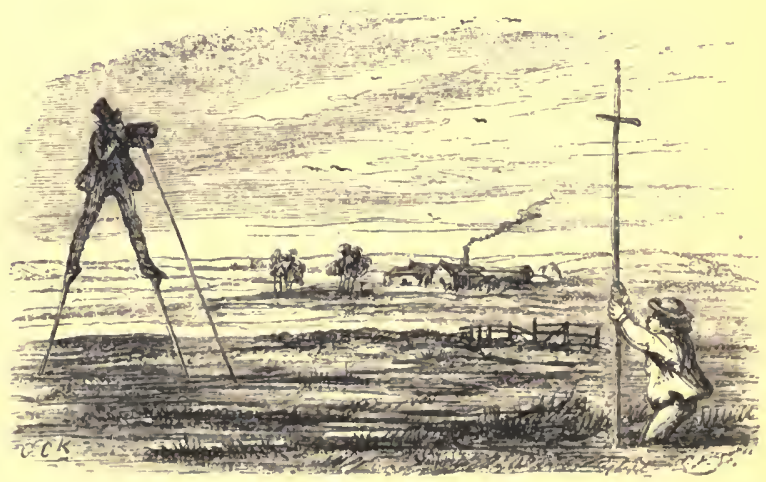

"Has it ever been tried with a Spirit-level" " 


\section{III.}

\section{A 'PRACTICAL' BEGINNIYG.}

It was urged by Mr. Brumel as a justification for more attention and expense in the laying of the rails of the Great Western, than had been erer thought of upon previously eonstrueted lines, that all the embankments and euttings and earth-works and Stations and Law and Parliamentary expenses-in faet the whole of the outlay encountered in the formation of a Railway, had for its main and ultimate object a perfectly smooth and level line of rail; that to turn stingy at this point, just when you had arrived at the great ultimatum of the whole proeeedings, viz. the Iron Wheel-track, was a sort of saving which erineed a want of pereeption of the true object of all the labour that had preeeded it. It may seem eurious to our experienees, in these days, that such a doetrine could ever have needed to be enforeed by argument; 
yet no one will deem it wonderful who has personally witnessed the unaecomntable and ever new difficulty of getting proper attention paid to the levelling of the bottom of a Drain, and the laying of the tiles in that continuous line, where one single depression or irregularity, by collecting the water at that spot year after year, tends towards the eventual stoppage of the whole drain, through two distinet causes, the softening of the foundation underneath the sole, or tile flange, and the deposit of soil inside the tile from the water eolleeted at the spot, and standing there after the rest has run off. Every depression, however slight, is constantly doing this mischief in every drain where the fall is but trifling; and if to the two eonsequenees above-mentioned, we may add the deeomposition of the tile itself by the action of water long stagnant within it, we may deduee that erery tile-drain laicl with these imperfections in the finishing of the bot. tom, las a tendeney towards oblitcration, ont of all reasonable proportion with that of a well-burnt tile laid on a perfectly even inclination, which, humanly speaking, may be ealled a permanent thing. An open ditch eut by the most skilful workman, in the Summer, affords the best illustration of this underground nischief. Nothing ean look smoother and more eren 
than the bottom, until that uncompromising test of aceurate lerels, the water, makes its appearanee: all on a sudden the whole secue is changed, the eye-accredited level vanishes as if some earthquake had taken place: here there is a gravelly Scour along which the stream rushes in a thousand little angrylooking ripples; there it hangs and looks as dull and heary as if it had given up rmming at all, as a useless waste of energy; in another place a few dead leaves or sticks, or a morsel of soil broken from the side, dams back the water for a considerable distance, oceasioning a deposit of soil along the whole reach, greater in proportion to the quantity and the muddiness of the water detained. All this shows the paramomt importanee of perfeet evenness in the bed on which the tiles are laid. The worst-laid tile is the measure of the goodness and permanence of the whole drain, just as the weakest link of a ehain is the measure of its strength.

But this of course was all theory, and theory of comrse was all nousense: my practical head-drainer was qunite of a difierent way of thinking, as his morlus operandi will exhibit. The morning after he had commeneed operations I found him hard at work cutting a drain, abont eightecn inches decp, laying 
in the tiles one by one, and filling the earth in over them as he went!

The field I had begun upon was very large, and very flat; and in order to inerease artifieially the fall, I had ealeulated so as to make the drain eighteen inehes deeper at the mouth than at the tail. I might as well have ealeulated the distanee of a teleseopie star.

"I've been a-draining this forty year and more-I ought to know summut about it !"

Need I tell you who said this? or give you the whole of the eolloquy to whieh it furnished the epilogue?

I had begun, something in this way-"Why, my" good friend! what on earth are you about? Didn't I tell you to lay the drain open from bottom to top, and that not a tile was to be put in till I lad seen it, and tried the levels?" \&e., \&c.

Old as Adam - old as Adam was the whole dialogue -it is idle to go through it-Coneeit versus Prejudice - the ignoranee of the young against the ignoranee of. the old-the thing that has been, and will be, as long as "the sun and the moon endureth." It ended as I have said.

"I've been a-draining this forty year and more-I ought to know summut about it!"

Here was a staggerer. Amongst all my ealeulations 
to think that I should never have ealeulated on this ! I had seen the commander of a noble steamer with one parenthetical point of his forefinger (eaught in an instant by the helmsman) veer round a ship of a thonsand tons burthen; I had seen the practical astronomer, with an infinitesimal touch of the direeting serew of the telescope, bend his searehing gaze millions of miles away from its first position; I had seen the mill-owner, with half a nod to his foreman, stop in an instant the hurly-burly of a thousand wheels while he explained to me, in eomparative quict, some little matter of new invention in the earding of the rough wool, or the rounding and hardening of the finished 'Twist. I had seen enongh of the empire of Mind over Matter in many forms and shapes, by sea and land, to make me the deroutest of believers in modern miracle. Under the quiet seduetire brightness of the midnight lamp, I had revelled in the mysteries of Number and of Form; and in the working realities of daylight I had secu and stood witness to the application of those apparent mysteries to the most beantifully simple proeesses in the produetion of ordinary and universal articles of human want. It had furnished me no new or diffieult gratification to level and ealenlate to an inch, the amount of Fall to be obtained upon a field, 
which without this preeaution might indeed be called, as it had been ealled, undrainable; and here I was, fairly planted, at the first onset. Every inch of depth was of real value at the mouth of so long a line of drain. "Three feet deep at the outlet" was the modest extent of my demand; and there I stood, watehing the tiles thrown in pêle-mêle to a depth of eighteen inches, which I was given to understand was 'about two feet,' with as eool an indifferenee to the other foot, as if Two and Three had been reently determined by the common assent of mankind to mean the same thing.

'But I must have it three feet deep !'

'Oh it's no use: it'll never drain so dip as that through this here elay!'

'But I tell you it must be! There ean be no fall without it.'

'Well, I've been a-draining this forty year and I ought to know summut about it.'

From that momert I date my experienee in the trials and troubles of farming: at that instant my eyes began to open to the true meaning of those 'practical diffieulties' which the minitiated laugh at beeause they have never eneourtered them; and which the man of seience despises who has said to 
steam, water, and machinery, 'do this,' and they do it, but has never known what it is to try and guide out of the old track, a mind that has run in the same rut " this forty year and more."

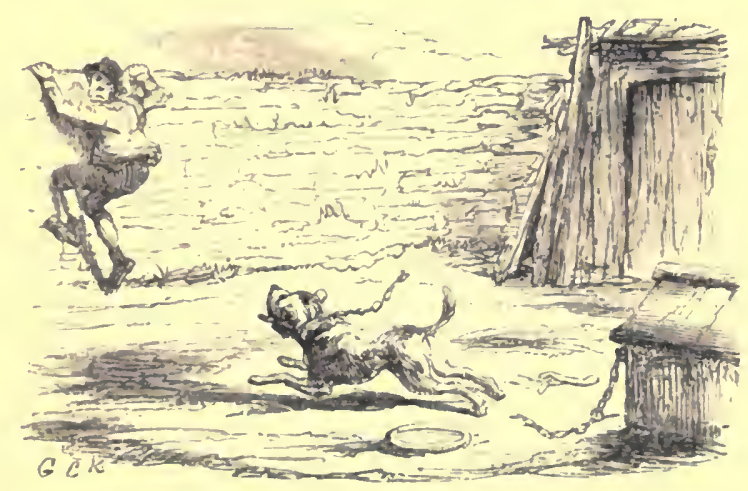

- "As the weakest Link of a chann 19 the measure of its strent th."- 


\section{IV.}

\section{A CONVERT,-AND A HERETIC.}

WE have heard-and a little oftener than is pleasant, -of victories gained in the Field and lost in the Cabinct. The eivil war that has waged so long, between the partisans of the deep and of the shallow drain presents an experience the converse of this. Long after peace had been proelaimed-upon papeland most of the printed authoritics had begun to pull together in favour of the deep drain-I say most, for even to this day a parting shot is now and then heard for the old system;-long after the shallow advocates had written themselves round to the other side, the battle was still waging fiereely out-of-doors. Truly may the Draining-tile be said to have "fought its way downwards ineh by inch." The benefit derived even 
A CONVERT, AND A HERETIC.

from a drain eigliteen or twenty inchés deep under the furrow which was still retained, was so manifest and immediate, that the very improvement itself prevented further improvement. A man who had shallow-drained one field, and found that even this did good, imagined himself furnished with a practical argument against deep draining though he had never tried it; like those who condemn books they have never read, on the authority of opposite-tlinking Reviews which they have read.

This was precisely the sort of reasoning that lay fast and strong in the skull of my old master-drainer; for master I saw he was determined to be. The evidenee of a hundred Spirit-levels would have been no answer to 'forty years' experienee' in draining and ditehing. Of this I was quite sure: so we were at a dead pass. One or the other must give way ' and be for ever fallen.' It was easy to wish him forty years' more experience -elsewhere-and 'good morning;' but this would be only entting the knot, and probably entailing another in sucession. Nec deus intersit nisi digmus vindice nodus! He was a good workman, and his authority over his men not a thing that it would be wise to shake, even had that been possible. A thought oceurred to me, a very bold thonght, all things consi- 
dered. I knew he hated the sight of the Level-that curious-looking thing on thrce stieks, - worsc than the old gentlcman that walks upon two. What if I could reconeile these two great opposing authorities by onc timely strokc-makc him Master-of-arts on the spot, before the cyes of all his men? Shorter and less earned degrees have been taken in the world. The opportunity was irresistible. I had it brought; adjusted it; and told him to look through it and give me his opinion of the Fall. If you ever saw a dog put his nose to a wasp's nest, you may form some idea of the mistrustful curiosity and hesitating aversion with which he brought his facc into close contaet with his arch-cnemy.

A long indeseribablc process ensued : a most detcrmined cffort to close the left eyc with the right hand - then the right cyc with the left hand-then a dead stillness, and a long fumbling breathless vicw of the world turned upside down, and his men standing on their hcads for the first time, in spite of the forty ycars' expcricnee to the eontrary: and then-

"Well I don't know but what you're right Sir: the Fall docs want a leetle easing at the bottom!"

The success was complctc. In half an hour every tile was uncovered. The men worked as mon work 
who feel justly proud of their eommander: he had arrived at the highest summit of his profession. He returned to them with doubled authority and importance; and the drainage of my first ficld was soon accomplished: not as deeply indeed-as we now call deeply; but deep enough, after the ridges had been twice east, to allow Exall and Andrews' subsoiler to follow the cross-ploughing a year afterwards, and break to pieces as obdurate a hearthpan as ever resisted the root of an oak.

'After the ridges had been twice cast:' how easy it looks in print! What a pretty little Example-farm would England-and what would not Ireland be,-if the Press could thus cultivate and eivilize!-if ploughs were printers' types and fields were paper-if bogs and fens and marshes could be drained like inkpots, and every drop that falls from Hearen-from which there falls not one drop-xo! NoT ONE Dnop-too much or too little-were apportioned to its proper place and task. It falls upon its proper place, and under that place lies its task, would but Man believe and act upon the hint, and do his part, his glorionsly privileged part, in carrying out, for his own benefit, the purposes of perfect Wisdom,-the indications of an ever-suggestive Handy-rork. 
'After the ridges had been twiee east'! Why, those seven words that lie so smooth on paper, eost me thrce times seven months of single-handed fighting against the 'Experience' of a whole neighbourhood. No hawk in a rookery ever got better beleaguered. "One down 'tother eome on!" was the one perpetual motto of the tonguc-task that awaited me, fresh and fresh, on every side, whieh ever way I turned. My own working-bailiff (et Tu Brute!) headed the attaek within the eamp-the traitor! while a ncighbouring clergyman led on the foe from without, evidently viewing the heresy in a serious light, and myself as a fit subject for an auto da fé. The eonelusion of our last skirmish was too good to be lost to posterity. I entered it rerbatim in my farm memoranda. Here it is.

' But tell me in eamest. Don't you mean to ridge up that field again!'

'No!'

'What, you mean to lay it small?'

'Yes!'

'In the name of Goodness! Why?'

'Bceause the Name of Goodnss-made it so!'

If I had suddenly assumed some denoniaeal form, and then, leaving a train of smoke and brimstonc, 
A CONVERT, -AND A HERETIC.

vanished, with a elap of thunder, from before the eyes of my eatcehist, I do not think his face would have assumed a greater expression of resourecless and complete astonishment than followed this extraordinary amouncement of the reason for a farming operation. Vainly had I attempted to explain in former conversations that when a ficld is effeetually drained, the furrows are underground, three fect deep; and that one of the great objeets of breaking the subsoil is to euable the water to go where it was intended to go, Dowwards ; that erery unevenness of the surface was a souree of deviation, and therefore of unequal distribution, of that rich food that falls from Heaven, -Oxygen and Hydrogen,-commonly called WATER : that on the best land farmed in the best way, furrows are aroided as a mnisanec and a loss, exeept as a mark for measure-work; and that the object of draining and subsoiling was-as the objeet of all Art is-to imitate Niture in her most perfect examples.

The paridox of yesterday is the truism of to-day. Gas-lamps light up towns and Great-Westerns eross the Atlantic, though Dary laughed at the one and Lardner at the other. And the prineiple of the Decp drain, which ten years ago the timid theorist dared not assert, for its wild and visionary secming, is now 
the substance of the 'Report of a Committec,' the last tautology of admitted facts that men endure, and having consigned to the charnel-house of the Blue Books, inscribe its epitaph in an Act of Parliament.

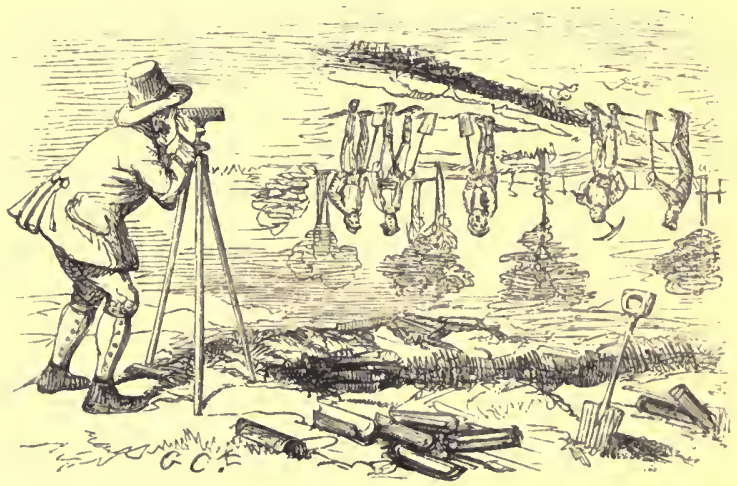

"In spite of forty years" experience to the contrary!" 


\section{V. \\ COMBLNATION AND COMMINUTION.}

Tиене are some incidental points of practice attendant upon the drainage of a field, which give very little uneasiness to a beginner, but which, like many of the other realities of life, gain foree with further experience. A blessed thing in its way is the untamed boldness of Youth. It gets done many things in this cautious ealeulating old world, which if not done then, would never be done at all, and whieh, whether useful for their striking goodness, or for their striking badness, afford equally profitable employment to that large and self-respected portion of the eommunity whose business and pleasure lies in eontentedly critieising the errors that others have made, in the elaritable spirit of

"the fiend that nerer spoke before, But cries 'I warned you,' when the deed is o'er." 
One of the points referred to, first presented itself to the notice of the Chronieler, in this wise.

'A queer lot this, Sir!'

'Well it is queer,' replied I, as the drainer threw out first a lump of blue clay, then a lump of red, then a horrible spadeful of white, then a dripping mass of ycllow sand, then a kind of grey grarelly conglomerate, that had puzzled the very pickaxe whose delicatc style of dissection had been brought to bear upon it, then a few spadefuls of beautifully-reined red marl, and then broke into a carboniferous-looking bed of black peat,-and then-but let the old drainer christen it, for my heterology is exhausted.

'A Queer Lot, this, Sir! What shall I do with it?'

I stood for a moment dramatically silent, working up my courage to a great effort. Out it came at last.

'Let it be spread over the land!'

- He was just raising his face to look up in mine. I knew what was coming; I eaught one sight of his mouth serewing into an agony of eontortion, as the idea loomed painfully, by degrees, upon his jereeptions. I waited for no more, but turned quictly round, trying to stifle a fit of inward laughter-not at my own 
words, but at the effect I knew they were producing; and walked away. I turned once only, and saw him leaning on his spade, and looking after me. I ean give you his soliloquy, for it was written upon his attitude, like the lettering of a picture.

'Well!-If that don't beat everything!'

A blessed thing, in its way, I say again, is the untamed boldness of youth. There was not a full-grown 'practical farmer' within a ten mile circuit of the spot where the old drainer stood on that day, wrapt in screre amazement, who would not have thonght it as much as his fair fame was worth to give that order. Nothing but the ineonecivable daring of pure unmitigated Theory would have ventured its eharacter upon such a throw. Now for the explanation.

Upon all wet thin cold clay soils, the wisdom of antiquity has long established that you are only to plough three or four inches deep; that you are to ridge up your lands into a certain round-backed shape which the rain may run off, as it would from an umbrella, or the roof of a house; that you are never to eross-plough, or otherwise disturb this consecrated form into which the earth's surface has been once-for-all moulded, but to kecp scratching it, 11) and down, shallow enough to insure a seed-time by 
having a dry surface two inehes deep, learing the furrow, and about a yard on eaeh side of it, as the perpetual ehannel or bed for water or ice in the winter, and baked sterility in the summer; that if anybody dares to mention to you anything about that mysterious abomination called the THE subsoIL, you are to serew up your mouth, shake your head and say

'It won't do to bring up that nasty stuff!'

'But don't Gardeners do it sometimes?' I one day ventured to ask, with ehild-like simplieity, in reply to the established doetrine.

'That's a different thing: Gardeners aren't "praetieal farmers.",

'But don't the roots of Plants grow dowywards in a Field, as well as in a Garden?'

I don't know how it was, but that provoking question always brought the eonversation to an abrupt close. I never eould get beyond it. It stuek in my own throat and everybody's else, like Maebeth's Amen. Left alone at last to my own ignoranee, I dropped deeper and deeper, day after day, into a state of eonfirmed Theory. I got strange notions into my head, that, as two negatives make an affirmative, perhaps two bad soils might make one good one, and three bad soils, a better still, and four bad ones the best of 
all! and when I saw the old drainer throwing out those lumps of many-coloured Clay, and Sand, and Gravel, and Peat, it was really too much for me. The monomania was irresistible: and the old fellow must liave known it; for at the very moment when the paroxysm was at its height-just when the extravagant thought was flashing across me that though everybody declared nem. con. that it was bad, SомE Oxe had pronounced it Goon-just at that very moment of weak hallucination, the old Lueifer, smacking his lips in an odd way of his own, looked up temptingly in my face, with his question, 'A queer lot, Sir! What shall I do with it?'

Bluc and red, yellow and grey, white and black, stiff and loose, gritty and waxy, cohesive and repellent, soft and hard-there it lay before my eyes, my precions subsoil in all its Protean variety of colonr, texture, and consisteney; there lay the raseally substratum that had pulled down strong men one after another who had tried to grow erops over it, exposed at last and bronght to daylight like an unearthed fox ; there it lay, dripping away its long pent-up moisture down the narrow ehamel that led to the newly opened outlet, through that same long meadow afore-time celebrated in this Chroniele; reminding one of a fallen 
foe bleeding out life and mischicf at last and for ever. The impulse of pent-up theory was irresistible. 'Let it be spread orer the land!'

And so it was. And a very curious-looking field it made for the livelong Winter that ensued. Wise men came from all the quarters of the eompass to look at it. Some of their remarks and questions were very flattering. "Where had I purehased my Winter topdressing? as they should like to buy some at the same shop, cost what it might." "What winter erop was I growing so earefully under the variegated carpet?" To all which I answered with becoming gravity, and modesty of my own merit. Some of the remarks being of a more mysterious character I entered in $\mathrm{my}$ Farm Journal for future explanation and experienee; such for instance as that of an old gentleman who shutting one eye, (I suppose it was a habit,) told me with great blandness of mamner that I had "put my foot in it." (What could he mean?) Another was so full of general good wishes that he "wished I might. get it" more than once; which I thought all the more good-natured as he did not even stay to particularize what crop he alluded to as wishing me to get, or how much per acre. But of eourse I eivilly 'wished him the same,' gently shutting one eye, as I saw it was the 
fashion, and had such a pleasing effect: at which, being an old friend, he performed the ecremony of inserting his second finger between the fourth and fifth rib of my left side, and informed me, with a smile, that "he saw I understood chaff", to which innocently replying in the affirmative, I added, for reason, that I had a great demand for it of late amongst my friends, and found it an useful commodity in farming. Such are the dark and recondite passages presented by my journal of that winter, which I offer for the information and guidance of all those who may purpose trying novel experiments unsanetioned by the established practice of their respective neighbourhoods; merely noting that there are some things besides the soil, on this earth, which require a little tempering, and pay well to a man's peace of mind for being donc quictly and ncatly, withont haste or heat, - vet smartly withal.

Spring came at last: bcantiful Spring! that fills the old heart with youth, and softens down to a nore genial and hopeful tone the frosts and snows that reign within, as without, through dreary winter. Certain reports respecting the field which had been drained, and so curiously 'top-dressed,' had from time to time altered the curnent of opinion that had hitherto run 
so strongly all one way. The under-wagoner had told somebody in striet eonfidenee that the snow had disappeared on that field much sooner than from any other. This had been repeated in equal eonfidenee from mouth to mouth, with the addition that all the elay had 'kieked down to ashes;' but what topped everything was that before even Beansowing had begun, the 'motley elose' was reported 'as dry as a bone!'

The Harrow is eertainly not the most ingenious or perfeet of agrieultural implements; but never was a more surprising feat performed by any, than was witnessed one fine morning early in Mareh, when it was ordered over the field afore-mentioned! Down went the elay, sand, peat, and everything else,-

"Black spirits and white, Blue spirits and grey, Mingle, mingle, mingle. Ye that mingle may !"

And 'mingle' in truth they did, into as free healthylooking a soil, as fresh and as mellow as if it had never lain underground or been out of the sunshine. With every turn of the horses, better and better it looked and worked. An inereasing elastieity of movement seemed to pervade men, horses, harrows, soil, 
and even the very atmosphere of the ficld. Before the Work was half done, Tneory and the Chronicle were at a premium.

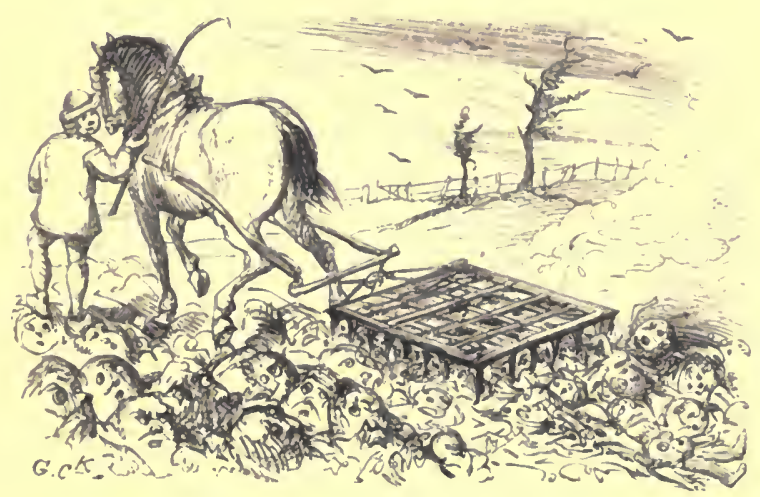

" Y'ngle, mingle, mingle,

ic that mingle may ${ }^{+1}$ 


\section{VI.}

'CALX'-AND RECALCITRATION.

A LoNG long time-what a dreary time-is Winter! Well may all Christendom have lent its comfortable efforts through ages past, with a long and a strong pull and a pull altogether, to give a point and a zest, and a time of almost legislated conviviality, in the Christmas fire-side and good fellowship, by way of indoor barricade, a sort of jovial rebellion, against the long despotism of Jack Frost! It is hard to convey an adequate idea of the bounding pleasure with which -after watching, month after month unehanged, the rugged uncouth results of that novel piece of autumn workmanship lately described - I saw at last the wholesome-looking combination of such a heterogeneous varicty of carths that had lain icebound, as if for perpetual and stereotyped ugliness, now melting down under the genial influenees of Spring, and that blessed 
pair of harrows, into what old Evelyn must have especially had in his eye when he talked of ' a roscid and fertile monld.'

'Easy work it is to preach about farming experiments,' thonght I to myself, as I wandered in the gloomy evenings of December and January, amongst the square elods that lay exhumed upon the surface of the ficld, with the spade-mark inseribed in frozen obduraey upon their sides, like the bloeks in the quarries of Syracuse dated with the tool-marks of twenty centuries ago! 'Easy work to preach experiments, that take a year to make, and another to judge of, and another and perhaps another still, to see the whole result of,-to men whose "threescore years and ten" were hardly a sufficient Lease in whieh to serape together a dozen faets beyond what their fathers knew! A pretty homily upon Lesses there lies in these elods that have been keeping sentry here these three months, while the Manufaeturer has worn a steam-engine from new to old, and the Trader has turned over half his eapital, and briskly put in a fresh stoek of 'Spring Fashions.' In the name of Common Sense, that useful ' raw material' which England has as plentiful as Coal and Iron,-what dead carcase has been chained to this living Art of Arts to elog its progress and to rot its vital powers, by adding the curse 
of Insecurity of Texure to its already arduous and time-and-paticnec-nceding problems! If it bc Mind that aets upon Mattcr, what is it that acts upon Mind? Surely Motrve and Interest, and that Assurance of Results, whieh the most ordinary prudence demands, and the most buoyant energy feeds upon-or dics.

Well may a bold expcriment startle minds whieh harc been drilled into the habit, because into the neeessity, of contracting every prospect, cvery outlay, every mental conception, within the compass of an 'Agreement for a ycar!' If there is an attributc whieh morc than others marks the distinction of the human mind, from that of the lower animal crcation, it is that it looks forward: if therc is an art that more than others demands the powerful and prolonged exercisc of this faculty, it is agriculture: if therc is a thing which adds force and method and precision to this faculty, it is-Education. Does the pen need to draw the conclusion? Can the reader of 'Sermons in Stoncs' deeipher no Leases in Clods, no schools of instruction in "Calx, Silcx, and Alumen?"

Winter howcver, like Adversity, has a surprisingly improving influcnce upon-things made of Clay. As each little thaw, towards spring-time, camc and went, the gradual process of granulation had broken 
down the onee wet and recking spadefuls into the form of dry loose Mole-heaps. As the tines of the harrow jumped and daneed freely through the mingling mass, what a changed appearance was left behind! a dry rich eartly seent, sweeter than the breath of an Orange-grore, or the evening incense of the hay-ficld, rose gratefully up to meet the fresh morning beams that shot their influenee for the first time on the new face of an old field; the busy gossamer drew its glittering net-work from point to point in a thousand geometrieal forms orer the levelled surface.

'Well! I nerer thought to see it look like this! I should think anything would grow here!'

Such was the remark I overheard. I suppose it eame from one of the horses: they were the only living things present that were not pledged to an opposite opinion. The observation, however, if illfitting was not ill-timed: it ehimed in with the thoughts that were tumbling orer each other in theoretical eonfusion throngh the brain of the incurable Chronicler. What would hare been thought of him had he dared to utter them aloud, as they eame and went in this strange fashion-

'The Protoxide into the PERoxide! ha! a beauti' ful change that. Clay, Sand, Peat,-and Marl too! 'a goodly eompound. How is it that a sort of instinct 
' seems to anticipate the conclusions of Seicnee-that 'the mind outstrips the page, and one's assent to ' each proposition seems paid in advance, almost be'fore it falls due? Is Science intuitive? then why is 'it MODERn? Why have eenturies upon centuries' sixty centuries-passed, and none till now! Why ' now? Could Licbig answer that? I'm afraid even 'his 'Quantitative Analysis,' his grand discovery (for 'so it almost seems), of the magie residing in those 'words, 'Numero, Pondere, et Mensurâ,' would be 'baffled to resolve that problem.

'This field for instanee! they never thought to see ' it look like this : now, could they answer the question '-What does it yet want?-Yes! the instantaneous 'reply would be Lrme. 'Why?' inquires 'Theory; " Beeause it would sweeten it'-would be the answer. 'But why? Theory again asks. Praetice is silent. 'What? silent, after sixty ecnturies of 'Experience!' 'Can nobody give us an answer-the truth, and the' 'whole truth of the operation of Lime upon soils?' The Chemist attempts an explanation.

'Its effect arises from its avidity for combination; 'it searches out free acids, as a ferret does a rat, and 'instantly closes with them. Sulphurie, phosphorie, 'silieic, nitrie, humic, and last not least, the 'Great 'Dissolver,' Carbonic aeid: all these it makes known, 
' by seizing upon them and becoming their base; thus ' disintegrating as it were, and reconstrueting the ele'ments of the soil, and exciting to a new action the 'sluggards of Nature wherever they are lurking.-It ' is the Composer and the Decomposer, for nature ' eannot suffer either process, but fertility must fol'low: re-composition (growth) has begun ere decom'position is over: does a latent atom of organie mat'ter stand inert for one instant? it is at him, like a 'Policeman,_- Come! kip moovin!'

But is this all?-is this half?

Well may the 'Incoming Tenant' ask " How far is it to the Lime-kiln?"

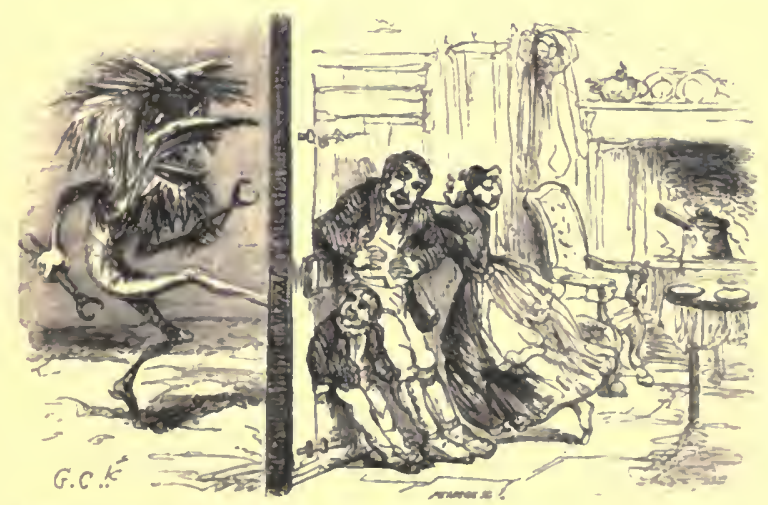

"A sort of jovial rebelion against the long despotism of Jack Frost." 


\section{VII.}

'EARTH '-STOPPING.

Axongst the various ehanges upon the aspeet of a Farm neeessitated by modern practice, there is none which eauses a greater degree of eonsternation in the immediate vieinity than the removal of the Hedgerows. There is a kind of time-lionoured reeognition and respeet aceorded to these huge 'mounds,' four or five feet high, and broad in proportion, with the running aceompaniment of jungle sprawling at its pleasure into the plough-land alongside, which it goes to the very heart of the labourers themselves to deseerate, or reduee to the regulation-standard. It is all very well under the glowing eandle-light, with the map of your farm spread out before you, and its hedgerows redueed to mere lines of sepia or lamp-black, to eut and earve, at your will, ten or twelve large square eomely-looking fields out of thirty or forty unac- 
eountably-shaped rhomboids undreamt of in the hardest book of Euelid, and then to go and dream the realization of your symmetrieal example-farm, the wonder and delight of ardent agrieulturists : but what a ehange comes over the spirit of the dream, when you mizzle ont o' doors in the foggy November morning, and come to a dead stand-still at the tangled side of a fonce (Bless me! why it looked nothing on paper!) which has furnished the talk of many a Hunt-dinner for some centuries past, for the splendid leaps and the splendid 'purls,' it has given rise-or giren fall-to. Its height-its cnormous widtl_-its insurmountable impracticable look altogether, require an eye quite as stearly and a heart quite as firm as the liunter's, to take it.

It seemed like saerilege,-indeed I felt self-convieted, at the first daring onslaught upon these giants of the olden time. I was obliged to 'take a run at it' mentally, as it were, as many a man and horse had before done bodily and in the flesh; and stuff my cars against the covered reproaches of the workmen.

"Famons bank for ralsbits, this licre, sir! I've know'd twenty couple killed in a day out of it, in my time, when Squire___"

" $\Delta$ h! well-never mind"-quoth I, sorely and 
interruptingly: "but what's that-what have you got there?"

"This, sir? Lor' blesh ye! this is the earth where that ould vixen lived as gave you such a run last winter: I've know'd a litter o' seven whelps reared in this hole, an' heared 'em a yelping an' howling o' the summer evenings as if the' wondered when upon airth cub 'unting 'ould begin!'

This was the elimax, usually. No martyr ever suffered more than I used to carry home to breakfast imo sub pectore, by way of travesty to my over-night's imaginative enjoyment at the paper-prospect of large inelosures and unimpeded plough-shares.

But the day of compensation eame at last; and with it eame my first diseovery of the extraordinary sheep-sightedness of spade-and-mattock-wiclding humanity. Not till the fenee was elear away, bank, thorns, pollards, ash-trees, rabbit-holes, fox-earths, and all, did I ever hear the exelamation-

"Well! this is a wonderful alteration to be sure; why, I never thought to sec it look in this way! It's quite a beautiful ficld now !'

'One eheer for THE MAP after all!' quoth I to myself, as at next eandle-light, down I sat again orer the bird's-eye view of aeres which I now began to find 
were trodden by bipeds and quadrupeds with abont equal pereeption of their plan and bearing. Who wonld be without an aecurate Map of his farm, who onee knew the eumulative triumphs that it brings of skill and headeraft, as larishly accorded in the end, as denied in the outset, by the gregarious juries who sit in judgment on his aets?

Down went fence after fenee! each with preciscly the same prologue and epilogue of blame and praise: for all the snecessful issues in the world nerer stop or stay that rampant 'inconvertible' thing, criticism ; that battery of inextinguishable pop-gums that is never sileneed or taken by assault. Down howerer went the fences notwithstanding: and ecrtainly, withont reference to any of the more subterrancous improvements, of drainage, eultivation or otherwise, the mere aceession of business-like appearanee to the farm when denuded of its miles of jungle, was what Dame Quickly wonld eall "a thing to thank God npon."

It would be a diffienlt but an interesting task to make ont a ealeulation of the economy per acre, of the riddanee of these hideons and nseless strongholds of roots, weeds, birds, and rermin that aftliet the farms of merry England. Inproduetive in themselves of anything that is good-for eren the tmuber 
they eontain is very rarely so-they are equally an obstruetion to the plough that toils for bread, and the eye that wanders for beauty. Far be it from the old Chronicler to depreciate the "tangled copse" or the "boundless contiguity of shade" that gilds the early remembranee of some, and the imagination of all; that lives in the tasteful pages of Evelyn and Priee, or in the 'charming bits' of Wilson or Nasmyth: but where ean be the pietorial or moral beauty of a great erooked artificial mound surmounted by a dead fence serrated into gaps and 'raspers,' or at the best, hogged into dreary uniformity that euts the blessed landseape from the eye, by a man-made barrier of stakes and 'witherings.' "'Take away the eurtain that I may see the pieture" might any mortal say, who from his first lesson in Geography had learut that a man six feet high has a sort of physieal right to a panoramic horizon of three miles on this round globe of ours, even in a distriet like mine where not a hill was to be viewed.

To be sure there is one rather formidable consideration-the hedge-pheasant-shooting-' beating the outsides' - that pleasant Oetober skirmishing that preeedes the eoming up of the heary artillery at Christmas; but is it not rather dearly retained, when land is 
being cut up for Railroads all round us, at two or three lundred pounds the aere, and searecly a vestige or margiu left to inclose for the "more more" ery of an increasing population?

It is at the least, a consolation to think that these huge banks have no preseriptive right: that when Cowper told us "God made the Country" he did not mean to deny that man made the hedgerows, or the conclusion that what he had raised up, he might pull down; especially when it is discovered, as each may prove for himself, that the Thorn grows much better on the level.

No! let the Park and the Pleasaunec have their raried and picturesque alternation of bush and tree and green-sward, of broken masses winding glades and labyrinthine glens; and let the forest have its leafy sereen, its deep and devious mysteries of light and shade; but let the field of the husbandman have that beauty of its own-the charm that Nature delights to throw over ererything in proper turn and place. The waving and extensive Corn-field, the decp rich winter-verdure of the tumip-erop, the dark and mellow surface of the fallow, owe little of beauty to the net-work of intersecting barriers that arrest at onee the plough and the prospect, and earry 
a runuing nest of robbers, like earth-works of the enemy, through the fair fields of human skill and labour, and saerifiee at onee the food of man and the profit of the grower.

It is the eye of Prejudiee, not of Taste that sees Beauty absent from Utility. Even in the flattest distriets, eren upon 'the Clay Farm' itself, there is an undulating outline, a morsel of the varied profile of our mother earth which never revealed itself to the eye until those impediments were abolished, whiehlike Ignoranee-make us mistake for a dull straight line that whieh is only a part of The Great Circle.

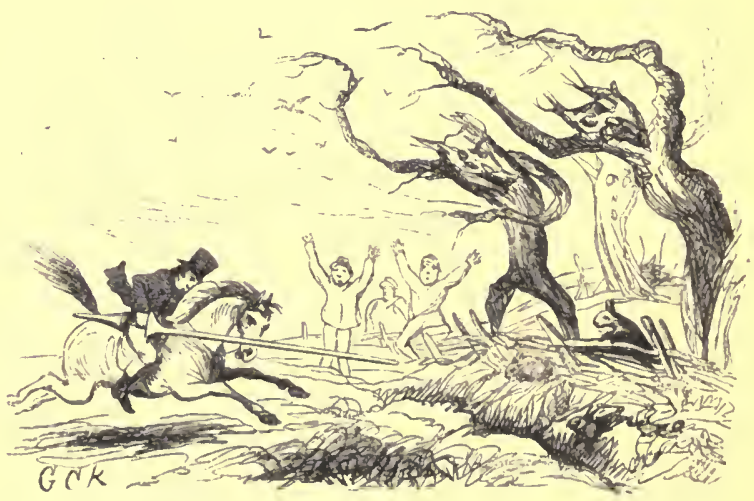

"Down went the Fences, nctwit hstanwne." 


\section{V111.}

'TRUTH AT THE BOTTOM OF A'-MARL-PIT.

Amovgst the legaeies which the wisdom and labours of antiquity had bequeathed to the Clay Farm and its cultivators, one of the most eurious and truly puzzling was a quantity of Marl-pits. In crery field of five or six acres there was a great yawning 'Pit,' decp' enough to drown the weathereock on a ehureh stecple, and wide enough to aecommodate the chureh as well : and when the broad hedgerows were stocked away, (and, in good truth, my two first winters made strange havoe amongst those mounds of aggravating wilth and erookedness), nothing ean be imagined more absurd than the effect of these deep wounds diselosed upon the bosom of mother earth, lying thick and threefold in the fields, as now enlarged to an average of about twenty acres each. What on earth-or 
rather under the earth-was to be done with them? Favoured oeeupiers of the valleys and meadow-lands of our Island, you hardly know what I mean! lend me your attention then for a moment, while I read a short ehapter from that Geologieal Eeonomy which experienee and the elays have taught me.

Amongst the manifold varieties which Nature offers to the mind and gratitude of man, not the least benefieent and beautiful is the Undulation of the earth's surface. How little do we value gifts and blessings that are quite familiar! Imagine for a moment a flat earth with no variety-no inelination of outline; no hills, no dales, no uplands or meadows, no running streams or rivers, no tufted knolls or winding dells, no 'gradients,'-but one vast unruffled surfaee, like the sea in a dead ealm, or the Great Desert itself: and then imagine one thing more, a thing which you are in the eonventional habit of eonsidering one of the greatest of agrieultural blessings-a free percolating subsoil, underneath this vast monotony of surfaee, sneking down every drop of rain as it falls, and preserving not the value of an eggshell of liquid for man or beast to slake his thirst withal. What would you have given, under sueh a state of things, for 'Two Hundred and Fifty aeres of CLAY subsoll? Would 
you not have regarded such a means of retaining some of the moisture given by the elouds, almost as a special providenee!* Too much water-too much ANYTHIS however good-is always an ineonvenienee: but which were best-too much or none at all? Now this is precisely the thought that used to oecur to me (marked 'private') whenever some visitatorial geologieal new-and-improved-agrieultural stranger bestowed an overlose of sublime pity upon the affliction of elay that lay underneath my Flat Farm.

'A pretty business you would have made of it,' I used to think as I heard them glorifying the merits of a free subsoil-' if you had had the ordering of it! Hearen be thankel, a Wiser Hand than yours has had the management of these things, and has, for the most part, confined the sandy subsoils to the neighbourhood of rivers and ruming streams. Put your-

* "Levelled of Alps and Andes, without its Valleys and Ravines,

How dull the face of earth, unfeatured of both beanty and utility :-

Praise God, creature of earth, for the mercies linked with seeresy :

Praise God, his hosts on high, for the mysteries that make all joy."

[1. F. Tupper. 'Proverbial Philosophy.'] 
self on the top of a Salisbury eoach, some fine, hot, midsummer's day, and take a trip across the Marlborough downs, and then you will see what it is to have a thirsty ehalk subsoil upon high land, "where no water is": and then you will see reason to conelude that there may be some problems even more puzzling to deal with, amidst the infinite variety of earth's surface, than a elay subsoil.

As late as the middle of the fifteenth eentury,we are told by an old writer* on husbandry matters,"Lime, even elose to the kiln, was dearer than Oats ;" an odd comparison, yet foreible too; and as roads were then not exactly what they are now, it is easy to see that our forefathers had reason good for making the Marl-pit do duty for the Lime-kiln. $\dagger$ The inorganie matter that was jogged away from the Farm with erery bushel of wheat or pound of butter or cheese that went to market, did not eome back again from the elouds. They soon found out that. Human

* Whitaker, Hist. of Craven, p. 324.

+ It is worth remark that Sir Anthony Fitzherbert, Chief Justiee of the Common Pleas, whom by the bye I hardly deserve to quote, seeing he ealls himself " ancxperyenced farmer of more than 40 yeares") in his 'Boke of Husbandrie,' published in 1523, frequently mentions the employment of Marl, but in his list of Manures, ete., omits Lime altogether. 
instinct and experienee had diseovered the gradual loss of something, which neither rain nor sunshine nor even the farm-made manure, deprived of these elements, could restore,-long before Dary or Licbig were born, or Sulphates and Phosphates had becn christened: and henee the Marl-pits.

Curious and awkward relies of a bygone day they were, dotted about orer my farm, and looking more numerous and unmeaning than erer, after the enlargement of the fields, and the straightening of the few fences that were left. Load after load of clay from the drains, and some hundred butts of felled trees, and useless pollards from the ranished hedgerows, were cast headlong into their voracious depths : but enough yet remained, and will long remain, to tell of the enormous labour that must once have been expended in exearating a manure more costly in its application than the Guano which from the far islands of the Pacifie Ocean, conveyed by sea and land, thousand upon thousand of miles, finds its destination at last upon the field of British husbandry.

Well might the farmer of the olden time bore like a licll-sinker, at whatever amount of labour, for aught in the shape of a restorative, when "the diffienlty of communication arising from the nearly 
total want of roads preeluded the interehange of commodities; when goods were earried on pack-horses, a mode of eonveyanee which necessarily prevented the conveyanee of bulky articles to any considerable distance. The price of grain was thus materially affeeted, for while some distriets were suffering from seareity others were overflowing with a surplus, and it was enhaneed beyond its real value in one place, while it sunk below it in another: just as at the present day, in many parts of Poland that are distant from great towns, and without water eommunication, the value of the erops is so diminished by the expense or impraetieability of earriage on ill-eonstrueted roads, that cultivation is generally neglected."*

In a word, cheap labour and dear carriage were the tools that dug those ancient marl-pits; and many a long and lonely reveric upon the ehanges that centuries have brought about, did they afford me,-after the last workman had whistled his willing way homewards, and I stood upon their dark brink with the sileneed field around me, and the evening sky drawing its noiseless eurtain overhead; till some peeping twinkling spangle refleeted in the water at my feet,

* Introduction to British Agriculture. U. K.S. 
warned me that the bright little sentinels of Heaven were taking one by one their wateh-posts, and beekoning me to follow the example which one weary toiler after another had set,* even to the very Plough that lay sleeping in its bed in the half-finished furrow at my side, as if nothing would ever more it again. And then through the still night air, as I moved tardily homewards, there would eome a sound-a strange sound which the diggers of those aneient marl-pits never heard by day or night. Was it a beetle or some other lazy inseet, homeward bound, that made that peculiar humm which secmed to thrill through the atmosphere, far away at firsttheis gradually nearer, and then louder and mole tremulous as a gust of wind brushed by - then fainter-and fainter still-and then_-gone! What was it? if the ear could measure miles, it might seem to have traversed some seven or eight, before it reached me. Oh! ye who tilled these ficlds and dug these marl-pits in the days of narrow lanes and pack-saddles, what would you have said to that Mail-Train that was flying like a meteor through the

* " et jam nox humida coelo

Precipitat, suadentque cadentia sidera somnos." 
night, upon its traek of polished iron, some seven or cight miles away; annihilating Distance, yet leaving SPACE undiminished; turming the widc-spread country abodes of men into one vast Metropolis of human Socicty, Mutuality, and Intelligence, not choked and dcadened by long rows of brick-and-mortar, like the dull changelcss man-manufactured Town, but open and frec and independent as ever, with carth and air and sky unpolluted, undescerated by the Throng; yet Man united by the elosest intercourse and sympathy with the marts of aggregated skill and progress in each Art and Science that instruets, cnriehes, or ennobles.

Despise not the Town, O man of gaiters, corduroys, and short-cut-away, whose face is stcreotyped into perpetual jollity by Nature's wholesome merry hand, whosc talk is of Swedes, Superphosphatc, and Red Lammas; nor do thou despise the country, O frockcoated, sleck-hatted umbrella'd Town-denizen, whose face is blanched and thoughtful, and mayhap a little wrinkled, and whose talk is of Priec-current, Scrip, Cargoes, and Consols. For you are each other's Customers and Brothers: the iron artery of locomotive traffic, and the clectric nerve of flying Thought has brought you into a new and closer bond of reciprocity 
'TRUTH AT THE BOtTOM OF A'-MARL-PIT. 57 and fellowship: it matters little at which end of the wire your place and life-task are appointed; your hearts and heads were east in the same human mould, and it is hard but such a tie as now unites their throbs and thoughts, shall strike out some results and combinations that you searcely dream of yet, from the twin realities of Agriculture and Commeree.

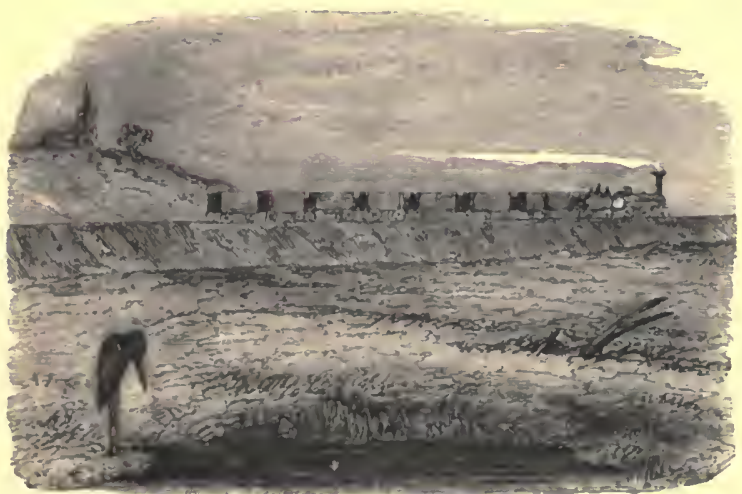

'The bright hetie sentmels of Heaven were takng one by on the: r watch-posts.' 


\section{IX.}

\section{'FALLOWS'-AND WHAT FOLLOWS.}

WheN the land is drained, and the erooked ridges obliterated; the useless fences stocked away, and the few that remain straightened; the Ash trees and old pollards grubbed up, together with all other timber that is neither useful nor oruamental; the awkward inequalities of surface redueed, by the spade as well as the plough; the Farm-buildings improved a little, and adapted for the better and roomier accommodation of a better and larger head of stock : and last not least, the House rendered habitable for human beings " both male and female"-when all this is done-and thanks to increasing Population, increasing Trade, and inereasing Intelligenec, such things are done, here and there, now-a-days; -it will in most cases be found that a considerable amount of 'Time, and of-something else will have been expended. But can it in 
truth be said that until this be done, the Plough ean ever start, with a fair ehanee? Does any one seriously believe that the employment of his farm-labourers for a few winters, in the execution (as mueh as possible by fairly-paid task-work) of these preliminaries, is a matter of supererogation or an unprofitable outlay? Suppose it cost $\mathbb{E} 10$ to the acre, and including all, we must prepare for such an average, is it so extravagantly disproportionate to the looked-for return in the shape of Interest for Capital as to execel the ordinary ventures of man in other branehes of industry? Is the abolition of the bare summer Fallow, of the half eultivated and therefore half produetive Headlands, of the eternal labour of hedging and ditehing, the depredations of birds and vermin, the everlasting turning of the plough and other implements of eulture, with time-losing, harness-breaking, and horse-laming, to correspond; the injurious shade and droppings of trees, the stagnating water, and the barren furrows, -is the immunity, I say, from all these and many other evils recurring not once, but every mortal year, and year after year, to the culd of time,-is all this to be borne, because of the dreaded outlay, (and is it a loss of the interest?) of $\mathrm{E} 10$ per statute acre? 
The question seems simple enough : yet after all is done, whether by Landlord or Tenant, or by both in one, there is yet one morc question to be asked before the answer can be prudently ventured. I do not mean the question whether there is a long Lease: that indeed must speak for itself: it is a question if possible more important than even that. It is a practical question; let us give it a practical elucidation.

It is one of the most expressive and meaning features, rather than a deformity, of agriculture, that it is full of exceptions and variations, and of what men call Disappointments. However good in their way broad principles, and laid-down courses of cropping or of treatment may be, experience soon teaches us that not only each soil, but to a certain extent eacl ficld, has its own independent eharacter and claim upon the judgment, which will not be wisely submitted to the Procrustean law of this or that succession of crops. Skilful management is at lcast required to coax a farm into the designed and fore-determined Rotation of four-course or six-course, or any otler course of husbandry; and to this end it is generally useful, and sometimes amusing, to inquire into the local reputation which almost every field will be foumd, on inquiry, to have established for itsclf. 
But when two or threc or four ficlds come to be thrown into one, in a district originally close-fenced, and where great varictics of soil are met with, this deference to the archoology of the land becomes rather puzzling to indulge and carry out.

Being bent upon the adoption, as far as possible, of the six-course shift, I had made it one of the oceupations of those valuable provisions of nature,-the long Winter Evenings, - to eut, carve, and contrive, upon the map of my farm, a division of the arable land into six principal ficlds. The task was not a very easy one. The inclination of the land being very slight, had to be studied with the greater eare; the fences that should remain were not always the best or the straightest; and that halfway house of indecision (so well known to all busy travellers on the highway of life), between making a good job at once, on the onc side, and ceonomy of labontr, on the other, oceasioned many a halting hour of doubt, during which Day and Night, Map and Land, alternately gave each other the lic, and took it back again, with that quick reciprocity and alternation, for which halfway houses, real as well as metaphorical, are not meelebrated in fact and fiction. We are told by the oldest of profane historians, that it was the national practice of the ancient Per- 
sians to think over every important plan twice: first, in the morning when they were sober, and again in the erening when they were-making speeches; and vice versa : and as decision and steady purpose, in the field, when the work is onee begun, is as useful, and almost as neecssary, to the Farmer, as to the Fieldmarshal; and as that exacting and important branch of the community-your neighbours-don't usually approve of your doings until they understand themor in other words, laugh at you, till you begin (or might begin) to laugl at them; it is emmently advisable, at least I found it so, to call a pretty frequent meeting of that privy-eouneil which erery man is Chairman of, who has got Daylight and Eyes, Candlelight and Brains, a Farm and a good Map of it. And if, $\mathrm{O}$ ! ardent and yet perlaps sensitive Beginner, you will take one word of adviec from an 'old file'-if onee you have eome to a determined vote and eonelulsion, after full deliberation with these fellow-couneillors, and after hearing all they have got to urge pro and con,--don't let anything or anybody dirert or modify your plan. Your experienee and mine will differ very mueh if you do not find more expense, and more regret, left belind invariably by an under-done than by an over-done joib. "The first expense is the 
least" in agriculture-and in everything else perhaps, with the old exceptions of Law and Matrimony.

'The first field which I had drained, and to whose chromicled history I must now return, was a tolerably reetangular result of what had formerly been two ficlds, and part of a third; and consisted, after its cnlargement, of about twenty-two acres. One half of this, that is to say, one of the fields as previously fenced, I devoted to a crop of Swedes-the first that ever had been heard of on the farm (and the last, in the opinion of all surrounding Wisdom, that erer would be); the other part, for reasons in which I suspect you would have aequieseed, had you seen it, I determined to indulge with its old but long-forgotten friend, a bare summer fallow, and with a dose of that same Lime, about whose ehemical effeets and influenees we had so long a soliloquy some time baek. Until the end of April all went on alike orer the whole of the twentytwo acres. Ploughing, senffling, and levelling were the order of the day, to the great scandal of the high ridges and their admirers; but on the ponderous and august entry of the clod-erusher (a new monster in those days), the first-mentioned half of the field took leare of the other, and as each clod yichled up its individuality under the potent arguments of that most persuasive of implements, the modern fallow went a- 
head of the aneient, and old Jethro 'Tull himself would have envied me the delight of seeing the work of eomminution and perfeet intermixture which its magie transit left belind it. Never was there sueh a sagaeious or relentless old tyrant in dealing with a elod, as this same Crosskill, for so it shall be named, and right deservedly. If he ean't erush it with his elephant foot, he takes it up secundum artem as a mastiff would a bone, and gives it a squeeze with his iron teeth; and if that won't do, why then like a bull he tosses it over, and gores it with the next revolution. Clever must be the lump that, after one or two sueh embraees, eseapes with its integrity less broken than to the exemplar of a handful of Walnuts.

Then eame a nameless implement of private use and manufacture-a mysterious eompound breed, with a grubber for its sire, and an iron hay-rake for its dam, to lift and re-expose the erushed and stifled soil; and then the large and heavy roller to crack the Walnuts; and then-

(Even in the most fertile distriets the Grass erop had been short the previous summer; the quantity of manure was therefore small, and the quality, on a farm that had never borne a Turuip — !)

"Shall we begin the ridging up for the Swedes tomorrow "?" quoth the bailiff. 
"Yes, one half of it; the other half will be manured with gruano."

" With what, Sir!"

I will spare the reader the little seene of utter mystifieation which followed this amnouneement; the subject would be antiquated now; thongh may an amnsing tale might donbtless be told of the first introdnetion of that "magie eompound" upon the rural mind. In spite of smiles, winks, murmurings, shakes of the foreboding head, and other demonstrations, joenlar and serions, the guano was at last duly sown, on the flat, a ton to five aeres, and ridged in; the other five receiving a hundred eartloads of 'the good old stuff;' hauled (nearly half a mile) from the farm-yard, forked into the ridges, and eorered in by a second ridging, as nsual.

'A hundred to one upon the farm-yard manure'! of course,-or any other amount of odds : all bidders, and only one moonstruek, misgnided taker. It proved a miserable year for 'Tumips generally. Everywhere 'The Fly' was omnipotent and omnivorant : the odds fell a little when the highly backed 'farm-yard' ridges had to be sown a sceond time, but a crop eame at last,-abont the size of apples.

And what on the guano: 
From twenty to twenty-four tons, by weight, per acrc. Not 'the best' but ' the only' crop to be seen in the neighbourhood.

If people sometimes get less credit than their due in this world, they must not forget to balanee the aecount with that whieh they get without deserving. The Penguin of the vast Pacific was the Wizard that had made this erop, not I : yet had the wise Chief Justice Hale becn living, not all the watcrs of the Paeific would have saved me from roasting alive.

So much for ten acres out of the twenty-two, and the modern fallow: now for ancient practice, and the other twelve.

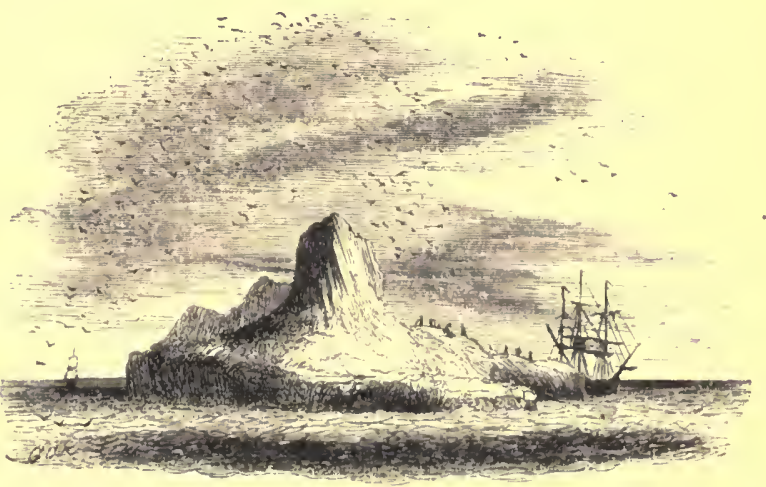

"Ite Wizard of the Pache." 


\section{X.}

\section{THEORY AND PRAC'TICE.}

Тив comparative failure of that portion of my first Turnip erop, which had drawn so heavily and so laboriously upon the meagre resourees of the farm-yard, produeed a changed position of the game, which gave me some surprise. I found myself at length my own screrest eritic. Whether from the contiuning foree of that early prepossession in farour of the 'good old stuff,' which had laid the bets-as heavily as the manure-upon that part of the field, or whether the fact of the mere germination of a turuip-seed where it had never shown its delieate First-leaf before, was trimmpl enough, it is hard to say; but somehow or other it was the fashion to semi-dignify with the title of a 'fair little erop' even those five acres which so wretehedly disappointed my own expectations. As for the erop where the gruano was sown, it went off from 
the first sub silentio: it was stared at and stared at again, as a sort of conjurer's trick which 'you couldn't do again.' Wise men shook their heads and held their tongues at it. Nobody would liave been at all surprised if, on going to the field some fine morning, he had found it altogether vanished, like faëry money, as quickly as it eame: and as the roots swelled and swelled into confirmed substanee and reality through September and October, the silenee about it beeame perfectly portentous. Reluetantly the hoers eonfessed that they had not thinned it half enough; and indeed the loss, from that very eommon eause, was eonsiderable. But where did the erop eome from? how dict it grow? by what means, short of the superiatural, could a mere powder, howerer highly scented, sown by the hand, produee this great fat thriving mass of roots and leaves? Surely it must at any rate be but a fraud upon the land after all; and the next crop would show the different results of real mamure and a mere stimulant. This was the point to which oprsiox at last settled down. 'We'll wait and see,' was the final determination expressed: and over many and many a farm in England and Scotland men did wait, and did see.

Of all the practical illustrations that ever appeared 
eotemporaneously with the announcement of a great doctrine, the introdnction and use of Gnano during the lifetime of Lichig is one of the happiest and most remarkable. If some great physical erent had testified to men's bodily scnses the motion of the Earth round the Sun, and the steady eentricity of that luminary, during the exact life-time of Copernieus or Galileo; or if some conecivable reflection of the earth's surface in the deep azure of hearen, had exhibited to men's wondering eyes the outline of the great Amcrican continent looming along its obverse hemisphere, just as Columbus was collecting subseriptions for his first equipment in quest of it,-they would not cach have furnished a more triumphant vindication of the achicrements of those master-minds, during their own cxistenee upon earth, than that which the more fortmnate Professor of Giessen has been destined to wituess. No sooner had the persecuting infidelity of man (the same in every age) begnu to crucify his great theory of THE Nutmition of Plaxts rRoM the $\Lambda$ TMOSPHERE, than the use of Grano and of inorganic manures began to give it proof. 'Burn a plant, whether it be an Oak-tree or a stalk of Clorer,' (for so the assertion of the great Analyst may be briefly epitomized) 'and the trifling ash it leares will show 
you all it ever got from the soil.' But the bulk, the weight, the great mass of its regetable structurewhere is that gone?

\section{"Into the Air :}

And what seemed corporeal hath melted Like breath into the wind!"

The weight, the bulk, the vegetable mass, of a erop, is simply, its Carbon. Combustion just undoes what GRowTH did: and nothing more. It reeombines the Carbon of the plant with the Oxygen of the air, and their union is Carbonic-acid gas : the very substanee which the leaves of a plant feed upon in the air where it is presented to them in its gaseous form in which alone they can absorb it: they do absorb it; and in their elever little laboratory they piek out the earbon, and return the oxygen; just as our own lungs take up the oxygen and return the nitrogen. Multiply the two surfaces of an oak-leaf by the number of leaves on the tree, and you will be able to form some idca of the enormous surfaee, which the plant annually presents to the atmospliere to earry on this work of absorption.

But the Roots--what is their use then?

Examine them through a Mieroscope, and you will see that, as the Leaves are adapted to intcrcourse with 
Anr, so the Roots are adapted to WATER : not stagnant water: for the sponge rots which is ahways saturated, and their myriad fibres are each furnished at the end witl a sponge, capable of rapid expansion and contraction,- - suited therefore to a medium in which moisture should be ever on the move, downwards by gravitation, or upwards by capillary attraction. This is the true condition of the soil demanded of the mechanical department of husbandry. 'Pulverize your' soil decply,' said Jethro Tull, who thought that plants lived upon fine particles of mould : and he said rightly, but in so far as le said only half, and thought that was ALL, he thought wrongly.

But not more wrongly than every Farmer thinks who fancies that the bulk of his manure is its valuable part. He rather hugs his enemy in this, as he has done in other matters. The bulk and weight of Farmyard manure is simply the carbon which it obtained last year from the Atmosphere; all of which must go) through a long process of decay before it will have set free the Mineral and Ammoniacal parts, which together constitute, when dissolved by water, the suction-food of roots.

Licbig asserts, that if the roots are duly supplied with thesc mincral and ammoniacal substances, the 
rapid development of the leaves will soon obtain sufficient earbon from the air. The labours of the Dungeart, as at present earried on, even in the most improved distriets awkward and uneeonomical, exhibit under more backward management, a system of elaborate extravaganee and loss, which the least ehemical aequaintanee with what we are about, would render utterly intolerable. By frequent turnings in the yard, and long exposure in the ficld, every opportunity for the escape of the Ammonia and every toil in the lifting, hauling, forking, and ploughing-in of the Carbon is lavishly expended. And all "free gratis for nothing," if plants imbibe little earbon at that end. What portion the roots do take up, has to be oxygenated in the leaf and deeomposed again before plants will re-assimilate it: a subsidiary faculty which bountiful Nature has given them, with different degrees of. necessity in making use of it.

But it is otherwise in autumn and winter manuring. Decay is only slow combustion: and when you are burying great eart-loads of carbonaccons manure in the soil before winter, you are making a hotbed under-ground, which will raise the temperature of the soil throughont the long reign of Jack Frost, and preserve many a tender seed that would otherwise 
perish : and herein lies the ehief and wise application of all earbonaceous or bulky manure. Rightly, then, so far as their knowledge went, did our forefathers, who knew nothing of Turnip eulture, plongh-in their long manure before winter : a poor practice at best, we say, to put manure in immediate contact with a grain erop, but not more poor than to apply to a green spring-erop under the burning sun of June the treasures of the Farm-yard whose spirit is exhaled before the body is buried, and whose body is not rotted time enough to afford its remnant of inorganic food to the erop it is applied to.

Who ean wonder, then, that the 'artificials' should sometimes beat the long manure, for Spring application? And who ean doubt that we wise moderns have left half our lesson unlearnt, in having changed the time of manuring without changing also the condition of the manure?

An experiment, whose object was to test the comparative merits of the Aneient and the Modern Fallow, seemed to some people almost unmeaning. The superiority of a green erop over no crop at all, providing that the land is dry enough in the winter for eating or carting it off when grown, was one of those public propositions that people had rum away 
with in a hurry, and got their fingers burnt and had to 'drop it' like a hot Potato, before they had had time to stop and look it in the face.

Fortunately I was a beginner in the full sense of the word. Fashionable opinion was no more a 'ehild of mine' than antiquated Prejudiee. I had the same profound respeet for each and both ; that sort of profound respeet whiel makes you take your hat off very low and keep a eertain distanee off. Not that I was in love with my own opinion, for I had none to be in love with. My agrieultural intelleet realized Loeke's theory of the rasa tabula. Bare fallows had reaehed a respeetable old age, if not a green one, in the world's history; I had no personal quarrel of my own against them; the half of the field set apart for the trial was hideously foul, and stiffer land than the part under turnips ; manure was defieient, and spring-time busy ; everything seemed to favour and suggest the eomparison, so I made it. A dull, lumbering pieee of work it is, too, to spend the "long, long summer hours" in lazily turning the "greate clottes," as old Fitzherbert ealls them, in that quaint passage where he eautions his brother farmers not to be in too great a hurry to break them, a picee of advice whieh every farmer has told as a new discovery of his own touel- 
ing bare fallows, from the time, three ecnturies ago, when Sir Anthony Fitzherbert wrote; and for three eenturies before, perhaps.

But it is trying work, no doubt, to see the ficlds around you teeming with rieliest vegetation-nature all alive in every direction with the bursting wealth of present produce and maturity,-and to toil on nevertheless upon the bare and burning fallow, where the very dews of Hearen refuse their evening tear, and the morning ray darts in wide vain seareh after the liquid Brilliant that it finds on every grass-blade, every leaf, and every flower throughout the rest of Creation. One has heard of 'knocking a man into next week;' such a misfortune might chanee to befall one inadvertently, and on suitable provocation: but to be ploughing next year for nine montlis of this one, and three of the last, to see everything around overtaking you as it were by a twelve-month,--leaves growing more juiey and green, and erops getting richer and riper, and you and your fallow, like a sort of eonverse Oasis,-Desert amidst the Green,-still dragging behind, "feeding the air, promise-cramm'd," a heart-sick waiter upon the deferred hope of next year,-It is trying work, no doubt !

But Life is full of it: and especially of such as this. 
What is Education but a twenty-ycars' fallow, heartwearying and sclf-denying of the pleasures that seem to bloom invitingly around us, luring the warm spirits and fresh feclings of youth, to the easy indulgenec of more active enjoyment and contact with the world. What is manhood but a continued sphere of the same self-denial, another chapter in the biography of Toilfor a future crop-amidst the wistful temptation of surrounding fruition. What is Life itself but a fallow - and bare enough to many a weary and assiduous toiler-a fallow for the future garnering of the joyful crop that was sown in tcars.

And many such a truthful and intended analogy does the Farmer read, albeit no metaphysical scholar, in the book of nature's symbols. They reach the cye of the mind through that of outward rision, without the need of types and words. "It is not Speech nor Language, yet their voices are heard." And shame upon the parent and the country that allows her sons to be banished, at the tender age of childhood, from the sclrool of carly instruction to the labours of the field, before the mind has received that gentle care and training which enlivens, explains, and even dignifies the lowest toil, if toil can ever be really low, as only Ignorance imagines. The old 
Chronieler, amidst his own early blunders and extravagance, has yet had no oceasion to correct the first impression with which he looked upon a ehild turned into a scarecrow for the new-sown ficld, a boy 'driving plough' the livelong day, and a man (a mixd!) threshing in a barn! witlout one hour for the instruetion and derelopment of that higher part which separates his mind from the Brutes, his body from Machinery!

Talk of 'Agrieultural Improrements' - of the diffieulty of getting the labourers to take to a new implement, or adopt an improved method! What enables you to see its adrantage and adopt it? Your Mind. What cultivates your farm better than your neighbour's? Your mind. If that alone be left uneultirated aromnd you,-at every point, at every turn, in every field, in every furrow, in every hedge, in erery ditch, in your House, in your Dairy, in your Stable, in your Barn, ererywhere and at every time, by Day and Night, Winter, Spring, Summer and Autummthe neglect that has been allowed to sow itself, the moral weel-erop, will meet your eye to baffle and torment you with the feeling so truthfully expressed, when you say that you 'have not a single mind you ean depond mpon!' 


\section{No wonder: you have never tried to make one.}

Else, you would not have your Lime overslaked; as I had, during an unavoidable temporary absenec, while my twelve aeres of bare fallow were in progress. Lime was all I meant to give them; exeept a thorough cultivation. Every ridge was levelled: not an elevation or a hollow remained: the subsoil that had been exposed through the winter was thoroughly intermixed : the plough and the subsoil-plough had equally done their work; and fifteen quarters of lime to the acre was all I added, before the seed was sown.

My great object was to see the speeifie operation of lime upon a worn-out soil. If written words may be relied on, it is the most puzzling substance the farmer has to do witl. The eliemist tells us, and with truth, no doubt, that it has two distinet effects; one upon regetable matter whieh it helps to deconnpose; the other upon mineral matter which it 'eorrects.' Such is the word, and we must use it for want of a better. In the first operation it is virtnally a 'manure,' beeause it turus into food for the erop organie matter which would else have remained inert: in the second it is an inorganie alterative, supplying ealeareous matter, and forming a base for the free acids exposed in the freshly mored subsoil. 
I liad taken some pains to aseertain the previous character of the field. Fifteen or sixteen bushels to the acre, (undrained, and in high ridge and furrow,) was the ntmost erop the memory of man could furnish an account of.

The crop of Wheat eame up well, looked even and healthy, but not thick, throughout the succeding smmmer, and ripened late. The produce, when threshed out, was six-and-thirty bushels, including rather more than half a bushel of 'Tail,' to the acre.

How completely the Lime had done its work, in both capacities, may be judged of from the fact that on a couple of acres which I retained expressly for the after experinent, and sowed with Beans and then with Oats, mmanured, the two suceceding years, the return exhibited an utter exhanstion of the productive powers of the soil, to an extent that I could hardly have beliered, withont experimental proof.

'Though it eamnot be desirable to see the practice of' hare fallows cxtended; for it exists too much already upon many soils where it might be with erery advantage snbstituted by green-erops; it must yet be borne in mind that it is not in the nechamical strncture alone that heary soils differ from light soils; their chemical difference, which is quite as great, lies in 
that essential particular that the elay soil is naturally richer in the mincral constituents required by your crops. Potash, Soda, and Phosphorus, which you must supply to a light soil before you sow it, you have only to develope in a clay soil by decp and frequent stirring, and submitting to the oxidation of the atmosphere. The grcen-crop, with its carbonobtaining leaves, will no doubt supply organic wealth to either; but inorganic food can come from the soil alone; and if the soil be able to supply it from its own resourees, one-half the value of the green-crop, as a fertilizer, is renouneed. Its remaining value, as a collector of organic matter from the atmospliere, is the point upon which the question will be poised, of its adoption on a soil which after effectual drainage, sub-pulverization, and liming, still retains the character of a 'elay.' Eren upon such land, (which is not so plentiful as some imagine,) experience has yet to prove how far, by deep ploughing and sub-soiling immediately after harrest, and making the most of suitable weather between that time and the following summer, the useful Swede or 'Turnip may take its place in a six-course system as profitably as in the four-course system upon lighter soils. The bare fallow is too ancient, too prospectively laborious, and 
patient, not to have deep reason at the bottom of it. Chemistry has only explained the truth which Practice had established. The question may be, not whether the fallow shall be abandoned, but whether its objects can be aehieved at a less sacrifiee of Time.

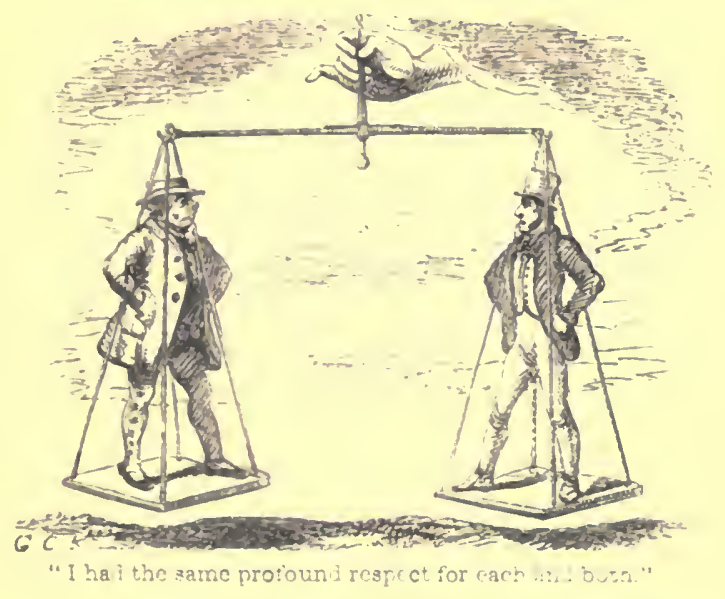




\section{No. XI.}

\section{DISSOLVING VIEWS.}

Is these busy days of Land-navigation, when a man ean hardly travel twenty miles along the old fashioned high road leading from anywhere to anywhere else, without rumbling under the skew areh, or half dislocating his mortal framework over the temporary bridge, of a 'Railway in progress,' as Mr. Bradshaw, with monthly moekery and pertinaeity of promise, ealls it, most people may have had opportunities of notieing eertain funnel-shaped pyramids of earth left standing in the 'euttings,' whieh, if not exactly like their prototypes,-

"Flinging their shadows from on high, For time to count his ages by,"

yet answer very satisfactorily the more modern objeet of showing what deep wrinkles the faec of mother earth may reeeive in short ehronologies, and what 
geologieal liberties people take with her in her old age to what they used to do; inverting her established strata, shorelling Lias, Chalk, and Red-sandstone over each other in most admired disorder, leaving only these frail memorials standing as if by way of a small sample of 'England before the Conquest' of spade and wheelbarrow.

When looking over the ehanged aspeet of a twenty acre field, with its drained, deepened, levelled, manured, turnipped, barleyed, soil, smoothly smiling under the sunshine in its first year's Clover, how often I have wished that some such relic of its original state could have survived, to present to the imaginative eye that now sees it for the first time, the long story-

\section{" Eheu! quantus equis, quantus erat sudor Viris!"}

and furnish a reply of befitting smartness to the coldblooded eruelty of look and phrase that extinguishes all your pride-full thoughts by some such damning praise as this:-“Well! a very nice field; a very beautiful field, indeed! very niee, but a- I don't sec anything particular, not very particular at least, in it. I'm no farmer, you know; you'll exeuse me," sc.-" Excuse you! W7y, what upon earth did you come out to see?" I long to ask of each gaping 
sight-sceker, who scems to have expected a series of dissolving views, or some dioramic transparency exhibiting Drains running, Sub-soil crumbling, Ammonia fixing, Turnips growing, Sheep fattening, Wheat reaping, and all the phenomena that 'trammel up the consequence' of agricultural emprise, much after the fashion of the nursery tale that finds such rapid dénouement when "the eat began to cat the mouse."

Beautiful in every best sense of the word as an improved and well-cultivated farm may be, how bashfully does it reveal to any but the descrving eye, the eyc that has rightfully and laboriously carned its perceptive skill, the dereloped eapability and power obtained by the soil from the judicious appliances of art. The Painter may draw a Landscape, the Florist may furnish a Hothouse, the Landscapegardener may produce an 'effect' with compendious skill; but there are two things in nature bearing truthful analogy with each other, from the world of matter to that of mind, which defy the hand of imitation; both are comprehended by the one same word, cultivation. It carries no label on its back, no title-page or illustration to the idle speculation of the eye; it is no talker; it asks " an understanding, but no tongue:" full as Nature is of ormament, at every 
stage she disdains to make an exhibition of her intrinsic progress at any. The railroad workman leaves a pyramid to mark the ancient ontline of the surface; and it is wise in him, for he has a motive in the retrospeetive measurement. But with nature it is not so: ONWARD is the eternal word; and the memory how this meadow looked when it was that morass, or this fair ficld when it was that jungle of high hedges, stunted ash-trees, tangled bushes, with doeks and thistles to correspond,-to say nothing of heared-up ridges and crooked furrows,-all is past; and he who looks on it as it is, might as well ask leafy Summer to show him how Winter looks on the same spot, as expeet the improved ficld to show him the history of its improvement. "Oh! Sir, if sou had but seen this field as I remember it!" has becu the half-mortified exelamation or remoustrance of many a worthy toiler upon earth's surfaee, whose handywork has left no landmarks except upon his own brow. "If you had but seen it as it was;" - and there the interjeetional sentenee ends unfinished: would it be far from the truth-a truth that will be one day better understood-to coutinue it thus :-

-You would give honour to the toiler and the toil that are cmployed in earrying out the beneficent 
designs of Providence for man, in subduing, fertilizing, and beautifying the spot of earth on which his lot is cast. You would ask why for thousands of years we have crowned the Warrior with Laurels, the Poet with Ivy, the Citizen with mural crowns, and the Husbandman with-nothing. You would ask why his achievements are without record and his name without honour; and his only reward that which is to be found in the words of the stern satirist:"Laudatur, et alget."

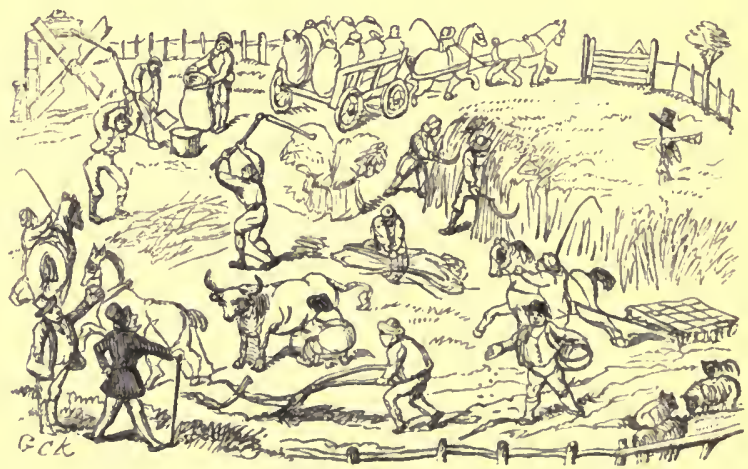

"Eheu! quantus equs, quantus erat sudor Viris!" 


\section{XII.}

\section{A WORD AT PARTING.}

Murky days of November ye have eome-and gone again,-over one at least who has found out and tasted of your Poetry : and in turning over the leaves of a erowded diary of years and days gone by, his hand can searee touch without the gentle pressure of old fellowship the page after page that recounts the aetive busy-ness whieh lighted up even your dark atmosphere and drizzling skies; till the spent and scanty day again and again drove him, reluetant, to the 'bell, book, and eandle,' from whieh the mind would wander back a-field, orer every yard of nicely levelled drain; and hear, in fancy, the drip drip drip going on through the silent night, while weary labourers sleep, and Nature, the unwearied labourer, sTILL works alone.

What a thought-to the mind that knows its his- 
tory and value-ay! he may be bold enough to say who has known and felt it,- what a blessed thought is a well-drained Field! A portion, a small yet measurable portion of Nature's reality, brought by the hand of man from sterility to fruitfulness-from its first and incomplete existence to its intended and developed state. What a thought to checr and lighten the dull November fog, - - that hundreds and thousands of acres in this moist England of ours which once began their annual saturation with the Autumn rains, and lay in barren quagmire the livelong Winter through, unwakenable from the clammy trance of their yearly death even by the cheerful roice and breath of coming Spring,-are now gently transmitting through their porous texture, the healthful rain that feeds what it once poisoned; and that as every shower ceases, then comes a rich aftcr-gift of atmospheric air following in a thousand sinuosities the threadlike channels down which the rain, like a pionecr, has found and led the way through the soil, to the rery drain, threc or four fcet below the surfacc. What a thought is this, to those who know it, and have earned its plcasure!

Nature abhors a vacuum. True, most true, O philosophic chemist! Where the drop has once disap- 
peared through the soil, it has dragged the air after it, and with the air, its burthen of medicament, food, and temperature, down to the once sluggish and unawakened subsoil that never felt its animating touch before.

"Olı! Sir! It's a fine thing, is this here draining," said an old labourer, lifting up one heary foot on the ledge of his spade, and composing limself with his elbow resting on the handle, to say a few words, before he put his jacket on and parted for the night.

"It's a fine thing is this here draining: what a crop o' Turnips 'll be here next Autumn, I'll be bound to say!"’

Of all things I like to cateh the toiler in his spare but hearty moment of contemplation. The uttcrance of an abstract thought or reflection is never so precious as when it struggles for a moment from one whose frame is almost bent double with tlic hard practicality of daily labour. I prize it beyond words.

"It is a glorious thing," replied I; " the more I see of its effects, the more I like it, and the more I wonder how the land was ever worked before without it."

"Ah! well, Sir, 'twas a different sort of thing you sec,-'t was like a different traade. Lor' blesh you, I remembel the time when after Wheat-sowing was 
done (and sometimes there was many ficlds so as it couldn't be got in at all, when it eame a wet season) the farmer's work was over like, for the year. There was nothing to be done but sit at home and go to sleep, till the Frost came, and the dung-eart could be got a-ficld. It was bad work, sir, for the labourerbad work-when he was turned off for the winter, and had to look out for a bit o' hedging or ditehing somewhere else, miles off perhaps, to get a bit o' bread by."

"Well, we've changed that however: I think I may truly say that every year, to me, Winter has been a busy time."

"And it will be too! There'll never be standing still for winter work again on this here farm, as long as ever it lies out o' doors, let who will farm it! for all so many hedges are grubbed up. How the Swedes have growwd, to be sure, on that piece as we drained last year! I never saw Ship look better: and I remember when there wasn't a ship on the farm, or a Turnip on the ground to feed 'em with."'

"D' ye think that picee will stand the treading of the sheep?"

"Bear it! Lor' blesh you, it 'll eome up as mellow as a garden, I'll war'n' it, in the spring: it treads a 
little leathery in some places in the middle o' the lands, but that'll all eome right after another erop: it don't all come at once after draining; every year tells on it."

"You think that really is the ease?"

"Think! I knowws it, Sir. I likes it every year the better arter the draining: but I do think (you'll exeuse me,) that you goes a little too dip with the tiles: it is no use going so dip into the clay."

"What, three feet! Why they laugh at me for draining so shallow! If you were to see what they say in those Papers I bring into the field sometimes, (in a morning, you would n't eall this deep." -

"Oh! never you listen to what them there papers says, they know nothing in the 'varsal world about it. They beent practieal farmers as writes that stuff: none $\mathrm{o}^{\prime}$ them as writes knows anything about farming."

"D' ye think not? Well, but now suppose I were to write about the fields we have drained, and send it to some of those Editor men to print and put in the paper, wonld n't it do for somebody else to read: would n't it be as true after it was in print as it was before, when we were doing it?"

"Ol that's a different thing, that is; 'eause of eourse they'd believe what you say___" 
"Well, now-suppose I were to put it as a sort of history of this Farm, as it was, and as it is,-a sort of chronicle-call it the 'Chronicle of a Clay Farm '-?'

"Oh that's eapital! Lord how I should like to see it: that 'ould be summat like, that would! none o' them there long words about Chemists and Druggists and Doctors' stuff, as if farmers was a parcel o' old women, like my poor old Missus__ oh! thank you kindly Sir for what you sent her, it did her a sight o' good, she was able to eat her vittles better arterwards than she's done for many a day-"

"But you won't believe I ean doctor the field and give that an appetite, ch Dobson?"

"Well I don't know-I ben't no scollard, Sirone thing however, you've tapped the dropsy on it, for one thing, that's sartin!"”

"And you'll belicre the other when you've seen it. Well, good night Dobson!"

And with a hearty 'good night' in return, trudges poor old Dobson home from his hard and wet day's work, with none the heavier heart or less elastic tread for a few eheery words to enliven the dull blank of the body's labour, and illuminate for a moment that hateful chasm that lics too broad and forbidding 
between employer and employed, in eivilized England.

When will this stain depart from our land? When will that moody silence and reserve that diseonnects rank from rank, and class from class, and man from his brother man, eease to shut us up from each other's view, like sealed paequets of humanity, destined and direeted 'private and confidential' each to its omn special clique and circle, locking up the eheap yet gladdening benevolenee of words from all 'below' it.

If man, vain aspiring man, did but truly measure the resilient influenees for good or ill, by which his own existenee is surrounded; if he did but know the rich freight of happiness and of positive blessing to his poorer and humbler brethren, which he bears within him in the mere gift of language. If instead of rescrving all his soft words for the rich, and the caressing of the tongue for those who least require or value it, he would stoop to remark its instant effeet, and permanent influence for good, on those who seldomest receive it, how ehanged would be the working out of that strange problem of society which is erer leaving the largest numbers most uneared for, their power and influenee only felt when it is dangerous.

Of all the sweeteners of human toil, of all the 
motive powers that give alaerity to the hand or foot, readiness to the will, intelligenee to mind and purpose, the quiekest and the most enduring in result is the kind 'word spoken in season.' "How good is it!" exclaims the Wisest of the sons of men. The most boorish obduracy melts at last under its repeated influence, though hard and rough at first as the unsmelted ore. Horse-power is eonvenient of applianee, Wind and Water power are eheap, the power of Steam is great, the sordid power of Money greater still; but of all the powers that be, to rid the tiny weed, or fell the stubborn oak, the greatest is that whieh ean gear on mind to matter-the wors and LoOK of KIN DNESS.

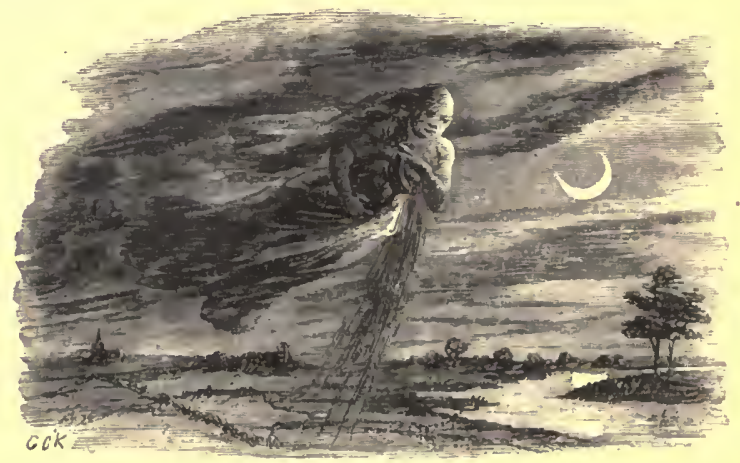

- On, through the silent night,-

Whlle weary labourers sleep,-still works, alone.' 


\section{[SECOND SERIES.]}

\section{XIII. \\ 'FARM TO LET.'}

The town of Bogmoor is not famous in History : nor indecd geographically. It may not perhaps have challenged a very responsible amount of public notice hitherto, either for its own merits in gcucral, or for that reflected virtue in particular, which has cast a queer distinetion upon Marlborough, Wellington, and a few other 'small towns with great names' that might be mentioned; and that sometimes are mentioned, in fact, with a yawn of carcless wouder, why 'Duke of Blenheim' and 'Duke of Watcrloo' would n't have donc as well,-perliaps better, than tying on the name of an obseure town to the laurels of the hero, like a penny ribbon on a prize Longhorn.

But however, that is not the present subject,undeed as far from it as possible,-for the real point 
was to show that whatever the world at large might say or think, or not say or think at all, about Bogmoor, it had a comfortable kind of self-opinion of its own that amply outbalanced all public indifference. Indeed the place was utterly chloroformed against any sueh sensibilities, and was quite of the opposite way of thinking; reminding one of thosc people often met with, who for some eabinet reason that never can be got at, seem to view every object in life through that lens by which the dilated eye of the drunkard is said to make everything he meets look small. As you walked or rode up its one long flat dull straggling street, it was strange to remark the eontrast between the street itself and the faces that met you in it. How upon carth so mueh self-satisfaction had ever been got together in so unsatisfactory a spot, was the indcfinite wonder that was stirred afresh in the mind by every object that met one's eye. The very eurs popping extemporancously out of wet narrow alleys, imaged, while partaking of, the character of the place, cocking up head and tail as you passed, and exerting both together in one short 'Who are you?' bark of ineonceivable impulence.

Whether in aggravation, or explanation, of the whole secue one ean hardly undertake to say,-but 
there was one large bow-window visible a long way up the street and down the street-and indeed up and down another strect too, (the only attempt at a cross strect there was,) for it was a corner window, commanding therefore at a glanee all the news of the town.

Ay! and a deal more too! Its wide look-out was, like the little dogs just observed upon, emblematic as well as actual. It was the News-room, Reading-room, Petty-Sessions-room, Literary - and - Scientific-room, Farmers'-Club-room, and a great many other rooms besides, that there is not time to tell. Enough to say that the smallest pin ever manufactured eould hardly have alighted point downwards on the floor of that room-metaphorically to speak-but crerybody heard it ten miles round, and could tell you the shape size colour and manufacturer's name within the twentyfour-hours: and that was short time in those days.

I shall not deseribe that room or its bow-window any further. I conecive that the heaps of news-papers, with the noses and spectacles poring orer them, and the polished mahogany tables, to sit and read them at in the windows, so as to command the news inside and outside, are sufficiently visible to all average minds'-cyes without more specifieation. 
Now it happened that at the top of a column in the advertisement-page of the Wetlandshire Mereury which was lying fresh and damp from the Press, and easting a hazy pattern of itself upon the polish of one of those same mahoganies, there appeared one Saturday morning in the autumn of the year Eightecnhundred-and-thirty something, a short dab of an advertisement in the following spasmodic phraseology :-

"Wethandshire.-Farm to let; on Lease. 250 acres. One third Meadow and Pasture. Has been drained and otherwise improved in the hands of the proprictor. Capital required, $10 l$. to the acre. Application, to Messrs. Peun and Debbitt, Bogmoor, Wetlandshire."

"I say, Mr. Bowles, have you seen this Farm that's advertised here?"

- said a gentleman sitting in the window, to another gentleman, in deep perusal at the fireplace, of which he had taken sole scisin, holding it by the hobs-with his feet.

"Yes:-No: What is it:" said the roiec from the fireplace, uninquiringly', and smothered in a 'leading article.' 
"Why here's a Farm of two hundred and fifty. acres to let 'drained and otherwise improved by the proprietor.' I wonder whose it is : that's just the sort of farm young What's 'is name was wanting-that 'ou'd just suit him, would n't it?"

"Well, what is his name," returned the other voice, mininquiringly again, and never looking up.

"Why young-oh! what is his name-I shall forget my own soon" - (a grmnt from the fireplace) "-young Leejohn, you know him. You don't mean to say you don't know him?"

"I didn't say I didn't," answered Mr. Bowles with provoking gravity of iteration, bent upon giving the smallest modicum of intelleet to anything else till he had finished his 'leader:' which having just aecomplished he starts up, lets go the hobs, and parting his coat-tails, turns round, and again takes possession of the fire; indeseribably ; and waking up to the subjeet, asks,

"But low ean he take it: you said 10l. to the aere didn't you? He hasu't the money. ('Legion' indeed !)"

"'ord blesh ye!"

Added to a toss np of the ehin out of the eravat, to grive emphasis to the middle word, this invoeation 
eonveyed all the answer that was heard, to the difficulty started by Mr. Bowles. What the exact meaning was that lay wrapped up in the blessing - whether it was peremptorily farourable to young Lecjohn's pecuniary eapabilities, or conclusive of some indifferenee attaching in toto to the inquiry, has remained dark to the present day. The subject fell, strangled by some larger topie of news-room discussion: and the Chronicle is without a scholiast.

Two or three days after the appearanee of this epigrammatic announeement in the 'Mereury,' a thick and weighty-looking pacquet, direeted in what may for contradistinction's sake, be called 'Square-text,' might be seen lying upon the margin of a breakfasttable on which lay also an admired disorder of newspapers, books, farm aceounts, and coffec-eups. The room itself in which the table stood is just worth a moment's notice before anybody eomes in. Smalt, oak-pannelled, and too square for proportion, it was crammed, in every corner and upon every table, with miseellaneous piles of articles which seemed to have grown together by degrees in spite of original ineongruity, and beeome reconeiled at last by lying under the same dust. 'Indoor' and 'out-o'-door' seemed to eontend for the mastery all over the room : 
if you looked into the eorners you might have faneied yourself in a garden-tool-house, if you looked on the mantel-picee you thought of a ehemist's shop: four dried lumps of soil, as hard as stones, lay at one end of it on separate pieces of ex-white paper, and through their coating of dust feebly indieated the three primary eolours, blue red and yellow, with a sort of grey for the fourth. Over several tiers of news-papers between the windows, at the further end of the room lay at full length two 'new and improved' Drainagelevels,-out of Spirit though,-for each was earefully tied up with a direetion eard to the maker: 'rejected addresses' evidently. Odd combinations, unmeaning and half meaning, disported themselves over the confusion of the little den: the end of a large pruning-knife peered out between the sheets of a new half-eut volume marked 'Dendrology', suggesting something about Theory and Practice, and elearly exhibiting, by the jagged leaves, the moral as well as physical truth that sharp knives are bad paper cutters. An old quarto volume of Raleigh's History of the World, in black letter, lay open on a little table near the fireplace, with a bundle of Cigars and some papers of Potato-seed on one page;-and a small sharp Axe on the other. A whetstone lay 
near, and a drop of blood, along the edge, had left mark of some awkwardness or haste and had smeared the page below with an ugly red line under the word Gratitude. Except a tolerably well filled book-ease too much stuffed with stitehed reports and periodicals, there was nothing else noticcable in the general medley, excepting an ingenious atrocity in the shape of an easy chair with a traversing desk, and a shaded reading lamp, serewed into one of the arms. A wood fire had burnt out in the hearth, leaving the ends of the brands reclined despondingly against the 'dogs,'old-fashioned biped articles, which reared eacl a neck and head of silver, by way of focal ornament and finish, and which people who eame on business always fixed their eyes upon, and at some conrenient pause registered their approval of, in a tone that took some eredit for originality of taste.

The windows looked east-ward, and the sun was shining in : the weighty-looking paequet had not been long on the table before the door opened, and a shooting-jacket, waistcoat, and trowsers, all of the same pattern, entered the room: a eup of eoffee was hastily poured out, and the seal of the paequet broken. A quantity of letters fell out; one of which ran as follows. 
"Dear Sir,-We cuelose to you applications for Farm, marked 1 to 14 , of which be pleased to return those you wish answered. Six parties ealled yesterday, wishing to inspect personally and have refusal of same. We will forward you further particulars tomorrow.

$$
\begin{aligned}
& \text { "We are, Sir, yours very truly, } \\
& \text { "Pexi and Deввітт." }
\end{aligned}
$$

'Marked one to fourteen-plus six' muttered the owner of the shooting-jacket, slowly putting down the letter amongst the others, seating himself in the arm-chair and swallowing the lion's half of the first cup of coffec. "Two days' notice-" no! not so much ; not two"-and twenty applications.-Hmm!'

Having delivered limself of this refleetion with that deliberate and abstracted utteranee betokening more thought than syllables, he gradually fell into a posture - the head upon the hand and the elbow on the chair-arm-which indieates that state of mindderiving its name from the eloven footed-race who patiently swallow things twiee over, dining at one hour and ehewing at another,-yelept Ruminating.

'And so, my poor old Farm, I must now bid you farewell. I who have taken your part throngl good and ill report,-know the eourse of every drain and could find blindfold every weeping outflow that has 
wrought so fair a change in your onee untoward look, and ill name : earth's tears of penitenee and Promise ! I who have taught you by anxious toil through many a long dull day that serene and smiling look you wear this lovely morning, which even in your plain faee betokens something good at heart. Well! may he who wins deserve,-as many a sad heart has said, after all its watehful eare, in eases not altogether dissimilar.-Now let us see something of the suitors !'

This last remark seemed to have referenee to the heap of letters 'marked 1 to 14,' but before the aetion eould be suited to the word, it was arrested by something whieh aforetime has arrested a good many words and aetions : a gentle кмоск.

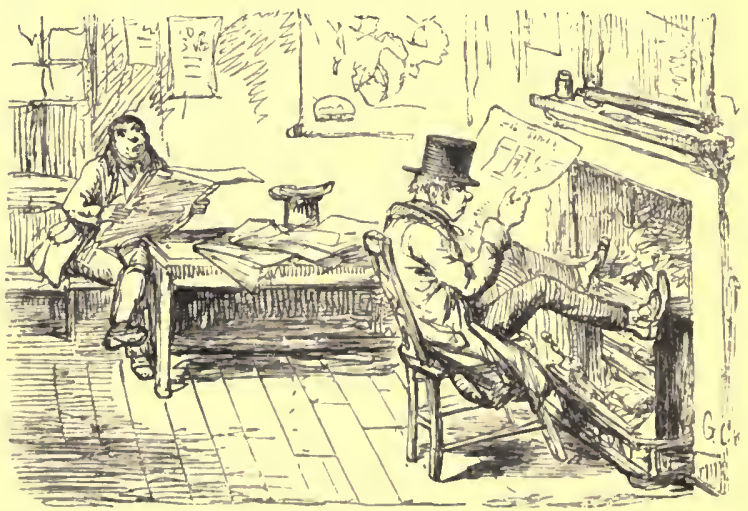

"I say, Mr. Bowles, have you seen this farm that's advertised here?" 


\section{XIV.}

\section{AN 'APPLICATION.'}

If there is one class of mind in the world with a native antipathy to improvement, there is another, and much more really misehierous, which secms erer destined to earieature it. As every animal, however noxious, and seemingly useless, has its appointed prey, so do the natural enemies of all scientific advancement in their own art, trade, or calling, whatever that may be, find a never failing source of triumph and enjoyment in eracking the bones of blundering Enthusiasts who dog the path of progressing 'Trutl, like distorting shadows, throwing her calm elear profile against each passing object, in every variety of burlesqued and ridieulous outline. It has puzzled philosophers of moderate patience and observation, to reflect upon this fact: forgetting, or never having noticed, the gentle-handed toleranee 
whieh marks the parent-diseipline of Nature, over her inter-squabbling and mutually-intolerant ehildren, they wonder she interferes so seldom, and with sueh mild half-measures, to reseue her beleaguered sons if not from the foes in front, at least from the fools behind that go bleating about, exaggerating every fact, like street-news-mongers; dressed in the livery of seienee like a monkey in regimentals, and understanding and appreeiating the language they talk at seeond-hand, as mueh as the organ-grinder does the opera-tune that his wineh works threadbare.

A good solid impenetrable advoeate of old-fashioned ignoranee, falling foul of one of these light gentry, snaps him up at a mouthful; and no harm done neither: but the misehief lies in the eorollary-'So mueh for your Science!'

Agriculture has had enough of this, and something to spare. Counterfeits of every sort and shape have erowded at the heels of every improvement, every invention, every good suggestion, every new manure; till Art and Seienee are well-nigh ashamed of the sound of their own names, and are fain to wear smoek-froeks for ineognito. The plague that has reached its height in the prescnt decade, was beginning 
its infective process in the last, of our ninetecnth century. It knocked that grentle knock at the door that ended a former chapter of our chronicle; and it was ushered in, (as what plagne is not?) in the most pleasing and attractive form imaginable.

A very young-looking little personage, very smartly dressed, having sat himself down, and got pretty well at ease in the course of a preliminary amouncement that he had ridden over thus early in eonsequenee of a risit to Messrs. Penn and Debbitt on the previous day; without giving much occasion of reply, proceeded to deliver himself of a little harangue of which the workd at large having already been delayed the benefit, some ten or fiftecn years, must now content itself with an abstract.

It appeared-from this discourse-that Agriculture was a most interessting hart-but quite in its hinfancy -quite entirely so. The farmers were a very hignorant class, and knew nothing whaterer abont itnothing what-herer. The land did not prodnce enongh by arf-not a quarter what it hought to deu. Summer fallering was a shocking waste of time and expense: a pair of 'orses were enough to plough the stiffest land-to any depth. Farm-yard dung was good for nothing. Go-anner was the thing; and the four- 
course system, which no landlord ought to allow his tenants to adopt hany other. Six feet deep and forty yards wide was decidedly the proper depth and distanee for drains, and if the elay was well stamped down upon the tile this would drain the wettest land hamply and effectchally. But no 'agriculturist' could be expected to lay out his eapital in these improvements without a Lease-nineteen ycars at least, as they ave in Seotland. With a demand of whichafter many other useful hints about Game, \&e., the lecturer concluded his remarks; offering to excmplify them in his own little person upon this identical 'Clay Farm.'

The stupid old chronicler meanwhile-(the wearer of the shooting jacket before-mentioned) during this eloquent outpouring, scemed somchow to have got into the elouds. During the first half of it, he had never taken eyes or ears off the speaker; when at length he did, it was only to put his hand and handkerelief over the former, so that they were quite buried, though onee or twice a kecn observer, not himself oratorically engaged, miglit have just perceived a very slight spasm or convulsion of the figure, and a sudden redness of the temples over the edge of the kerchief; but the momentary cougl, or sneeze, or 
whatever it was that ailed or choked him, passed away; - and when the address was over that had been charming so long and wisely, he looked slowly up, like a person whose thoughts had been wandering far away, and must be recalled like a lot of stray heifers, before he could put the question-

"Have you farmed extensively, Mr. ,

"No, Sir; not exactly-at least-not myself as yet; but I've seen a good deal of agrieulture; that is, I've been orer some of the most celebrated agrienltural establishments, that of Mr. Speedwell in Netherlandshire-the Rer. Mr. Foreechalk's Farm on the Highdowns : I've been orer Lord Burytile's Drainagerorks in North Dampshire, with his Lordship's steward; and I am familiar with Mr. Mac Scuffler's great eonecm in Inthemess shire, N.B.-I know Mr. Mae Scuffler very well. By the way I presume, Sir, you allow a tenant to take hout?"

"I beg your parlon?"

“Yon woukl allow me, I say, to take out-a' I'm not much of a sportsman myself, but if a friend should eome-"

"A ecrtificate - oh! I understand:- You've secn the Scoteh farming then? did you study long with Mr. Mae Scuftler?" 
"Oh! no: it wasn't to study: I often go and stay with him: alı! that is farming! He hasn't an acre of grassland: not a bit exeept the grass-plot before his door, and he says he shouldn't keep that exeept to wipe his shoes on."

"Ah! well: We are rather proud of our dairy pastures though, here. Are you married Mr._-? Excuse my-"

"Not yet Sir, but I'm going to be. It's on that account I'm going to take a farm. I've a thousand pounds of my own; and She-that is-lier aunt, who died lately, left her a thousand pounds; rather more I believe-so we shall have plenty to begin upon. Mr. Mae Seuffler has promised to send me a Seoteh plough and four eapital horses, Clerelands I think he ealls them ; such steppers! you'd be astonished to sec the rate they go orer the ground."

"Are her family connected with-with 'Agriculture,'-is her father a-"

"A Farmer? oh! no. He was in trade: but he is dead: she was living with her aunt till lately."

A few moments' pause ensued : the fice youthful expression of self-confidenee on the faee of the speaker eontrasting euriously with the somewhat puzzled and half-painful thoughtfulness expressed by 
the other party to this brisk dialogue. This expression howerer suddenly changed-and getting up and going to the book ease, he pulled out, as if in referenee to the discussion just pending-a thick quarto volume; and having blown a little eloud of dust from it into the fireplace and rapping it together once or twice, apparently to complete the purgation, he walked up and quictly laid it down, open, before his visitor.

"Would you oblige me by reading me a page of this?"

The other stared-" Read this! why gracious me, Sir! I can't! Why, it's Greek or Latin or somethin'!"

"Three lines will do."

"I can't, Sir, really! I couldn't read a word of it if you'd give me the world!"

"One single line."

"I can't indeed! I never learnt a word o' this stuff."

"An agricultural author too! His name is Theophrastus. It's all about Wheat, Beans-Egyptian beans-the same you buy at Mark-lane kiln-dried, and all sorts of other plants and regretables. Surely you can read it?" 
"Not if all I have in the world depended on it! I never learnt the alphabet!"

"Thank you, my young friend-that's an honest answer. Now observe: you are going to pledge 'all you have in the world,' and all that Somebody else has too-that you ean farm; and you've never learnt the alphabet of that! The task you see before you in that book, and think so diffieult, is but the aequirement of a few years; the other is the labour - of a life-of many lives-and not learnt yet. I'm not joking, beliere me. I speak scriously; I've burnt daylight and eandlelight-a fair share, over both. Why do you think-why does ererybody think-that he can farm without having learnt how ; that agrieulture (if you like that word best) is an exeeption to every other human labour or pursuit, a eontradiction to all Natural Law, and will bring a livelihood witlout study, eost or apprenticeship: that to be able to gabble over the pet jargon about the ignorance of our forefathers-"

The old Chronieler was warming up-and beginning to lureh about in his ehair like a grain-laden Dutehman elearing out of harbour;-but a look of something in the other's faee just happened to eateh his eyc-a look that somchow can break down-and go 
right through a barred and bolted door better than artillery and powder-bags-a look that trips up anger and makes it fall flat on its face-that melts arguments into a jelly - a sort of look between simplieity and penitence- $\mathbf{a}$ slight quirer about the mouth like that of a child convicted in a first fault-

The steam was turned off in an instant-the safety valve opened of its own accord: that precious valve that the Great Author has plaeed in the inner heart of man, no matter how many rough coats are wrapped over it-

"Come, come! We'll make a bargain after all. An carly visit deserves to do business. You're still young-very young. Take a word of adviee from an old hearl. Go to your friend Mr. Mac Seuffler-ask him to take you for two or three years:-it's soon gone. Work away for dear life at his farm, and make him tell you all he knows. Faney that it is your money instead of his that buys every ton of manure he expends. Put off your wedding a little bit: she'll be constant if you are: and come to me three years henec; I was as young as you once; and when you're as old as I am you won't repent my advice. I'll look out something by that time that will suit you better than this." 
There was a shaking of hands. A promise on both sides: The door elosed: and the momentary flush of warmth fell away from a pair of old eheeks, like a red oak-leaf from the bare bough of Norember, as the letters 'marked 1 to 14 ' were slowly taken up one by one, and glanced at with the leaden eye of habitude.

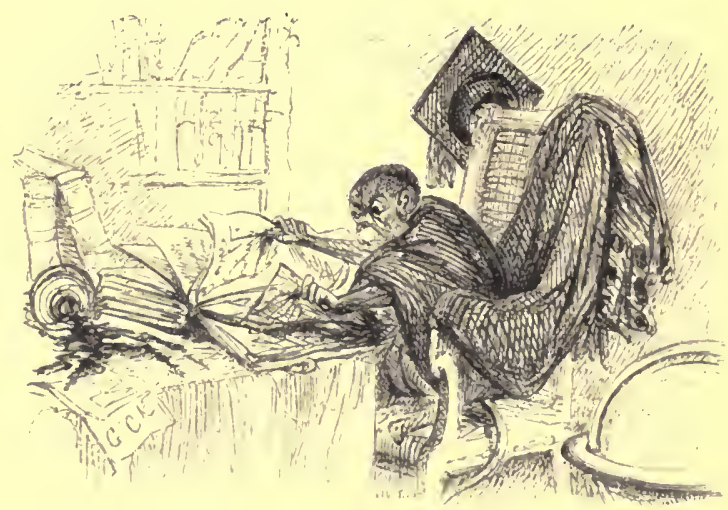




\section{IV. \\ 'LINDLORD AND TENANT.'}

To people of that happily constituted mind in which the hope and faith in the moral progress of their own race, and the sanguine watehing of its slow-erecping evidenees, furnish a continual, albeit a slender, banquet,-whose patient and far-reaching charity may be truly said to "feed upon air, promise-crammed ;" it must furnish an oceasional, and not infrequent pang of almost despondeney to witness how slightly, how remotely the best remarks of the best philosophers, the most practical adviee of the most practical moralists, does actnally reach, touch, affect, enter into, or flavour the reeiproeal thoughts and actions of men in the working-day rontine of 'business' life. Business is the word, business is the exeuse, business is the conventional and acepted basis for a code of human action, as mulike and opposed to what is de- 
elared, and sineerely believed, to be eondueive to true happiness in every other department of life, as Monday's eonversation is sometimes at varianee with the good feelings or good resolutions experieneed at the elose of Sunday's sermon.

It is as long ago as the days of Charles II. that in one of these same 'Sunday sermons' a remark was made whieh has not only travelled down safely to our own time, but enjoyed the more remarkable truthstamp of instant aetivity in its own, in being earried away by two listeners, who the following dlay met eaeh other half-way to shake hands, and settle by a little mutual eoneession, some matter that had long kept them wide apart. The remark was that "Selfishnesse seeking but its own sunshine is blynded, lookynge on the light; but wisdome, like a true areher, turneth his own baek to the sunne, and letting the light fall upon the mark, taketh the steadier and surer aym: and thus should he who seeketh his own happiness eonsider well the posture of his neighbour, and plaeing himself therein, look baek as it were upon himselfe; and most surely, after due habit (for the tryal is at first of difficult empryse), he shall find the whole matter between them sueh as one may presently know wherein the due eorreetion lyeth." 
To those eomplieate relations of life in which there is at onee antagonism of interest yet mutuality of $o b$ ject; to that relation (for present instanee) implied by the words 'Landlord and Tenant,' how elose, how admirably apposite scems the quaint rule laid down by the good old ehurehman! 'Place yourself in your neighbour's position,' he seems to say (though indeed his language needs no paraphrase), 'and look baek upon yourself from that point: the thing is diffieult, and there is little danger of your getting too perfeet in the art of looking on your own interest with your neighlbour's eyes. Let the Antagonism between your interest and his be for the time imaginary, the Mutuality real. So will you see your own best interest and happiness in truer light and leisure, by taking your neighbour's judgment, even for his own ends, into council with your own.'

The too frequent praetice is to do the exaet reverse: to realize the antagonism, and make the mutuality a fietion and a humbug. What the effeet is-first upon the soil, seeondly upon the labourer, and thirdly on the publie wealth, wherever this mistaken system has been long in operation, let him say who has seen a eountry, a distriet, or eren a single acre which has been the arena of pure immitigated selfishness, on the 
part of its Owners and Oecupicrs, and all who come between the two. The signs are not casily mistakeable;-beggared land, beggared labourcrs, beggared parish-funds, and beggared public finanees can be recognized afar. They reach every sense : the cye can sec it, the ear can hear it, the nose can smell it, the hands can handle it. In time the pereeption reaches the inner senses: and the mind begins to understand that this corruption is the work of mistaken selfishness. The social larrs of Nature press gently and agreeably around a man, till he offends them by long neglect, and the selfish notion that they ean be starred and stinted, harmlessly. Then they eome in foree: and evinee their presence and reality by pain, instead of pleasure. Then the great problems of society begin to work themselves out under high pressure.

In the early stages of the world they are simple enough. When erery man tilled his own ficld, the duties of Landlord and Tenant needed small definition. But advanecment complicates relations: presently the time comes when you begin to sce one man cultivating the soil of another: and that not only without wayes, but paying the owner for leave and license! Mouths have inereased upon the land; but the land measures the same. Aeres don't grow. New 
inclosure cases the pressure for awhile; and like the rising water-mark of a flood, the plough-line steals up) the mountain-side-ligher-and higher yet,-it grates upon the bare rock-and stops. But what has happened meanwhile in the rich valley? Industry, skill, perseveranee, prudenee, self denial, far-sightedness,all, some, or one of these qualities have made individuals-or their lucky heirs-owners of more than they can eultivate themselves. The last bit of moor or mountain-side was the measure of the extreme point at which cultivation would pay : that bit, hanging between earth and heaven, in more than one sense, was the balaneing-point, the test of cultivability. It just pays for tillage; and nothing more. A man perclance may ask your lcave to dig or plough it: but for that leave he offers you no return-no Reddendum -in modern English, no Rext.

Here then is the origin of that eurious thing whose definition has sorely puzzled the Political Economists. And well may it have puzzled: for it is the basis of one of the most eomplicate and peculiar relations that has come to exist between man and man. Mutuality of object, antagonism of interest, upon the same ground, raise a demand upon cach of the partics for one of the most difficult things that human nature can 
be asked for-modified self-interest. It is easy to say that Land may be let like a House, or a Wharf. So it may. But with the mere lease ends all the similitude; exeept sueh as lies between dead stone walls shaped and laid together by human hands, and the living teeming earth whose fertile bosom is impregnate with the perpetual action of a life-producing agency. We talk of the 'eoustituents of the soil,' and something we may know of them: but who can unravel the wondrous tale of their intereourse and inter-aetion, or bind them eaptive to the dry covenants of a motive-ehilling lease? So may a leaf or a flower be 'manufactured,' or an animal 'earved' in wood or stone: but they are defieient in that one element which was said to have reaehed its aeme from human art when the watch was heard ticking in the pocket of the dead soldier.

In a word, briek-and-mortar walls, lath-and-plaster partitions, oak floors, and marble ehimney piees, are dead things, the fitting subjects of a dead eontraet: but there is a still life, a rebounding vitality for good or ill in the Soil,-the glorious handywork of a ligher manufaeture-that will hardly brook the dull sloth of sleeping partnership. Not organized itself, it is yet the aetive souree of organism. Its gifts eome to man 
duty-laden. To take the one without the other is, in the long run, impossible. And euriously enough, the Earth is herself the first witness of a breach of the duties she devolves on and between those who cultivate, or inherit, her gifts, as she was of the earliest wrong eommitted between man and his brother man. She speaks, with most miraculous organ; and tells you the character of the enltivator, or the proprietor, or both, as plainly as your eyes may choose to read it.

Take a walk through an Allotment-gromnd. To an expert cyc, does not each little oblong plot of land, with its varied produce, carc, culture, and condition, tell its separate tale, as if the soil were the destined mirror of the hand and mind of man? Does it need the roiec or finger of the showman to point out the eharacteristies of the several oceupants? Here there is industry, there idleness; here again there is hard labour, witlout skill or knowledge; there you have experimental attempts, despising established practice over much, and ending in failure: here again is toil over-tasked and struggling against want of meansthe spade without the dung-fork-a hard and pitiless struggle; there plenty of manure-heaps, but wastefully and unevenly applied: here again is loss of time upon too close a minuteness and pettiness of eulture, 
there too large and daring a system, which risks the whole spaec upon a single erop. Every variety and sub-rariety of charaeter is self-drawn and pietured on the soil, a photographic portrait of the cultivator. And so it is upon that great Allotment-field-eould one but as casily look over it-the Farms spread, border-toborder, orer the various geological systems of England, Seotland, and Treland.

* * * * *

To this same wide Field, with its many modes of tillage, its various kinds of produce, and equally raried eharacter both of oceupation and of ownership, insensibly flew the thoughts of the puzzled reader of a certain budget of fourteen letters, and of another about the same in dimension, which the following post brought from the punctual Messrs. Penn and Debbitt.

Refleetion might well be allowed to be more longwinded, and Imagination itself to be more faneiful than usual even with the Chronieler, when-arrived at the end of the last of these missires and the questions they contained, as varied as the Postmarks they bore,-he threw his eyes up at a many-coloured Geologieal Map of the United Kingdom, hanging elose beside him, and pietured to himself the possibility, and the value, of just sueh a Map, with its strong 
colours under-shaded by the 'Agrieultural eustoms' that further sub-divide its geological outlines. The eurionsly contrasted interrogatories supplied by the letters he had waded through — for questions are mostly fertile in self-diselosure-would almost have furnished rudely the outlines of such a Map. Perhaps, thought he, before the eentury is out, the dream of 1835 may become a useful reality.

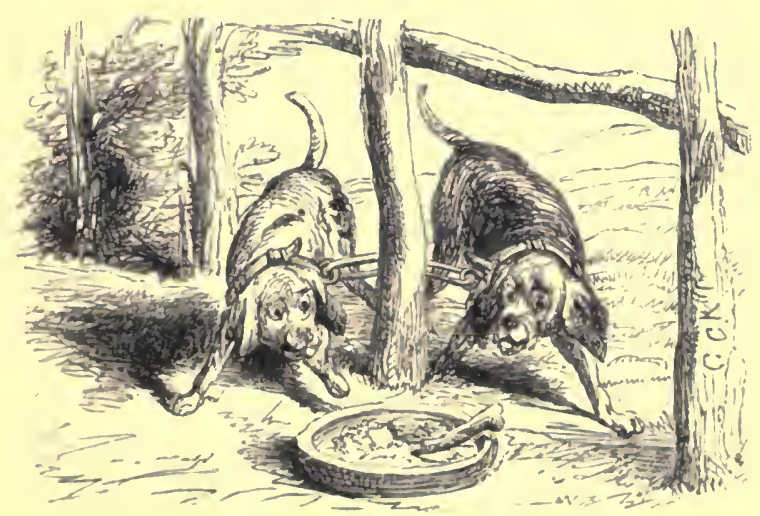

-. In whach there 19 Artasonsm of untercst yct Mat aality of object.'-- 


\section{XVI.}

\section{LOW PRICES AND LONG FACES.}

DAYs-weeks-months-how you drift away! bearing the present time with all its elamorous and busy sounds of life, into that long wake that stretehes farfarther than the eye ean reach-behind us! How you float past-boiling and tumultuous at first, as just escaped from the din and turmoil that marks the everlasting confliet of our onward course-then gently and deceitfully subsiding off with only a rising ripple here and there, that beckons to the eye and tells of something that will be remembered-some duty unperformed-some happiness pereeived too late,-then, at last, sinking away into the smooth surface that stretches far behind in undistinguishable outline, blending near things and remote into one great PAst, and leaving us to wonder at the intensities of fear and hope, of vanity and uscfulness, of evil 
and of grood, with which each moment as it passed seemed pregnant.

How wise we are, as we look back! How clcarsightedly we discover each blunder, and its cause; how surely we belicre that here at least and there at least-forgive us this once, O Common sense and Judgment!- and we will promise never to be such fools again!

Did erer man build a house-or farm a farm-or cren drain a marshy meadow-and not fecl some touch of this provoking after-wisdom that comes too late, telling of material and money wasted--plans insufficiently considered, too hastily aceredited-tiles mishaid, too shallow or too deep, or in the wrong direction? In the matter of brick-and-mortar such aftersight is grown a proverb; and is it otherwise in land? Let him that has never felt it, east the first stone: he has known little of Life's learning who has never repeated to himself how true it is that Experienee is nerer given, but always bought; - at the top price of the market too!

But there is this consoling difference between Bricks, and Tiles, - that is to say, between Building and Farming: that whereas in the former case you always find your cost in having donc too much, proceeded on too 
large a scale-in the latter case you mostly find, such at least was my discovery-that your unprofitable expense is for ever pecping out in the niggling nature of your plans-ficld by ficld, hedge by hedge, drain by drain, a tank here, a cowhouse there-you have waddled through your Farm, denying your better instincts, resisting the true ceonomy which would have prompted a complete and comprehensive plan that looks the whole matter in the face at once: as though a man should build a mansion room by room, and paint and furnish and roof them in, one by one, solemnly counting the cost all the way, and shutting his eyes to the conviction that the next room-and the next story, must come at last,-_and that one roof, one plan, one outlay, the cheapest because the most compendious, might have corered all, and saved the worry and mortification of jobs undone, arrangenents altered and blunders deplored.

Architects are expensive things it is true-but still the comprehensive plan is the eheapest in the end. We want Farm-architects. Not (Heaven help us!) that we want more cxpense in farming, or in farm buildings, but a kind of lnowledge in the whole laying out of a farm, analogous to that of the arehitect who plans a building. The Landlord, the Tenant, the 
Bricklayer, the Carpenter, the Workmen, and last not least the gaping Neighbour-each has his opinion, and gives it freely enough. The result is generally a mongrel compromise between them all. No one voice -no one plan is predominant, and by the time the whole outlay is expended, the job is half a job, and the ship is spoilt for a ha'p'orth of tar and an ounce of oakum. 'The extreme of cold, as well as the extreme of heat, will leave a blister on the fingers.

Five months hal winged away-and the glorious spring of that cightecn hundred and thirty odd, afore dated with such edifying minutencss, and now hanging up like a cobweb in some neglected passage of this Chronicle-had fallen into something more than summer-sinec the Wetlandshire Mereury had typified to the world at large that a certain farm was to be let, at a certain time. 'Fourtecn' applications by the first post, duly forwarded by the prompt Firm of l'emn and 1) cbbitt- (and how many more by the next-and the next-what boots it to particularize ?) had been forwarked in vain. For a blight had fallen-the strangest of blights ! - the blight of Plenty, orer the sons of the soil, and before September had erisped the morning air, and the partridge-chick had found cool midday 
eovert under the young turnip-leaf, every eounty journal had its broad page of 'Sales of Farming stock' set in types in whieh he who ran might readsomething more than met the eye.

"r

Fallen upon bad times !-all up with farming,

I doubt, Sir !" said a muffled roiee, out of a redstriped neek-warmer; joggingly: for the utterer of the sentiment was on a rough nag, not a 'good'un to look at,' but he went - as an old eloek does, by habit -with an ash stiek steadily going, for penclulum, on one side, and a spur peeping under the left gaiter, and steadily going too, on the other, for regulator.

" All up with farming, I doubt!"

And the speaker threw an eye sideways to one who rode on his left, as he repeated the last words,-an eye most expressive-for with the good natured 'erow's foot' that nestled elose up to it and seemed to tell of homefeelings and fire-side memories, there was a momentary wrinkle, a peep of something well aeeustomed to eoncealment, that glaneed out for an instant-telegraphing (how rapidly !) a half eentury's experience of the words 'From the Sweat of thy Brow shalt thot Eat Bread!' Yet not eomplainingly : too truthfully and heart-whole for that.

No answer eame. The ash stiek went on steadily : 
and the spur; for the tail performed the part of index -a true tell-tail, swishing and signalizing to each application of the blunt rowel upon the same spot, grown horny and resistful under its influence. The mouth that had spoken dropped into the neek-warmer again-and the kind but care-full cye looked straight forward, with its fellow, into the early morning fog that lay upon the road and fields, and dripped upon the hedges, where the gossamer had hung its tiny tissuc, waiting patiently for Sumrisc. Click, click, click, click, went the aggravating off-side hind-shoe, for half a mile nearly, before another word was spoken.

"Any chance of its rising again, d'ye think, Sir ?"

Still no answer. The question could not have applied to the Sun, for his red merry countenance was already beginning to peep, immensely large, orer - hill, like some welcome-faeed friend, half behind the door, glowing with the knowledge how the heart of him, or lier, who sits within will rush to tear away the screen that separates them. It conld not be the Sun: for he is half up now, and yet no answer from that thoughtful-looking Quixote, who sits his mare as if he was riding in a dream, and had lost the power of utterance. It was strange, too; for he had 
been no moody eompanion from the time farmer Greening's trotting nag overtook him on the road; and if he had been, Mr. Greening wasn't the man to have hailed him in the merry way he did, and espeeially in such times: he would have gone by with the respeetful, and self-respeetful, morning salute of one who never intruded, nor retreated, on life's highway, in the matter of eompanionship. But that questionWhat was there in it that had stopped the way-eheer of diseourse, and set one of the parties thinking like an oraele? It was lueky that his mare happened to make a false step as he turned her from the footpath where she had been nursing her hoofs, for it made him wake up, and say, "I'm not sure, Greening, that I ean answer your question, but I ean tell you how I answered one of the same sort a fortnight ago, to a man who eame to look at my vaeant farm."

"Oh! I heerd of it, Sir, I heerd of it! They was telling of it the other night at Bogmoor: and didn't tell it bad either: old Dobson said the West-eountry gentleman stood up to his full height (and he wasn't a short un either), and says he, 'Pray, sir, how many bushels of Wheat will this farm grow to the aere?' pompous-like; and says you, drawing up queerly (and, beg pardon, you ain't a very tall un), and looking eal. 
eylating and confidential-like, 'From fifteen bushels to fifty,' says you; and we all laughed, for we knew your look : and I know'd how you'd say it, and what you meant, pretty well. Yes, yes! I hecrd o' that. He didn't like it, however. I think if you'd 'a' said thirty he'd 'a' had the farm."

"No!"

"Not? Well, I don't know. Dobson said he seemed smartish like, and he didn't mislike the look o' the stubbles, nor the rick-yard neither. What did he say to your crop o' Swedes in the forty-acre piece, the Brickfield-close I think you call it? Didn't he think them big enough?"

"He didn't tell me: he couldn't, indeed: for he only looked over the hedge at them, saying that 'it wasn't a Turuip farm.' $\quad$ s he spoke to himself ratlier than to me, I didn't gainsay him. But as it takes me a long time to say anything smart, I aceppted that as a notice, and prepared my answer for what I foresaw was coming when we had done riding through the stubbles: and as I think his hoofs were on every aere of them, I had time enough for preparation."

A short silence ensued. The ash-stick and the spur seemed to work less emphatically. 'The horses dropped into a walk: they were nearing the town of - 
which began to loom through the morning mist. The approaching termination of the ride seemed to bring the two saddles eloser together.

"I think I know what you mean. I had an inkling of it before, when I heard the story from old Dobson; but I see it plainer-like now, after what you've said. You likes a man as thinks of grace before meat," said Mr. Greening in a sort of under tone, and looking up into the face of the otlier, significantly, and with an expression of half inquiry.

"You've deseribed it more shortly and better than I could have done; you've hit the nail on the very head," said the other.__ "I don't know low it is, Greening, but these dark misty mornings bring some thoughts into my mind that I hardly know how to tell exactly as I feel them. But this I know, that some of the thoughts they bring make me shrink from the very sight of a man who looks at nothing but the Wheat stubbles. I'd as soon ride this mare straight into the knaeker's yard"

" Luor' blesh ye, Sir !"

"Well-you understand me; it's but a young one, certainly, for that last journey ; but I should feel less sin or shame in that, than in letting a farm to a man who looks at the stubbles first, and the Turnip-fields 
afterwards, or not at all. The knacker has an eye for a horse".

- "For the dogs"-

"Exactly! and so have some men for a farm. It does seem to me strange that all these pamphletwriters and law-makers should have omitted thisbut I forgot-I am afraid you and I are not quite on the same bench in that question."

"Ah! don't 'e say so! I should like, uncommon, to have a bit of a talk with you, though, about that. It beats me entirely when I hear tell that you ar'n't — that you go with them there Free-Tra-"

"Take care! take eare!" said the other, turning quickly in his saddle, as the fore-horse of a wagonteam turned suddenly at full trot down hill from a side lane into the high-road, grazing Mr. Greening's unspurred foot with the point of the leader's streteher, and bringing the whole team, and the wagon after them rumbling round the corner, a very near shave and at the imminent risk of spilling a sack or two of Wheat that lay not very safely on the near-side shel'board.

"Ay! there ye go," said Mr. Greening, rather angrily, as his hot and rough-eoated nag jumped with some alacrity against the pathway out of reach of the 
wheels, pressing the other rider pretty elose to the diteh, as the wagon passed on before them- "there you go Mr. Cropfield with your new wheat and your Straw again! I wonder how many sacks to the acre you've grown upon last year's Oat-stubble this time! Do look at the boultings, Sir! That's for litter for the team I suppose! He's late to market with that load; no wonder the' go so fast. Well, if it ain't enough to make an honest head aehe to see that!" added the indignant farmer, in a tone of unusual sareasm. "That's what I eall taking the new-laid eggs to market, and the hen along."

"Wheat on an Oat stubble!-He brings back manure, I suppose?"

"Ay, for the Barley-crop; or Oats again, may be: it's all the same: lhe counts back'ards; he begins with the grain, and ends with-no he never comes to the green. He says stems pay quicker than roots; and Stoek's expensive; so he starts at once with the high figures-though, my life! 'tis but a low 'un now, for that matter. Do you think, Sir, it'll ever get up again?"

"The old question again! I'm afraid, Greening, you'd never hear out the answer, even if I could give it. Sharp questioners are impatient listeners." 
"Oh ! trust me for that: if you'd spare me the ral'e of a half-hour's walk through those Swedes again (I should like to see how the dibbed ones get on), I think I can take all you'll give, and ask for more after."

"Oh, you're most welcome to see the Swedes: you 'll come round to the dibbing, depend on it, and when we 've done there"-

"I shall come round to something else! Ah! that's eapital! No, no, no !' said Mr. Greening, laughing and suddenly bending his pony's shaggy neck with a jerk of both reins towards the street that led into the eattle fair, for they had reached the town, and the turn brouglit the eolloquy to an end. "Well, I shall keep you to your promise, Sir, howsomerer. Please to look out for a trespasser on Monday morning! you'll be most like to catch me early. I hav'nt forgot your words last autumn about the matty-what was itthe mattytynial hours."

"You'll be my fast prisoner to luncheon-time. Well, good day, Greening, and a good Fair !'”_ Al ! those 'matutinal hours!' I repeated to myself, as $\mathrm{Mr}$. Greening's good-natured face nodded away, and the ash stick and the well-worn spur, and the eliek, elick, elick, of the hind hoof were lost up the street, towards 
which Nelly swerved sympathetieally for a pace or two before she swung again into her usual trot, and forgot her little rough-coated eompanion.

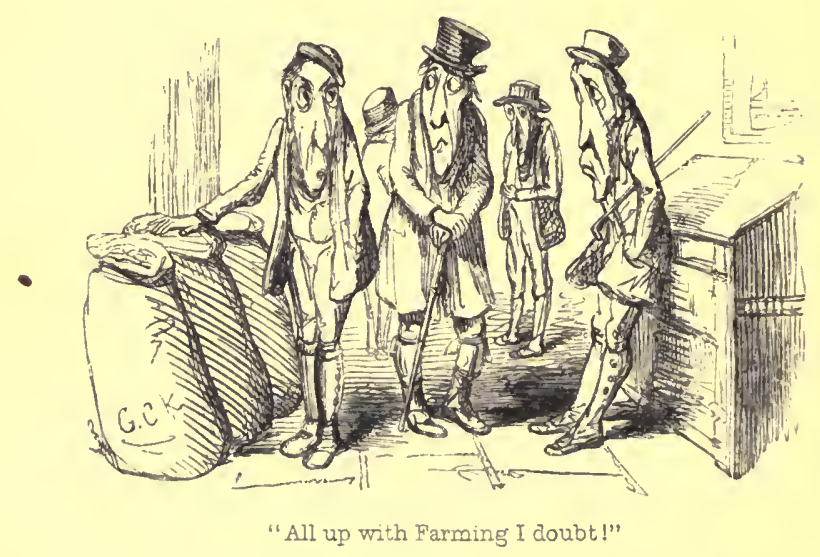




\section{XVII.}

\section{A 'MATUTINAL HOUR.'}

IT requires no small experience of life, to fully realize the often heard and often repeated truth, that 'everything goes by comparison.' When the philosopher tells us that we only know the true value of a thing by the want of it, he merely reasserts this fact. We judge only by the light of eontrast. A man who has lived all his life in England has no adequate coneeption of the English climate. Ineluding with it that of Scotland and Ireland, it stands alone in the world -in that part of it at least which most travellers visit - the Continental world. Its sudden smiles and sudden tears are something truly hysterical. Like some fair maiden who weeps she knows not why-then stops and smiles a bit-a fiekle smile - then falls to weeping again; there is no knowing when or where or how, to be up to all her moods. She is the very April among nations. The Barometer, a tolerably steady-going guide 
elsewhere, she turns into a perfeet laughing-stoek. Fourteen times out of fifteen, it is said, she makes him play the fool. He is like an old Pointer-always making a dead set at a dead seent, or-at notling; - a disap-pointer indieating that which was,-and is 110 longer.

Is it a vice or a virtue? It does not eome for nothing. It has its meaning. It is not sent 'promiseuous-like' to worry and perplex "us fools of Nature," for no objeet or intent. In lier trickiest and wildest and most fantastic frolies, Nature is full of soul, full of deepest, and aye! of most loving purpose, manward. Under hotter skies, where the flesh of beasts is not so much a food as an unliealthy stimulant to the blood, and where the eool vegetable and farinaceous diet are all that man's strength or warmth or' appetite requires, ' eats and dogs' indeed do sometimes eome rattling down for days together; . but they eome in a pack, full ery : or in equally expressive Indian phrase, it pours 'monkeys with their mouths open' when it pours at all. But the gentle English sky alone ' rains Turnips :' and English Legs o' mutton, and Englisl Roast-beef, were assuredly eoneealed behind the veil of eenturies, when the first daring mariner, as old Herodotus tells us, 
was scared back by the 'Fog and falling feathers' from the sacred eoast of Albion. Far away in the thirsty regions of the South, as sun rolled after sun, in dry and blazing sameness through the sky, unscreened by the merey of a single eloud, I have gasped and pined for an English wetting-for one day in the most dripping eorert-for the murkiest downpourfor the darkest elouds that ever gathered in gloomy eomeil over a November day,-till the very memory of it seemed like a dream too delightful to have been ever true! And often sinee, when the very drainers - (and they stand the waters from above the firmament, and under it, pretty well)-have east up furtive cyes out of their soaking trenches to see if 'the Master budged,' giving sundry hints that 'it's a'most time to give in,' I've stood my ground for hours against the weleome fog and shower and darkness, from the sheer inward foree of well-remembered contrast, determined to have it out with Nature, and come to a final arrangement-a sort of water-lerel with her, for having been eheated out of two or three English winters. And I sometimes think she has whispered me a secret, in return, abont those dark and mis-abused Norember days-as she is prone to do to those who perserere with her-which have made 
me prize her, and them, and the land they love and lave, the better; and feel that there is a rough poetry and truth in its iron-grey mists and showers, which have made true of the Farmer what was said of the good and brave man under life's trials :-

"He does not run all helter-skelter To seek a temporary shelter;

Nor does he fume and fret and foam

Because he's distant far from home;

For well he knows, eaeh trouble past,

He's sure to find a Номе-at last!"

It was to some sueh inward thought I was indebted, -and as a faithful ehronieler I ought to tell it,- - for the eourage with which, after tossing off the blankets an hour earlier than usual, I threw my window open to-such a Monday morning! pre-falsified by the brightest stars and elearest sky that ever elosed the day of Christian Rest.

One universal soaking drizzle seemed to have takeı secure possession of eartl, sky, and the day. The small rain gathering on the trees dripped larger from leaf to leaf, falling in the most hopeless and measured way, taking it easy as though for a week's continuance, and no hurry at all about the matter. $A$ single red streak, mueh too red, lay along one part of the horizon, like a long-drawn smile, pregnant with mali- 
cious warning for the afternoon, and killing the faint hope that elings to 'twelve o'clock' as an alterative.

Now for ny promised trespasser among the Swedes! No need for man-traps to-dlay in that quarter, thought I, preparing to meet the foc, with a pair of gaiters that seemed made for the Slough of Despond. The turf-ground weezed and yielded under erery footstep, plainly dating back the rain to an early hour of the night, as I made my way to the field; and as my eye seanned its whole space over, the vietory of the 'carlybird' seemed assured-when suddenly elose to me, fiom the other side of the hedge, just where the master-drain opened out, -came a ringing "Good-morning, Sir !" into my very ear, and Mr. Greening, rising from the bent posture in which he had been serutinizing the drain, looked with mischievous unconcern the victory he had promised, and aceomplished.

"Not deep enough!" quoth he; laconically.

"Which?"

"Oh-the Drain-not yon; and as for me, I was deep enough! You thought the drop' o' rain had stopped me: no, no! I like a rainy day, to see this sort o' land. 'These are laid at three foot! Four's better."

"You really think so?" 
"I'm sure of it! But I thought you was all for the deep drain? I licerd so, long afore I tried it."

"And that's why these were laid at three. This lower part, up to yonder oak-tree, is the first field I drained: and if you had secn the work I had, to get dowì three fect

"Oh! ay, ay! I remember now you mention it. Well, I like the four-foot. But not too wide, mind! I'll allow any man to tell me how deep to drain, if he'll leave me, on my own sile, to say the width. It's a pity to spare a line or two o' tiles, to run a risk."

"Well : this is three feet, by twenty-one in wilth : down the old furrows, in fact. And the worst of it is, it drains extremely well."

" 'The best,' you meall?"

"The worst!-The good done by the shallow drain has been, in practice, the longest enemy of the deep one. A man who finds his field improved by the shallow drain, holds that as a fact. When you tell him that double the depth would have more than doubled the improvement, he treats that as a - a theory. A preadrul thing, that Theory! I wonder how many who use the word-ab-use it rather-know the meaning of it. But what say you to the dibbing?" "Well, they're very reglar: hardly one missed. 
But I don't like to see 'em quite so high out of the ground. I faney it makes a tough skin, and a bitter one. The drilled uns don't look so reglar, but they seem to hold the ground better. How's it done?"

"By the acre; after the first ridging-up, unmanured; a boy goes first, pressing the dib in with his foot. You shall see it presently; it is held by both hands at the top, with a spoke out for the foot, just abore the ball of the dibber, to mark the next distance as its point meets the ground, in drawing it out, sideways, in going along. The hole takes abont a halfpint,--more it should be. The women follow with the manure in a sort of hopper, toss a can-full in, which fills the hole, and drop the seed in. It is done rery quiekly; but the mixing of the manure is the great point. You must eome and see it done."

"I should like it better for light soils. I doubt its auswering so well on this kind," said Mr. Greening, thonghtfully, and poking his stout stick under a turnip which rose very slowly and reluetantly out of its bed. "What is to be done, Sir, with these Clay Siles!-I like 'em-I own I like the strongr sile best -but what's the use o' liking what don't pay? 'The labour's double: ererything's double expense on 'cm, and the time less to do it in : for drain 'em how you 
will, you can not make winter work on 'em, as you can upon the light. Now don't you eonfess that?"

"Ah: thereby hangs a long tale! Chemistry on the Light soils-Mechanics on the Clays! When will that great 'Chapter the Seeond' begin to open? We haven't quite found out everything yet, Greening ! There's something to come, I suspect, upon the Clays, that will startle you and me-wise as we are-some day. "A thing to dream of-not to tell." But eome -you must put the Beans, meanwhile, against the Barley."

"Well, that's true: but that won't mateh it, I'n afeared; not by a great deal. Here's Wheat now down at five-and-thirty! Egad, I ean't give it away! and I remember my poor old father,-and that's fiveand-twenty year ago, in the war-time,--as the bushel o' Wheat dropped into the sack, saying to me, 'There's a guinea, Ben!' and 'There's another!' as the next fell in; and so it went on. That was farming, that was! I'm blest if I don't think they got their own price, and ours along!"

"You've hit the very truth, I do believe: they forgot to take their share of the per contra, when the war was over. They made $\mathrm{A}$ wiLl, bequeathing that to us ; for that, I imagine, will be the end of it." 
"What's the use of making a Will, when you've nothing to leave? They should have left us another war, and short harrests; that 'ould have done better than any laws, I fancy, to keep up prices."

"Postponed the change, perhaps; not prevented it: it was ineritable some day. The fairer course would have been to have aceepted it when it fell due, and begun afresh, with some of those guineas in hand that you speak of."

"Well: it has been but a crumbling wall for" twenty years, erer sinee the War ended, with now and then a bit of a check, in spite of all the laws to prevent it: and these three fair harrests have laid us now as flat as we eould he, if the worst had eome to the worst."

"It secms then that to inherit a falling market is worse than to be born into a low one. You're but right. The latter admits of hope; the other is eontinued mis-calculation, and disappointment :-and something worse than either."

"And what's that?"

"I won't tell you till after breakfast! Come, you old Grumbler, it's the driest subject in Creation, and will take you three eups of hot eoffec to get it down. You shan't eome into my Sauetum with those bootsboots! why, they're like barges, sunk to water's-edge ! 
You're like a eertain Mr. Demos of Athens whom I fear you never heard of-

_-'Twas ask'd through all the quarter,

Came you in Boots, sir, or in Boats-

By Land, sir, or by Water?'

off with 'em! they shall be cooked, under the mutton chops, and come in again with the muffins! You're in elose custody; so pecl off that patrimonial-looking great-coat, and send it after the boots. Why-it's as heavy as-those same guincas! I'll be bound the lining's stuffed with 'em!" [Mr. G. eyed it over, and shook his head, smiling grotesquely.] "Well! eome along-you shall abuse the 'Furriners' and Free-traders over the first two eups, and we'll drink 'Better prices for '36!' over the third."

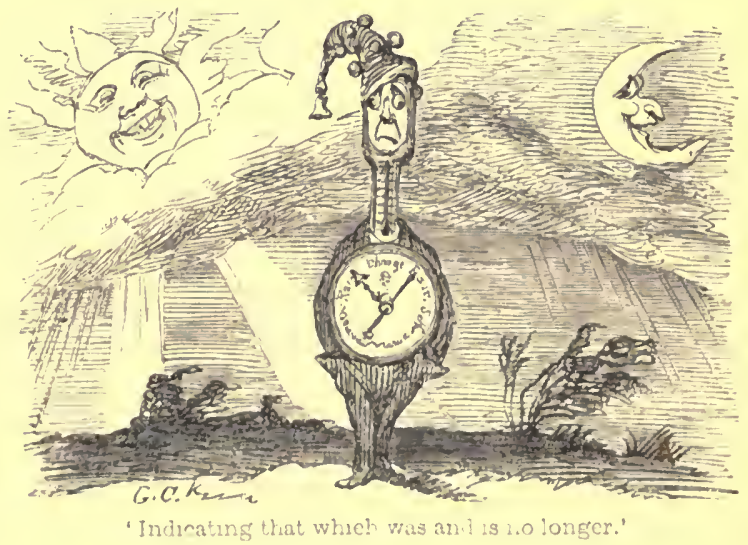




\section{XVIII. \\ 'TALPA' LOQUITUR.}

Amoxg the various experienees which the much more social $\Lambda$ griculture of the last twenty years has brought, (for a great ehange has eome over us in that particular since-well-never mind how long ago I was going to say,-) there is none whieh has struck me more than that part of its philosophy which consists in the operation of mind upon mind. That of 'mind upon matter' is not a very new subject: we see it erery day,--and hear of it too, till it is something tiresome : just now we are on a different theme, and a less trodden : 'mind upon mind' is onr point at present, and perhaps the more important, of the two, after all. I was going to say that in a pretty long and intimate experience of a rather curious soil to deal with, and to which never did man, horse, or implement, deny the epithet 'stiff,'-I too, like them, have had my own 
dumb reflections, and not the least emphatic of these have grown out of the everyday phenomena of mind acting upon mind. You tell a man something, today, or cxpress an opinion, or assert a fact, about a thing which he has perhaps never noticed, or never heard, before; he smiles, starts, shakes his head, or delivers himself in some other way, for the ways are various in which men 'behave' (as the chemists eall it) under the infiltration of a new idea. Whaterer the mode may be, one thing you may be sure of, that in the grunt, the smile, the laugh perhaps, in fact whatever it may be that meets you, the attitude of mind betokened is that of-dissent. I am far from complaining of it: some of my best hands have given me infinitely the most mental gravelling in this respect. But what I do complain of, and want to know where to apply for remedy, (sinee the Law tells us that for every Wrong there lies one)-is that these same hard-lieaded fellows, workmen, neighbours, friends, kind advisers, or whatever other relation they may hold,-six, twelve, or eighteen months afterwards, coolly come to me, and with all that air of profound thought that becomes a man of reflective character, down-calving as one may say with something intensely wise, amnounce to me in language of their own, 
the very thing which $I$ at such time back suffered a small martyrdom in the vain endeavour to urge upon them.

I know not whether other 'employers of labour' have felt this sort of paulo post futurum experience as I have done. But I suspect so; for every man is (and it is comforting to think so) only the unit of $a$ class. It is difficult to study for years the character of a soil, without learning something of the character of those employed upon, aye and even of those who visit, it. And this has been my especial grievance, and one which 'Time, the 'smooth-handed god' has inereased, not lightened. People who derided my ' improvements,' laughed at my 'deep' drains, bewept my grubbed-up ash-stumps, mourned over my obliterated hedgerows, turned up noses at my 'Tank, listened with mock-gravity to my 'mysterious' remarks about the 'economy of warmtlı' as elieaper than the 'equivalent in food,'-and a great many other things that it would take an inventory to tell, -do now come and preach to me such admirable sermons on my own poor old antiquated texts, that I should really begin, as other worthies have done before me, to doubt my own identity,--but for a little store laid by in a corner, of the eapital I began with, 
and which I commend again to all beginners-namely, of philosophy.

"The mind," says an old author, "like the body, must digest before it ean 'assimilate.' The hungry dog bites your fingers as he takes your morsel: but the food beeomes flesh, and the want is forgotten,witlı the giver."

And so I have found it: and so, no doubt, have others. No sooner is a new thought imparted, than it sets up for itself, and denies its pedigree. "Why, that is exactly what $I$ told you three years ago, when you eame-\&e.__!' you feel on the point of rapping out, struek with amazement.

Spare your breath! and your reproach. He cannot remember anything but what he now knows. He forgets that he ever thought otherwise! Tell him, now, something new, and you will see again the same derisive smile, the same look of idle wonder, aye of eontempt, at your faneiful, ideal, 'theoretic' notions : and twice twelvemonths henee, when your idea has taken root and beeome a faet, the seene of to-day will be aeted over again. Then go to your Library,-large or small,-and look back over the listory of the world; and you will see that the annals of human invention and diseovery are the true history of Mar- 
tyrdom, and that to be stoned by lis own generation, and worshiped by the next, is at onee the penalty of human pioneership, and the reiterated monument of liuman folly, dotting the road, like milestones.

It is very fine, no doubt, to eonneet one's own small-seale improvements, after this fashion, with the history of the Great and Dead, to whom life was one confliet with ridieule and eontempt-a history the most affeetingly interesting-perhaps the most important that is left to us;-but after all, the grandeur or pettiness of the scale does not alter the argument. And when I had listened for half an hour to Mr. Greening discoursing of Guano and Superphosphate, in as easy and as matter-of-fact a style as if he had regularly earted them out of his farm-yard on to the turnips any time this fifty years, (though he still ealled it Gu-anner, and would not have it at any priee as a word of two syllables,) I eould not help mentally amusing myself with thinking of the time when he used to poke every imaginable joeularity at me for 'sowing the sawdust,' 'wheel-barrow farming,' ' poeket-dungearts,'-and a whole heap of good sayings whieh, duly noted down on my part, made my ehroniele of that date a eomplete glossary of farm-witticisms : and eurious it was to see how the memory of former in- 
eredulities had passed away from him. My deepest drains were no longer deep; my largest fields no longer 'to' big for the farm.' But Greening was a true improver notwithstanding. He baptized every new-born notion with a jest, but he watehed its growth and adopted eaeh youngster in sueeession, and so heartily and praetieally withal, that they seldom got into his hands without thriving better after all than they had done in mine.

Ye ardent Gro-aheads! who expeet every new argument to tell at once,-every intelleet to yield at the first onset, every new plan to be tried by every body, -learn to wait: and you will find that there is mueh more ehanee of your notion being overtaken than overlooked, much more likelihood of your having to re-claim than to re-assert a single hint that was ever good for anything. The seed may seem a long time buried, but if it lave any vitality in it, it is germinating where you little think, and will fruetify when you least expeet, and with a produee you had never dreamt of. And when you come again and say 'this is mine!' do not be surprised if shouts of louder laughter greet you than even befell your first announeement of it.

I had time to think all this: for my guest, like a 
shrewd bargainer, as he was, gave a little fling to the general discourse before he eame to business. In fact he had the true diplomatic tact of always making the business come of itself. "Well then! Here's 'Better Prices for 'thirty-six'! and that's with all my heart, and no mistake," said he, 'topping up,' with a final cup of Coffec, that healthiest and purest of mortal meals, a plain but hearty breakfast. "And now, Sir, —when are we to see 'cm!" he added, giving his chair a shove sideways, slapping his hands on his knees, and facing me, like a lion refreshed: "for it's my notion we never shall again!"

"And then_—?"

"Why the farmers 'll be ruined, and the land 'll go out of cultivation."

"And the Landlords__?"

"Will follow, of course. They depend upon the Farmers, and the farmers on the land."

"And the land on the price of Wheat?"

"Surcly."

"Tell me this, Greening, have rents risen or fallen since the War?"

"Risen, certainly ; and too much, to my thinking."

"And the price of Wheat has been falling: from eighty or ninety shillings a quarter to forty or fifty, 
as we remarked this moming. Rents rising, and priees falling!"

"Aye! and the farmer's business getting worse every year. 'Tisn't like what it used to be."

"Just so! and eompetition keeping up the rents notwithstanding !"

"Aye! that Competition! It didn't use to be so. And what is it after all? No sooner a Farm's vaeant than a hundred fellows eome yelping after it.like a pack-o'-hounds, offering a high rent, and not one of 'em perhaps with the valye of a team o' horses of his own, searee: and when they get in, what do they do? Crop every field that 'll bear a erop, sell all off for a few years, and then leare it elean beggared, and the landlord without his last year's rent p'rhaps."

"No Turnips-they take no root, Greening!"

"Turnips! they've no stoek to give'em to! What's the use o' them growing Turmips? that's not their sort o' business."

"And they outbid the honest enltivator, and the skilful one: in faet they ean afford to do so, beeause they ean afford to rob: just as though a man offered you a ligher rent for your house, meaning to sell of $\mathrm{f}^{\circ}$ the furniture?"

"That's just it: that's just what it is, surely." 
"And the ligher the price Wheat is kept at, the better it pays,- the greater the premium, in faet, on that kind of 'farming,'-the higher the sham-rents offered orer the head of the fair tenant,- the smaller the inducement to stearly and fair cultivation,--the greater the breadth of Wheat unfairly grown,- the greater the consequent glut upon the corn-market, and the injury done to the honest grower who has earned one large grain erop by growing roots and fecding plenty of stock, instead of raking the land by frequent and diminishing erops with no stock at all. Is that to your liking? Will you pray that the indueement may continue of that style of farming? of that style of competition? of that style of rent-raising, that ends in ruin to the beggared land, the ignorant landlord, the foolish tenant, and the defrauded labourer?"

Mr. Greening looked thoughtful,_-“Well-there's something in that, perhaps; but how's it to be stopped? How's them sort o' farmers to be put an end to?"

Now it was the other's turn to be a lion. So the savage beast sat right opposite to poor Greening, and glaring fiereely in his face growled out-" Now look at me like a man-don't faint-and I'll tell you.- 
By serving them as you do the Rats when you take the Rieks away! Starving 'em out! There's no other way! They'll starve you if you don't starve them. Their food-their only food is-ever has been -the premium price-the disproportionate value of the grain-erop. TAKE aWAY That BaUBLE!" quoth farmer Oliver-the Protector.

There was an 'awful pause.' Mr. Greening was looking into the fire. One would think there was something written in the live embers which he was trying in vain to decypher-so hard he looked at it. - "Ah! I've thought o' that!" he slowly muttered at last, as if to himself:-_"Kill or eure! But tlıat's "kill first and cure afterwards.",

"Kill the proud flesh, to cure the sound. Yes: cruel work, no doubt, at any time; but crueller when done at the wrong one."

"When's that?"

"The moment when it will be done; as surely as effect follows eause! Does it need a ghost to tell us that that time will be a time of scarcity-a famine perhaps, or a fancied one? Then it will be done, and done in a hurry too! And then_W What eomes after a famine, Greening? What is the recoil of Searcity? -Abundance-very true:-then will be the tug of 
war, then! for good and bad together. 'A eruel brute, this Lion,' we shall say! and yet he pastures on the eruellest of all: he eraeks the bones of the true blood-suckers; and 'when it's bad weather for thicres,' they say, 'the true man may sleep the sounder,' let the rain rattle on his eorn-stack how it may. 'Let Mr. Lion roar again,' you will say, wheu you're seen the end. Eren your tiny Mole is a ruthless beast of the field-to slugrs, and suails, and eaterpillars, and such land-sneking fry-a ficree subnavigator, in his way: but his track turns ıp some pretty eultivation; it only wants spreading,-far and wide! it's not so wise to throttle him as you think. I griere to see him hanging gibbeted-lis elerer paddles stopt, by eruel ignoranee. For he is your only granulationmaster; he taught us drainage-and sub-cultivationand we shall learn of him another, and a greater lesson, some day, and eall him a prophet-when we've done hanging him-and have got some speculation in our own eyes (whose sense is shit at present), instead of saying he ean't see. Day and Night! HE has the better right to say so of us !-But as for this price-ofcorn question-this grain crop versus Gieen croptrust me, Nature has lier true Proportions-and is pretty rigorons in maintaining them : and you eannot 
throw them out of gear, but she'll be down upon you, somewhere. Green-crop versus Grain-crop! Which would you show favour to, if either? the man who eomes to make an investment-to earn a erop, knowing the eost, or the spoiler that eomes to take one, counting nothing?-him that eomes to sow before he reaps, or him that eomes to reap before he sows? Do you remember what I said about 'Grace before meat." "

"Yes, yes! I remember it, I've thought of it too, though I never did in that way 'xaetly before.-I see your meaning, now. But-but-about the-What was it you said about the Rents?"

"Ah! the core! the vital point-is n't it? touch it tenderly for the life of you!"

"But will they fall?"

"Will they stop rising a bit? Catch that fish first. Get him well on the hook: land him earefully; and you won't have quite an empty basket, I ean tell you. I'm not sure if it won't take eare of itself afterwards. Which farm pays the best rent, even now, the one where the highest was promised-or the other?"

Mr. Greening drew in his lips and shook his head. "Let the Landlords answer that. "'Taint all gold that glitters.' "' 
"True: so for those that can't distinguish, a pure curreney were the greater blessing, clı?"

"There'll be less of it, I'm thinking," said Mr. Greening, "if it comes to that. But that aint all. There's them Clay Siles. We haren't done with them yet."

"We haren't begun with 'cm! We know nothing about them! almost absolutely notling! We know that they are stiff to the plough and sticky to the flock; positive to the Bcan, and negative to Barley; costly to drain, and, without it, profitless to farm. We blunder on, with just these two or three negative dogmas on our tongues, and are satisfied to think them knowledge enough. The truth is, we have everything to learn about them. I say again we haven't begun with 'em! But come, I'm out of breatl. 'After breakfast sit awhile,'-we mustn't ride the old maxim to death. Let's go and look at them: I can grive you your choice-Red, blue, yellow, and white, and erery one with a different temper for every month of the year! The man that ean tell what is to be done with with them-"

"He's the 'coming man,' I suppose," said Mr. Grecning, laughing, and beginning to pull on his 
great eoat; "he must be able to mix Fire and Water first, I'm thinking!"

"And make Stean?"-said the other.

Mr. Greening turned short round at the answer, as he was going to the door, and looked a moment fixedly at the speaker. Both smiled: but there was a difference in the smiles. And they walked out together.

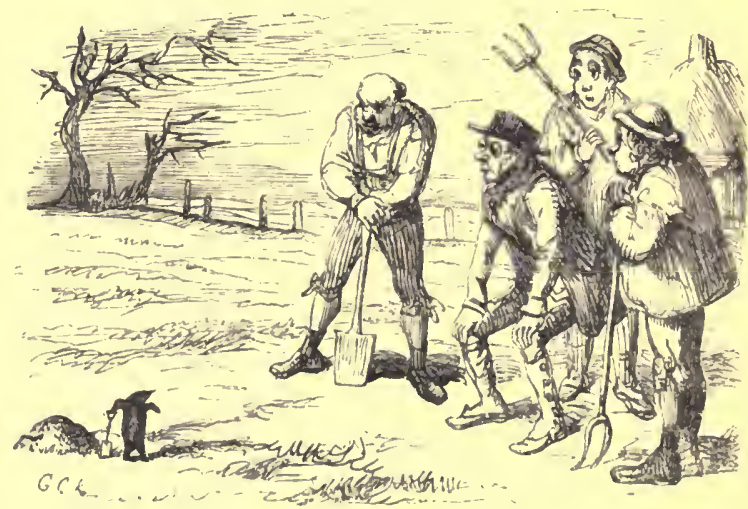

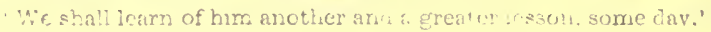




\section{XIX.}

\section{THE ' POWERS' THAT BE.}

Tue eoneluding words of the eonversation which had taken plaee between my worthy guest and myself orer the breakfast table, gave us both an inelination to go and look at the ploughing. A Wheat stubble which had been just drained was being broken up for the next year's Turnip fallow. It was a stiff and rather thin soil, which had, to my long remembranee, been year after year suffering a continual loss, of that kind denoted by a deposit of fine sand at the bottom of each furrow, agrainst the lower headland, from the silting away of the lighter particles of soil with the surface water that ran down them. I used never to look at it without asking myself 'How many hundred years has this been going on? and what must be the amount of deterioration of texture (to say nothing of loss of manure), which this ficld has suffered in the aggregate? Query-Would it be as stiff a soil 
as it has now the reputation of, if it had not been always parting with its sand by this continual process of superficial scraping?' When I eame to drain it, I found that my suspicion was correct. Every here and there the subsoil was ehequered by little 'pots' of pure sand, embedded in red elay, and so full of water that the drainer was obliged to tap them carefully to prevent large masses breaking off and rushing down with the fluid that burst out of them when the sides were eut through. The effect of the drainage was already most remarkable. The workmen called it 'beautiful;' and though nothing can present a more dreary look than a fresh drained ficld with all the cold varicties of subsoil lying exposed along the lines of the drains, I could not help feeling the truth of the expression applied as it was prospectively rather than to the actual seene before the cye. It was 'beautiful' in the same sense that many a roughlooking act, and many a painful soul-subduing thought, and many a rainy day of life's adversitics, is 'beautiful'-by its consequences; and I always liked the word, so pregnant with faith in what is unscen exeept by the mental eye that 'views the Future in the Instant.' Inexperienee or ignorance would have ealled it intensely ugly, and would have pre- 
ferred the previous smootl surface of the ficld, dank, cold, and intractable as it was. What a pleasant effect upon the broad field of society it would have, if a few furrow-tiles could undermine some of the cold stiff surfaces one mects with here and there, through which nothing penctrates-in which no genthe plant takes root-while the lighter and better particles Nature originally gave, keep silting away, as life adranees, learing nothing but a hard and ehilly surface growing colder and more impassive every day to all the grenial influenees which shower warmth upon the heart that will but expand to and aceept them.

"Well! You are a-going deep to be sure!"- said Mr. Greening, following the fresh-turned furrow, and picking up an antedilnvian lump of subsoil now and then, and erushing it between lis fingers. "Why there's plenty of sand here: this 'll be mild enongh for anythiug presently; you don't eall this a stiff soil :"

"It has lain like a stubborn brute that woukdu't risc, for work or play, ever sinee I have known it. It won't know itself next year! It has nerer borue 'Turnip or Barley, sinee the l'lood-which, in faet, it has never reeovered, I suppose, till the drainingtools have bled it in this way. How little one can say what a soil is, till it is drained!"” 
"It does one's heart good to look at it now, however," replied Mr. Greening; "doesn't it make you happy-like to see this sort of ehange, and feel that you have done it? it does me."

"So happy, that at the end of a winter's day of draining-work I have spent hours of delicious idle reverie, with the Lamp wasting beside me as I sat alone, dreaming the day's work over again ; seeing, yet with closed eyes, the long pent-up poison oozing away down its narrow ehannels,-poison no longer! and thinking of the future showers that will percolate and filter through the loosened soil and subsoil three or four feet deep, like some freed and gladdened thing, doing its bounteous Maker's bidding. I hardly know how to deseribe the sense of high privilege the thought brings with it - of being allowed humbly to aid, as it were, in Nature's glorious development. I know of no pleasure that surpasses it-or should sur. pass it-exeept one-exeept one-exeept oNe !"

"Goodness help us! why that's three!-And what may it be, after all, that lifts the knoeker so many times for one visitor?"”

"Look here, Greening! do you see that poor fellow eracking his whip over the horses in that lounging devil-may-care fashion? It's his first year at plough : 
he was 'kipping eraows' for the last two or three. Is n't that a proper amusement for a thing with a human skull, and a real live human brain inside it? That's a promoted seare-erow! Does n't lie look happy ?"

"Well! he's a right to do. He's doing his duty, is n't he, as well as you and me! You ean't do witlout him."

"Ah! yes,-yes! that's the answer. He's a maehine_, driving a machine."

"Well-no-not exactly that, neither. They tell me a plough ain't a machine. Come, I have you there for once, however. A plough's only a tool."

"True, true : a tool worked by horses, and dragging a man after it. You never spoke plainer truth, Greening! And here we are somewhere near the middle of the nineteenth century, and talk of agrieultural improvements! It shames me to think of it."

"What, ashamed o' the plough! O dear, dear! Well, I a'in't, and never was, nor never shall be, neither, that's more."

"Too much, a little. How do you know you never will be?"

"Not, however, till something- Oh, ho! I know now what you're after. You're a-driving now! 
Ay, ay! Now I think of it-they tell me you're always a-driving somehow against the plough. Well, what's the matter with it? So long as it's a good 'un, mind! Come now, I should like to hear from your own lips what you 've got to say agin' it. I ean not understand them books, so it's no use trying; and I do try, that's a fact; but as sure as I get lialf' way down a page I go to sleep. A lot o' Chemistry and stuff! I'll back Common Sense agin' Chemistry any day. But I should like just to hear you on a bit about the plough-I think I could understand that; but you must please keep the words close-cropp'd you know,-no raspers! A farmer's words should be like his hedges, I always think,-plain and short and smooth-like, and not too many of 'em! and then they may help to 'fill the bushel' after all, p'rhaps. But about the plough-beg pardon-you was a saying something

"No, no! go on, Greening! I like to hear you."

"Well, I've done, i' faith! elean out, like. I'm your listener for half an hour-more, if you can spare it." "Can you promise that? I've had many a useful hint from you-Could you sit and listen to my nonsense now, just for half an hour, straight on end-no snoring allowed, mind!-and what if I were to read 
it, instead of speaking? Now don't be frightened! it isn't a book-only a few sheets of paper poked away in a drawer somewhere, and seribbled over: fancy it a long letter from your ever affectionate brother beyond the sea, or a notice from your landlord that he's going to lower your rent, and giving all his reasons for it. Don't you think you could keep) your eyes open ?"

"Well, I think I could. But I hope it's in 'words o' two syllables:' that's all I bargain for; and I'm your man, now. No time like present time!"

A few short steps homewards; a long rummaging over a drawer of papers; a great deal of settling down comfortably in arm-chairs; and, I'm afraid, a couple of eigars, followed this sudden resolution; and Mr. Greening looked wide awake, as the other easting lis eye rapidly down the pages of a manuseript, which looked as if a swarm of spiders had erept out of the ink-pot and been playing at leap-frog over the paper, -clcared his throat and began reading his

\section{'Private Notions on Cultivation.'}

'There are three kinds of 'power' employed by man. The first is manual power, the second is animal power, and the third and most reent, is mechanical power. Each has its own peculiar mode of action; 
and rcfuses to adopt that of either of the other's. The power of a man, from his erect figurc, and the direction of his spine, acts most effectively in lifting. When he works at a winch, his greatest force is in lifting the handle from its lowest point in the circle, to about half way up. For the same reason, in pulling at the oar, or towing a barge, he inclines his figure as much as possible in a direction perpendicular to the stress. In digging, he lifts the soil more than the plough does, and in pressing the spade into the ground he still employs perpendicular force, limited only by his weight. Manual labour is in fact most powerful in perpendicular action.

'But when the man gives up the spade, the hoe, or the flail, and employs his horse to eultivate or thresh for him, a new dircetion of applied power takes place. The baek-bone of the quadruped is horizontal, not perpendicular, to the ground: and the adaptation of the power must be aceordingly. The horse cannot lift and press the implement of cultivation, but he can draw it along; so the spade and the hoe are turned into tools of draught, and are drawn through the soil, raising it with the spiral-wedge-like action of the plough, very damaging to the subsoil upon which the whole stress and hardening pressure 
eome, but eheap and expeditious compared with the spade, so far as regards the mere inversion, or partial inversion, of the soil; though doing little towards its cultivation. Again, in threshing, the applieation of the horse's power must still be horizontal, like his figure, and lis work be done by lateral pulling. The direction of animal power, in faet, is horizontal: and horizontal draught is the only form in which it ean be applied*.

'But dranght is not necessary to cultivation, nor' is it even desirable. The plough, the harrows, the seuffler, and the horse-hoc, are but processes rendered necessary by the only possible mode of applying lorse-power to the turning and breaking of the soil.

'Mechanical power is totally different: and has no more business to be applied to the plough, than a horse to a spade. When horses have leen taught to dig, the steam-engine may perhaps be taught to plough : but nothing will be gained by either; because it is Not THEIR MODE OF ACTION, respectively. The laws of Matter and of Motion are imperative; and pay no serviee to the dull-eyed prejudice of man. Mcchanieal power has many modes of action; but

* Except in the case of a turnspit dog, or a squirrel in a eage, where it is applied to generate circular motion. 
whether wind, or water, or steam, be the driving agent, the favourite motion is the vertically-circular. The horizontal water-wheel is good, but extravagant, and of limited application; but it is worth mentioning as a singular exeeption. Where steam is employed, vertical-cireular action is almost universal. Instance the steam-paddle, the serew-propeller, the common fly-wheel, the locomotive, the eircular saw, the drum of the threshing-machine, the steam pump, and many others that will occur to the recollection of the engineer. When we plough the sea, by steam, we do it with the cireular blades of a paddle: why not the earth? When we eut wood into saw-dust by steam, we do it with the revolving teetl of a circular saw; why not the clod into soil as fine, by the same mode of action?

'What has the laborious dragging of a plough to do with steam-mechanism, whose mode of aetion lies in rapid revolution, which applied behind your locomotive (which must travel forward on the liard soil), could cut a trench a foot deep, and witl its casehardened tines, rasp away the soil from the land side to any pattern of fineness, as easily as a saw can cut a board-taking a modcrate bite of six or eight feet wide as it goes' - 
"Gently over the stones!" said Mr. Greening, as the sudden crash of a fallen tumbler woke him up, and the opening door amnouneed the entry of luneheon __" a bite six feet wide!' my leart! who was it took that, Sir! What a happy-tight he must have laad! What, luncheon a'ready! well, it's uncommon interesting, I'm sure. Why, you'll be quite an Inventor! It's for all the world like what my little girl reads out to me o' nights from her 'Life o' Columbus'-somewhere in the berinning part, where he talks to himself so, till they all thouglit him out of his wits. I'm blest if it a'n't just like Columbus, as diskivered America.-You ought to take a pattern out, Sir."

"Did Columbus take out a patent, Grecning?"

"Oh my! that's capital! a pattern for America! Well, that is a good un, however; no, no, I guess his diskivery was a little too big for a pattern'Wide as a world and broad as 'umanity', as our parson says-No, no! he died quite the wrong side () money-making, now I think of it._But I wish you 'd a' talked it, now, instead o' readiny : for somehow the soft back of this chair o' yourn, and thatwhat was it-piping-Dickler-ny heart! what a word that was; it sent me right off wool-gathering-I 
knew it would! I just shut my eyes to think it over a bit-and I was off like a shot. What is the use o' them long words-they're just for all the world like the Spanish onions,-ha'n't half as much flarour in 'em as the little uns. That's what comes o' travelling abroad now! Blesh ye, them Romans and Antidaluvians as you 'a' been amongst, don't know no more about farming than a lot o' eoekney tailors, for all their long words. Now do just try, Sir, if you ean't slice it up like, into small uns, so that a plain man can understand it-",

"And make it so plain that every one as he reads shall think he knew it before. Well-eomewe 'll talk it over in plain English after luncheon."

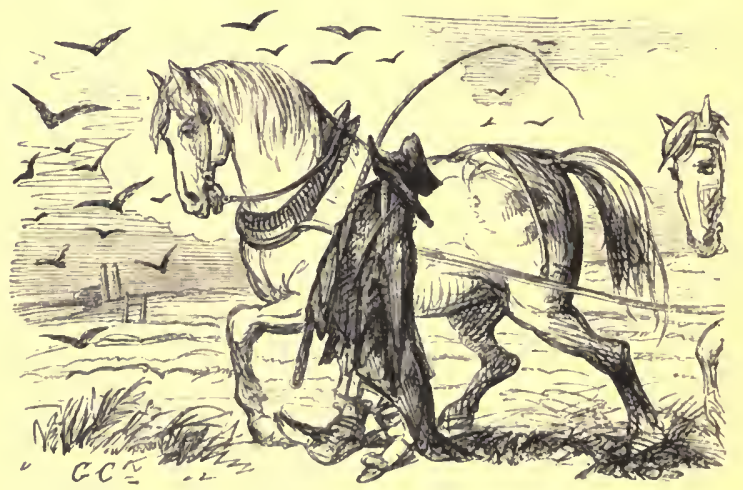

'It's his first ycar at plough: he was 'kupping craows' for the last two or three.' 


\section{XX.}

\section{THE PLAIN 'ENGLISH' OF IT.}

Wнат a eurious, eomplicate, half-interesting, halfprovoking problem is that presented by a shrewd, practical, experienecd, and well-poised mind, without education. Of course I am not speaking of that edueation which every aetive mind, learned or unlearned, is daily picking up, from the first entranee into real life, till 'the night eometh when no man ean work'; but that particular appropriation of eertain early years to the school-room proeess, (such as it still is!) by which the mind is kneaded, and tempered, and subdued, during its only plastie age, into that peculiar tilth and texture, whose after-benefit is known, not by the acquisition of the preseribed formula and rudiments of knowledge, but ehiefly by the having learnt the art of learning. If the knowledge that is earried away 
from school, or college, wcre all, Heaven help our First-class-men and Senior-wranglers! But if you want to know the real value and blessing of that tedious opcration that secms to cut up our early libertics, for so many ycars, into 'morming and evening lessons,' wateh the efforts of a naturally strong and gifted mind, struggling in the after-years of life against the stcrcotyped effects of carly neglect.

There is no class, probably, in socicty, amongst whom more striking instances of this occur than the agricultural : none, perhaps, in which there is less of what is called 'book-lcarning;' none, ecrtainly, in which there is more of natural shrewdness, and a sort of furtive observation which shrinks from being itself obscrved, paying the tribnte of a kind of seeret intelligence and appreciation to qualifications and attainments which it never affects, and, to the carcless eyc, appears to despise. But it diseriminates nicely. For Nature is a schoolmastcr that teaches withont spelling-books. To the husbandman, toiling carly and late, her rede gocth forth, but not in speceh nor language: it inwardly informs : and as the teacher teaches, so the scholar learns.

Such was the case with my good friend Mr. Greening; for I have tried to delincate his character, 
which was an admirable type of a elass still little understood, and caring little to be so. I knew that he would be 'aslecp' during my sermon 'on cultivation :' and he knew that I knew it; and would not have been awake under the aftliction of so many long words for his life and eliaracter's sake. But to sleep without an eyc or an ear left for sentry-duty-that was far from Benjamin Greening. And I; for my part, was satisfied with my audienee; the more so, because I knew that I should find in him an objector, who would not fail to start every difficulty which feigned ignorance, or practical kuowledgre, was likcly to suggest.

Mr. Greening, howerer, was taken with a long fit of silenee. Lumeheon eame and went, and that preoccupying subject he discussed amply and scriatim in all its branches: but I conld sec that my dose was not inoperative. The rindication of his old friend the Plough was hot within hin, the while; strugrgling only with a curiosity to hear the translation into plain english that I had promised him ; and which, he knew, would open plenty of points of attack more assailable than the compact and synthetical plialanx of long words he had interrupted so opportunely at 'the stomes.' 
"So we're not to have a Steam-Plough, then, after" all-eh, sir?" he at last began. "Well, I've heerd talk of it so long that I hardly know whether I'm glad or sorry. But, lor' blesh ye, you go too fast: the Plough's too old a stager to be got rid of that way. Steam I do suppose it will be some day: there I suppose you 're right enough. But if we're to wait till this what-d'ye-eall-it, French-revolution sort of thing, -well-I beg pardon-this merry-go-round Conundrum o' yours [Well, well! whatever it is, then] is brought to pass,-why, it's like waiting for two things instead o' one. No, no! ploughing it must be : it $i s$, however, a'ready ! for I hear talk o' one or two people as are trying it on. There's some lord, I forget his name, has written a book all about it, with a pieture a yard long, where it's all at work as nice as ean be; an engine at each end, and the ploughs a-drawing away in the middle. He's afore you, entirely; for there it is, actshally a-ploughing with eommon ploughs-in the book."

"Listen to me, you old perversity. I have seen that 'book' as you eall it. 'The pamphlet reached me long before you saw it; but not till long after the idea it pourtrays had been as familiar as an old familypieture to my mind's eyc, and bauished, in its turn, 
before ever the engraver's tool had given it ontward form and semblance. If ploughing were erer done by steam, that were no doubt the most obvious way, and as good a way as any. But I hold it (under favour) to be an idea fundamentally erroneous to attempt to combine steam-machinery with the plough. And I hope I am not presumptnous in recording my conviction that until the idea of the Plough, and in a word, of all Draught-eultivation is utterly abandoned, no effective progress will be made in the application of Steam to the tilling of the earth. I repeat what I have said before, that 'ploughing' is a mere contrivance for applying animal-power to tillage. Get out of animal-power, and you leave 'ploughing' behind altogether. Get into steam-power and you have no more to do with the plough, tham a Horse has to do with a spade. It is no essential whatever of cultivation that it should be done by the traction of the implement. Spade-work is perpendienlar. Horse-work is horizontal. Machine-work is circular.

Who wonld now dream of retaining the form of the hand-flail in the Threshing-machine, or that of the oar in a steam-ship, or of putting the piston-rod to work at the lever-end of a pump-handle? Yet doubtless these piebald attempts were all made in 
their day, till the several inventors had come to sec in turn that

"Tis gude to be off with the old lore Before ye be on wi' the new !"

But no one can imagine, without trying it, the difficulty of making the mechanical part of the question intelligible to the agriculturist, and the agricultural part to the machinist. The steam-engine has no taste whatever for straight draught. $\mathrm{He}$ is a revolutionist, in the most exact sense of the word. He works by revolution: and by revolution only will he eut up the soil into a sced-bed, of the pattern required, be it coarse or fine. And that, it is my firm belief, he will be seen doing at a handsome average, before a very large portion of another ecntury shall have passed over. Why should it not be? Why should not a strip or lair of earth be eut up into fine soil at one operation (and sown and harrowed in, too), as casily as a circular-saw cuts a plank into saw-dust? But when you come to employing

$$
\begin{aligned}
& \text { a Steam-engine } \\
& \text { to turn a Drum, } \\
& \text { to wind a Rope, } \\
& \text { to drag a Plough, } \\
& \text { to turn up a Furrow, }
\end{aligned}
$$


and all this as a mere prelude for an after-amusement to all the ancient tribe of harrows, scufflers, rollers, and clod-crushers, to do supplementally the real work of cultivation, it remiuds one of "the house that $\mathrm{J}_{\mathrm{ACK}}$ built." Onc can hardly blame the iron ribs of any respectable boiler for bursting at the first pull, in a task so utterly at variance with every known law of mechanical adrancement, so repugnant to the ceonomics, I lad almost said the rery ethics of the steamcugine.

I trust to be some day forgiven for so boldly speaking; but I am sorry to think of one uscful shilling beingr thrown away in the attempt, unprofitable even if successful, of harnessing stcam with horse liarness, to do horsc's work in a horsc's way; the implement itsclí, whose wretched work it is put to accomplisl, being a tool with sentence of death written upon it (be it as ancient as it may), for its tyramny to the subsoil, which bears the whole burthen and injury of its laborious patl.

I say the Plough has sentence of death written upon it, because it is essentially imperfect. What it does is little towards the work of eultivation; but that little is tainted by a radical imperfection-damage to the subsoil, which is pressed and hardened by 
the share, in an exact ratio with the weight of soil lifted, plus that of the foree required to effect the cleavage, and the weight of the instrument itself. Were there no other reason for saying it than this, this alone would cntitle the philosophic machinist to say, and sec, that the plough was never meant to be immortal. The mere invention of the subsoiler is a standing commentary on the mischicf done by the plough.

Why then should we struggle for its survival under the new dynasty of Stcam? The truc object is not to perpetuate, but as soon as possible to get rid of it. Why poke an instrument seven or eight inches under the elod, to tcar it up in the mass by main foree, for other instruments to act upon, toiling and treading it down again, in ponderous attempts at cultivation wholesalc,-when by simple abrasion of the surface by a rerolving toothed instrument, with a span as broad as the hay-tedding machine or Crosskill's clod-crusher, you can perform the complete work of comminution in the most light, compendious, and perfect detail?

Imagine such an instrument (not rolling on the ground, but) performing independent rerolutions behind its locomotive, eutting its way down by surface 
abrasion, into a semicireular trench about a foot an a half wide, throwing back the pulverized soil (as it flies back from the feet of a dog scratehing at a rabbit-hole): then imagine the locomotive moving forward on the hard ground with a slow and equable mechanieal motion, the revolver behind, with its cutting-points (ease-liardened) playing upon the edge, or land-side of the trench as it adranees, and eapable of auy adjustment to coarse or fine cutting; moving always forward and learing behind granulated and inverted, by its revolving action, a secd-bed seren or eight inches decp, never to be gone over again by any after-implement exeept the drill, which had much better follow at onee, attached behind with a light brush-harrow to eover the seed.

It is hard, by mere language and without a diagram, to describe intelligibly to the mind's eye an instrument that has not been seen; however it may have become familiar to my own. My notion may be wrong, but I am strongly indneed to feel that such an iustrument alone will ever fulfil the requisitions of the steam-engine, which shortens and remodels every labour it undertakes, and never condeseends to old applianees, exeept where they are themselves intrinsieally perfeet in their mode of action. 
Why did Steam reject the Pump-handle and the Oar? Because, in both, the leverage is obtained by loss of labour and time, occurring during the backmovement of the handle, a movement necessary to the manual, but not to the mechanieal agent. For the same reason whenever it is applied to till the earth, it will antiquate every instrument that cultivates by traction, because traction is not only not neeessary to eultivation, but is inherently mischicvous on other grounds, apart from the clumsiness, inaceuracy, and incompleteness of the work it turns out.

But тне Stones! There is mueh fear expressed for the teeth of the eircular-eutting implement I have deseribed, when they come in eontaet with stones. The objection would have been equally valid, at first sight, against the use of the Plough or the Seuffler. Let me see the instrument in use where there are no stones-(and there are plenty of broad aeres in England of this elass;) and it will not be long before it gets upon the others. If it eost five pounds an acre to elear them out, it must be done, and would in sueh ease, well pay to do it. But the truth is that the instrument itself suggests the kind of machime which, with a little adaptation (greater power and slower motion), might perform this preliminary serviee at the 
least expense. If land is to be like a garden in one respect, I sec no good reason why it should not in all. I do not think stones will stand long in the way of Steam, or be readily preferred to bread; if, where there happen to be none, a steam-driven cultivator calz be brought to bear, which, after the simple and beautiful example of the mole, shall play out the long comedy of our present ficld cultivation in a single act, present a finely-granulated seed-bed by a single process, almost at the hour required; and trammel up the 'long summer fallow' into the labour of a day, with an accuracy as perfect as the turning of a Lathe, and an acration (and consequent oxygenation) of the soil as diffusive and minute as that of a scattered mole-heap, or the dust flying from a circular-sawbench.

Implement-makers and mechanieians would not be long in understanding all this, if they were not under the supposition, received at second hand by them, and therefore the more difficult to eradicate, that ploughing is a necessary form of cultivation to be kept in view. Onee let the Q.E.F. be clearly understoor by them; once let them be made filly to perceive that 'ploughing' is merely the first of a long series of means towards the accomplishment of a par- 
tieular end, that end being the produetion of a seedbed, of suitable depth and texture, and with the soil as nearly as possible inverted in its bed-and I do not think they will be long in setting the steam-engine about its proper task, in the proper way. But their attention is distracted, at present, from the end to the means. They are taught to think that the plough is a sine quâ non-that steam-cultivation of neessity implies steam-ploughing, and they are led to give up the task in despair, beeause they are at fault upon a false seent.

We have many rolling implements employed in the field, but we have only one instanee of a revolving implement. The elod-erusher and the Norwegianharrow roll, the hay-tedding machine (one of the best instruments ever invented) revolves. I use the words somewhat arbitrarily, but the differenee I allude to is very important. The first are liable to the evil of 'clogging;' beeause they derive their axis-motion from the soil as they pass over and press upon it. This aetion must not be eonfounded with that of a machine which has its cause of revolution within itself, independent, and aeting upon the soil as a eireularsaw aets upon a board, or the paddle-wheel of a steamer upon the water. The teeth of a saw elear 
themselves, by the ecntrifugal motion they eommmieate to the particles they have detached from the sub. stanee they act upon. A eireular 'cultivator' steamdriven will do the same. It does so more effeetually according to the speed (of revolution) and the state of the soil. This last ineident is as it should be; for it is not desirable that a elay soil should be dealt with when in an improper state for tillage; and one great advantage of sueh an instrument as I point to would be that it would so immensely enlarge the ehoice of a suitable period, by its eompendious aceomplishment of the whole work of culture.

My object, however, is not so much to adrocate the particnlar mode of applying Steam-power which I myself suggest, as to explain the grounds on which I feel more and more strongly assured that the attempt to employ it through the medium of the plough must be eventually renounced.

"There's one thing," said Mr. Greening, who had been listening throughout with unusual attention and persererance, and nodding knowingly at the end of each sentenee, as if the idea was steadily gaining ground npon his mind,- 'There's one thing that you have n't mentioned, and on your own side of the matter, too. The firer the soil's worked down, the 
greater the effect of the manure: of that I'm eertain sure ; large as I like to see the elods on a fallow."

"I was afraid you would have taken the other side of the question on that point," said I, "on which a good objection may be taken,-and answered, too; and which we must not omit: but it was not because I had said my say out, that I eame to a pause; but rather because I felt that there was still so much unsaid, and I am too tired to say it now, and you to listen to it, I should think. Come, it's no use denying it. We must adjourn. Besides, I want to hear your objections. I know they 'll rise thick and threefold, when you 've left me. When shall I hear them; to-morrow ?"

"To-morrow let it be with all my heart! I doubt you've given me a bad nighteap, though! When I get a subject of this sort into my lead, it sings in my ears half the night: and when at last I do go to sleep, I dream of it till I 'wake again. Well! 'In for a penny,' as they say : so I shall be glad to hear it out. Maybe you'll finish it to-morrow. I don't think I shall ever look at a plough again without thinking of you !"

And Mr. Greening took his departure; not more busily impregnated with a new subjeet than lie left me 
with an old one: for of all the powerful stimulants to deeper thought upon a subject in your own mind, what so powerful as the first sustained effort to derelope your antecedent coneeptions upon it by the slow and detailed process of conversation, and that with a not too easy or unobjective listener? Idle and valueless as yet as the unsmelted Ore is the Thought that has not been struck out into the eurrent coin of simplest words. And this once accomplished, who shall say where that eurreney may lead, or in whose hands it may yet thrive, hereafter?

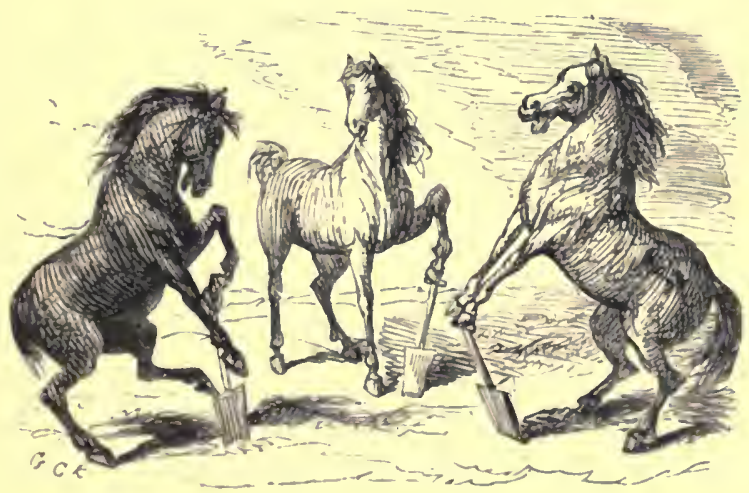

' Steam-power,-no more to do wath the Plough than a horse has to do with a Spade." 


\section{XXI.}

THE 'STEAM-CULTIVATOR.

Wнат an irresistible tendeney there is amongst men to draw each other in earicature. How prone we are to magnify those features in whieh the character of another differs from our own! I doubt not that if Mr. Greening had deseribed our late interviews (" if the lion had been the seulptor") our readers would have been at least as much amused, the other way. I should like much to see the 'per eontrid' that he would have drawn out.

I am justly led to this conelusion because my notes of our further eonversations show how eompletely I had under-rated both his interest, and his penetration, in the subjeet I lad so suddenly broached before lim; taking it too readily for granted, that a thoroughly praetieal man, like limself, could not streteh his imagination to the point required to make him enter into my views, or the suggestions I had made. 
'This was far from being the case. He had heard, I suspect, and interpreted too, after his own fashion, crery word I had said and read to him. For, after our late-deseribed interviews, his 'trespasses,' as he called them, on my Farm beeame morc and more frequent. Whether it was that he thought the demerits and defieieneies of the plough were more strikingly to be seen and freely studied upon my soil than on his own, or whether lie reckoned upon the ehance of hearing them more boldly outspoken, I will not attempt to decide: but for some reason or other I soon found him a frequent, and by degrees a more (if I may venture such an expression) long-winded listener. Not a week had elapsed after our last conversation, when a rainy day drove him into my den for shelter, and as ready a prey as any beast that erer roamed the wilds of agrieultural theory conld desire.

"I'm afeard," he began, after ensconeing himself' in the very same ehair, with one of the very same eigars, opposite the same fireplaee, and in preeisely the same attitude- “I'm afeard it won't leave off" for" some time. I should like to hear you out, Sir, about that Steam-ploughing-I beg pardon-steam notploughing-'cultivation'-anything you like to eall it, that you was on about the other day. I don't 
know how it is, but it seems to haunt me like. You've done me harm ["Hal"?] you have indeed! I used to love follering the plough, and see it heave up the furrow-slice so smooth and niee, and swelling the rich earth as it swam along, better than anything else I know on earth-execpt, perhaps, hearing my little Fanny reading when I come home sleepy at nights,-but now-I don't know how it is, I seem to run my head again' it every time I see it, on stiff ground, a-squeeging and pressing, and kneading its way along: it gives me the very headache to look at it; it does really! Now, please not to mind about the long words, for onee; but let me hear it on to the end. I should like to know the worst on itand the best, if there is any. I want to klow, now, really, why, if Steam's the proper thing-why it has n't been done. They do most things by steam now-a-days: if it is to get upon the fields, why don't . it? What stops it?"

"You have asked," said I, "the rery question 1 ask too-Why is it that amongst all the great inventions of the day, the subject of CULTIVATION BY STEAM seems to hang fire. Not for want of thought upon the topie; for there are many minds full of thought about it, and few people now-a-days believe the thing 
impracticable: indeed no onc can find any good reason why it should be so. There is no particular difficulty or peculiarity about the mechanism of eultivation, to "forbid the banns" between the soil and the steam-engine: it is gencrally felt that the match will take place some day, slow and unpromising as the courtship may seem at present. I join hands in this belief; and in the meantime ask your special attention to these preliminary points, which may help to account for past delay, and possibly to advanec the question from its present silent condition. Silent, because invention is apt to be so. Self-interest keeps it so; and in the meantime a generation may pass by, and nothing be practically done towards a consummation which, once accomplished, it requires no ghost to see that Great Britain would leap aliead in agriculture as much as her mines of eoal and iron, and her still decper and richer mine of mechanical skill and improvement, have led her to do in every art and manufacture upou which the breatl of stean has been brought to bear.

Here in fact lies the grand motive in the matter; and one so emphatically important in referenee to this particular applieation of steam-power-ret to be achieved-that one cammot help wishing that all who 
really think at all about it - who are not of that elass of infidels who think the womb of invention is agestricken, and that notling is possible but what has been done-would eome into committee upon the subject, and abating a little of that exclusive faith which each has in his own eleverness and chance, would help to bring in this tide, as the tide of human progress is wont to eome in-not by one great wave, all at onee, but a great many wares after and upon each other.

There is one grain of eomfort, and of eorresponding hope, visible already. A good many thinkers have got quit of the steam-plough, and got as far as the spade: that is something. It is something, I repeat, to have got to the spade; for those who have got thus far will not stay loug there. The publie mind moves slowly; but onee in motion, the inertia onee shaken off, and the vis inertice onee set agoing, it will never stop till it reaches the goal.

Again and again be it repeated, that it is not plonghing, neither is it digging, that we want. These are only means. What we want is the end: we eare not for the proeess. Give ne A SEED-BED: show ne the soil comminuted, aevated, and inverted, six or eight inehes deep, and I will not ask you how it came so. 
What does that matter? If you wanted your coffec ground for breakfast, to a certain fineness of texture, would you be very particular to ask whether the mill that crushed the fragrant berry had worked by horizontal, vertical, alternate, elbow-erank, or by circular motion? If the farmer or the gardener could only have his seed-bed made ready for lim as fine as a new mole-heap, or to any other coarser texture, aceording as he wants it, do you think he would eare whether the soil had been first eut into longitudinal strips, plough-fashion, or into square eubes, spade-fashion, before it was finally granulated for his use? Surely the one is as indifferent as the other; and singularly enough, both offer problems far more difficult to the steam-engine (if anything can be ealled so), than the performanee at onee of the ultimate and entire proces: without these preliminary forms at all.

Until steam-power was discovered, this possibility did not exist. Wind and water power being ont of the question, there remained nothing for it-no other power that could be taken to the field-but men or horses. Ploughing or digging, then, were the indispensable preliminaries; there was no getting on without them: they were but preliminaries, it is true, the former leaving everything, the latter a great deal (ac- 
cording as the work was done) to be aceomplished afterwards to complete the eultivation.

But it is not so now. Sinee the birth of the steamengine-no suel very long time ago-the whole elements of the question are altered. There exists now a portable power-not limited to horizontal aetion like the horse, nor to rertical aetion like a man using the spade or hoe,-which if mercly told what to do will go and do it, mercly dropping a hint into your ear that circular motion is its favouritc.

But the willing giant stands idly panting and smoking: for nobody ean agrec to tell him what to do. One says, "go and plough!" another says, "go and dig," each mistaking the means for the end, and trying to yoke this youngest born of human genius to the peddling routine of manual or equine eapacity ; out of the very perversity of backsightedness that clings to forms and modes which belonged to the $\mathrm{im}$ plements not to the task-backsightedness that would with equal reason puzzle its brains in looking for the pole and splinter-bar of a locomotive, the pendulum of a wateh, or the paddle-boxes of a screw-stcamer.

But if it is not ploughing, and it is not digging, what is it? "Go to the Mole thou dullard" (the old proverb might be travestied), "consider her ways 
and be wise"-who without any coulter share or mould-board, withont spade, hoe, or pickaxe, leares behind her in her rapid track a finer mould than ever Ransome, Howard, or Crosskill-than ever spade or rake produced, or the most eareful-handed gardener chopped up, to pot his plants with. The very rabbit that seratehes his hole in the ground, or the fox that scratches after him,-like a king-crab, to eat the kernel and lie in the shell,-or the dog that scratches after both,-the whole tribe of "claw-foot" in fact,-had scratched hard carth into soft mould, before ever the plough or the spade, or even the more ancient Hoe, had broken ground on this planet.

Let us begin from the beginning: let us take 'Cultivation' itself into thought for a serious moment, and analyse it into its simplest elements, dropping all conventionalities of plodding custom. What is it? How would you do it, if you had neither plough nor spade nor hoe nor rake to help you? With the same tool that the Monks of La Trappe used to dig their graves, and in the sane manner! If the mole, the rabbit, the fox, the dog, are not sufficient indicators, take the hand of man, glove it with hardened steel, multiply it a dozen or twenty times, till you have an instrument as broad as Crosskill's clod-crusher, 
each hand or claw with its separate arm forming the radius from a eentral shaft, which bristles all around with a forest of such arms, a sort of revolving Briareus, not rolling--let that be especially remembered-but steam-driven, a thousand dog-power if you please, for we must not even mention liorses, or we shall drop back into the old Seylla and Charybdis of 'traction' and of 'rolling,'-two ideas to be eschewed like poison.

Let us suppose the picture of this formidablelooking eylinder of elaws to be suffieiently deseribed, for the moment-reminding one at a distant view, of a half-breed between a liay-tedding machine and a Crosskilu's clod-erusher-but unlike them, fundamentally distinet from any and every instrument that was ever seen afield, as doing its work not by traction, not by its rolling weight, but DRIvex by its axis, as the stcam-paddle, the cireular-saw, the driving-wheel of the loeomotive, are driven, supported by its own apparatus, and abrading the soil with its armed teeth, first eutting its own treneh, burying itself to the required depth, and then eommeneing its ownward task, tearing down the bank (so to speak) on the advaneing side, eanting back the abraded soil, cartlı's sawdust, "comminuted, acrated, imerted" into the trench it leaves behind. 
If I have failed in making the picture elcar or intclligible, it is yet not that about which I care so much, as to "draw aside the curtain." The idea of ploughing and digging stands like a thick blind before the whole philosophy of the subject, and serecns the inventive mechanician from the simple application of his mind to the quod est faciendum. His faculties are clogged, stupified, held in eheck by the pestcring contemplation of processes that enter not neecssarily into the problem to be solved, nor need appear in its solution. They are unessential to the matter. They became so the very instant the steamengine was discovered; a power, and the only one we possess, that can be carried to the ficld, and put into an agricultural machine-like the main-spring into a rateh-to give it independent intrinsic action within itself, owing nothing to, but scparate entirely from, the traction and progression of the implement along the field. Hitherto there is not even the attempt so to apply it ; it has never had a chance. Every fieldimplement we have, works by traction-like the Pcdometer that ticks because the wearer marehes; bnt with steam for our mainspring we can make the watch tick, independent of the wearer. When we understand that, when we have in idea and in fact detached the work of cultivation from the mere pro- 
gression of the implement, made them perfeetly separate and independent, so that if you eeased to proceed, your " eoffee-mill" would still be at work, and only wanting fresh eoffee to grind; then, and only then, shall we have laid hold of the end of the elue that leads to Cultivation by Steam ; for then, and only then, shall we have begun to appreeiate the real and unique value of the new agent we possess. To suppose that it would gear its noble faeulty to the dragging of ploughs, or the redoubled soleeism of a rolling spade-machine, is to transgress the elementary axioms of natural law, the fundamental relations and exactions that govern all physieal progress and diseovery.

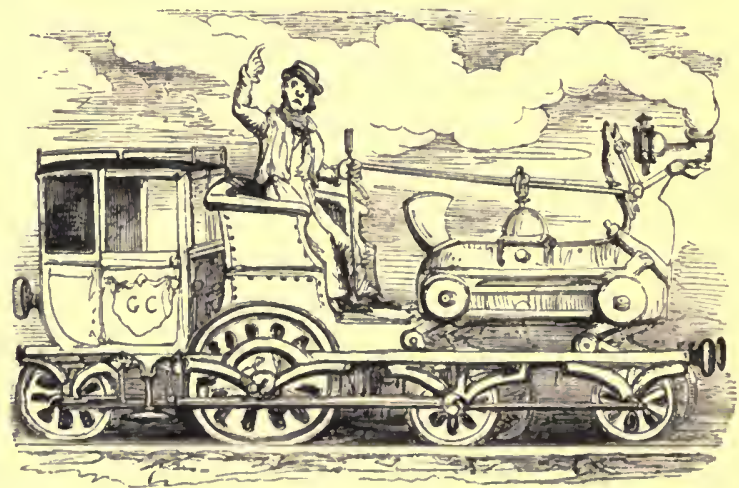

"The wlling grant stands ldy panting and smoking.' 


\section{XXII.}

\section{THE SUBJECT CONTINUED.}

I cas call to mind no practice, in the intercourse with others, more improving, sometimes more humiliating, than the attempt to explain in elear words to a listener, not disposed to give much quarter, an idea with which one's own mind has been long familiar. A large portion of what we call our ' mind' consists of the Imagination, a proverbial deceiver, painting images (as its name implies) upon the retina of thought, apparently all real, but fading into dimness, crumbling often into the utmost confusion and intricacy under the attempt at delineation by the tongue. This is of every day experience. But there is another traitor not so commonly arraigued and brought to trial,-the memory. What has long been on our minds, we are apt to regard as we do those faces that we have met again and again, and only become 
conscious of our ignorance when we have oceasion to address the wearers by name. 'Talking makes a ready man, reading an exact man,' says the old proverb. That laying out of a subject in detail which talking requires, clothing it in simple and intelligible language yet illustrated with analogies and metaphor, suited to the individual addressed, is an excreise in itself susceptible of such improvement that one is sometimes tempted to ask, whether Language owes more to Thought, or thought to language.

But this was not all. In the conversations that ensued with Mr. Greening, derived from my original promise to him to put this question of Steam-cultivation into plain English, I soon felt that it is one thing to sec a matter as plain as a pike-staff before your own eyes, and to put it into language very simple to your own mind prepared to understand it, and a very different thing to make it intelligible to those who have never given any express attention to it before. For the sake of the importanee of the subjeet, I will try to restate the whole question; dropping, for the purpose of continuity, the dialogne form in which the subject was by frequent and uscful objections on his part made to derelope itself.

Before the diseovery of Steam-power, and its appli- 
eation to machinery, there was no such thing as a meehanical power that could be earried about, and applied where and when and how you pleased, except animal power. 'The plough, the spade, or the hoe (with their varieties), were the only possible modes of effecting the task of eultivation. The eomparatively reeent diseovery of steam-power altered the eondition of human life in this particular. The modes of action to which eultivation was before limited, and which are exemplified in the use of the threc instruments just named, became, on the diseovery of steam, no longer the necessary and only modes of performing the act of tillage. From the nature of things it was morally ecrtain that whenever that new Power was applied to this act, it would be through an instrumentality as different from the plough, as the plough was from the spade. If a man will only give himself the trouble to think how total a revolution the application of steam effected to the narigation of a ship, and the locomotion of a carriagc, he camnot very well fail to see what is meant by the saying that a new power requires a new process. It is a solecism in art, as well as scienee, to attempt to yoke steam on to a plough. There is no affinity between them; any more than, as I said before, between a horse and a spade. 
I have found it inexpressibly difficult to get this leading postulate clearly and once for all understood. Till it is so it is hopeless to attempt to proceed. The idea of an instrument to be dragged through the soil, as a plough is, from one end of a field to another, poisons more or less, not every, but nearly every effort towards steam cultivation I have scen. How difficult it is to unlcarn!

When the attempt was first made to run steamcarriages on common roads, it was soon found that however good a macadamized surface might be for a wheel to roll upon, under a carriage drawn by horses, it broke away into a perfeet gravel-bed when the new power instead of pulling the earriage which set the whecls simply rolling underneath, laid hold of the Wheel itself, and produeed the locomotion of the vehicle by foreibly driving the whecls round. The very best road gave way under the severe friction of this new mode of producing locomotion, and so did the tires: and nothing could be done till both road and whecl were made of solid iron. The new power required a new process. Instead of pulling the carriage it drove the wheel, and in driving the whecl it tore up the stones even of a Granite road.

Let us put on our Agricultural spectacles, and apply 
this parable. When Steam-power is brought into the field, (audiat qui aures habet!) it will "play out this play" over again. Its faeulty and virtue eonsist not in pulling vehicles or implements, but in driving wheels: and when steam-driven wheels will tear up granite roads into shingle and gravel, and move the Carriage too, (for so it did, only not fast enough for modern travellers,) what forbids the hint being taken by the "andax Japeti genus," that have happily applied so many aceidental hints before, and the same refraetory giant being set to rasp up eleverly and methodieally with sharpened Mole-like elaws, the tender soil, when he has shown his ability to tear so tough a one with the mere palm of his hand? And what forbids, either, that he should spare off a little of his redundant steam in moving his own earease along, meanwhile, at a paee of little more than half a mile an hour? "What you save in speed you gain in power ;" and an instrument (as broad as Crosskill's Clod-erusher,) which eompletes the whole work of tillage, as it moves along, will hardly be required to go much faster. At that speed it would eorer four acres a day — not of 'ploughing,' not of ' laarrowing,' not of 'rolling,' not of 'seuffling,' not of 'rolling again,' 'cross-ploughing,' 'elod-crushing,' 'rolling 
again,' 'ridging up,' 'sowing,' and 'harrowing in'; but of all these epithet processes in one comprehensive act-and word-Cultivation.

Is it not astonishing, with such experienees as we have before us in England, that sinec the first introduction of Stcam power to the notice and assistance of mankind, nobody has ever yet attempted to apply it in its own way to the definable and simple work of eultivation. It is put to cut chaff, to make sawdust, to granulate powder, to make pins' heads, to reduce all sorts of coarse material into fine-and all by whecls, -circular motion, and nothing clse, for nothing clse will it aceept,--but nobody can persuade their minds to belicre that by the self-same action, and no other, it fan cut up a scam of soil eight inches decp and six feet wide, and leave it behind granulated to as coarse or fine a texture as the nature of the seed or scason may require, and inverted in its bed. It is not ploughing, it is not digging, it is not harrowing, raking, hocing, rolling, scarifying, clod-crushing, scuffling, grubbing, ridging, easting, gathering, that we want: all these arc the time-honoured, time-bothered means to a ccrtain Result. That result is-a seed-bed: and a seed-bed is, simply deseribed, a layer of soil from six to twelve inclies in depth, rendered fine by commi- 
THE SUBJECT CONTINUED.

nution, and as far as possible inverted during the process.

You may eall this 'Theory,' my good Mr. Practical, but I tell you it is Trutn: simple, obrious, philosophical, practical Truth. Since the Imvention of the Steam Engine, it might and may be done at one process, as easily as before in twenty; and it will be. Before we depart this life, we shall see one more wonder moving upou the face of the earth, something of this form and fashion-to wit-a complete locomotive engine on four wheels, the fore pair turning on a transome, the hind ones fixed; behind them (suspended) a transverse, cylindrical shaft, three feet in diameter, from six to eight feet long, reminding one of a cross-breed between a elod-crusher and a hay-teddingr machine, armed with case-hardened steel time-points, in shape like a mole's claw, arranged so that the sidelap of each elaw may eorer the work of the other, and no interval or ridge be left uneut : the extremities of the eylinder just eorering the wheel-tracks. This cylinder of elaws you will see raised or depressed at pleasure by the engine-driver, and adjusted to slow or rapid revolutions, worked either by cog-wheels, or geared fiom the drum of the Engine. That is the "cultivator." A platform from the Engine extends 
over it, ending in a sort of moveable tail-board, which may be raised or depressed at pleasure, to regulate the settlement of the soil which scatters from it. The revolution of the eylinder is not against but with that of the whecls, not dragging or retarding, but rather helping the advanee of the whole machine, which is mored slowly forward by a detached forec of about two horsc-power from the Engine.

When, at some future day, and by some pen not yet out of straight strokes and pothooks, there shall be written, for the edification of the agrieultural public, an historical sketch of the 'Rise and Progress of Steam Cultivation, it is to be feared that some of the reflections will not be of the most complimentary kind to the genius or the faitl of the generation that has cmbraced nearly in one experienee the development of Steam Narigation, of the Railroad system the Elcetric Telegraph, and other kindred applianees in the many-patlicd ficld of practical science.

'It was strange,' we may suppose our future annalist to write, 'that amidst the blaze of surrounding discovery in the arts that economize the labour and advanec the condition of man, an application of steampower that must surely have pressed witl such powerful motive and exigeney on a period when an extensive 
ehange of eommereial policy seemed especially to croke the mechanieal resourees of the kingdom, by way of set-off to its often-urged disadvantages in climate and in fiscal burdens,-should have been long regarded rather with the apatly evineed towards the cobweb speculations of dreaming enthusiasm, than dealt with as a practical question by practical minds. While zealous agriculturists were eloquently exeited once a year over the weight of an $o x$, or the twist of an improved mould-board, 'Seienee' was satisfied, and 'Praetice' seemed to tread on the lieels of perfeetion. Under such patronage, 'Improrements' in the established implements of tillage, were of eourse as numerous as the moiety of twenty aeres of ground could conveniently accommodate for annual Exhibition. A revolution impending over Tillage itself was of course the last thing dreamt of. It is erer so. True, a few black fumels might be seen smoking in the show yard, and the whirring drum of the steamdriven Thresling-machine had, thanks to the previous invention of a eertain Scoteh lawyer, made the agrestial mind forget to expeet, or its prizes to stimulate, improvements in the Flail. But the prineipal and time-honoured act of agrienlture proper, of cultivation itself-still laboured under its aneient tribe of horse- 
adapted implements. The Plough and the Harrow were still in the ascendant: the instruments of equine-tillage were still received as its essential agents; and people who would have smiled at the mechanical curiosity of a steam-Flail, gravely anticipated the day when some such combination would be triumphantly achieved for the darling tool whose Heaven-invoked 'speed' had long supplied the toast and figure-head of Agricultural Prosperity.

' Yet it can hardly be wondered at,' our aggravating Critic will continue, 'that men should have slowly and with such difficulty eradicated from their minds a mode of tillage so long compelled by the very nature and necessity of animal-power: every elild that has wept and smiled over the 'Death of Cock-robin' knows when he hears

$$
\begin{aligned}
& \text { "Who 'll toll the bell? } \\
& \text { 'I' says the Bull. } \\
& \text { 'Because I can pull,", }
\end{aligned}
$$

that Mr. Bull was guilty of a pun; that the 'pull' of a quadruped is only horizontal; that his strength can be applied in no other way; and that when you cmploy a four-footed beast to eultivate the soil you have no ehoice left but horizontal traction, from one end or the field to the other; a mode of action which comı- 
meneed when the spade was abandoned in field-eulture for the plough, and which was to continue so long as horse-power tillage continued : and no longer : sinee it formed (as the spade had already shown) no necessary element of eultivation, and had no relerance whatever with the action or eapabilities of the Steamengine.

'Steam-power having howerer been hitherto ehiefly employed in Manufactures, and its versatile modes of application being unf:miliar to the agriculturist, we ean seareely be surprised, that even those few who gave a serious thought to the subject, looked upon the Steam-engine rather as a piece of eoneentrated horse-power to be haruessed as best it might to the existing horse-worked implements, than as a New Agent, whose entry on the seene of action enabled him to reconsider the whole philosophy of Tillage, to analyse it into its elements, to see what it was; what it had been when eonfined to manual power under the primeral dynasty of the Spade and Hoc: what it was under the advaneed but equally special limitations of animal power, as exhibited in the Plough and every other inplement of draught; and what it might be under the wider sphere of available process which the Steam-engine presented. What was cultivation? Did 
Steam-power offer any cheaper, better, or more direct mode of performing it, than manual or animal power had done? Could it accomplish in one act the problem of converting the hard elod into fine soil? Could it, like the mole, cut a seed-bed out of the solid? If so, why entangle it with implements foreign to its nature, unessential to its action, and behind it in that order of inventive progress whose deep-cut label is 'Vestigia nulla RETRORSu'?

'But the Plough had left its ridgc-and-furrow impress not more in the ficlds than, alas! on the mind of the agriculturist of that day. It was long, and naturally so, before he could bring an imagination preoceupied with the old-established system of fickculture, to recognize its impending emaneipation from the whole chain of subordinate neessities exacted by the employment of horse-labour. The old fable had become reversed: the quadruped was riding the man: and to sliake him off was now the diffieulty! For a ecntury after its invention, the Steam-engine lay stillborn to the soil, and the virtne unappreeiated of a new power which could antiquate mere implements altogether, and convert the cultivating agent into a machine, in the strict sense of the word; a machine whose locomotion across the field was a mere colla- 
teral incident, not a means; as the sheep, or ox, walks over the pasture to crop it, but does not erop it by walking.

'And yet it was somewhat strange, too, that reeognition should have been so tardy, and aceustomed thought so incradicable on this point, when we refleet that modes of tillage already existed, so totally and specifically different in aetion from all horse-worked implements, as those botll of the Spade and its more ancient eongener the Hoe; $*$ and that the perpendicular and very effective action of these manual tools, contrasted witl the farm-implements of draught, might have dimly suggested the possible diseovery of other means of eultivation as different from all of these as they were from each other. Any one who had erer seen a nutmeg rasped away into fine atoms against the armed surface of a grater, or sawdust seattered in heaps from timber by the

* In the Southern Countries of Europe, as in Italy, Spain. and Portugal, and in the offshoots of the latter,-Madeira and Brazil, the IIoe is the almost exclusire implement of (manual) tillage. The Spade is, originally, a form of the Iloe, adapted to more northerly climates where the moistness of the soil increases the labour of cultivation by forbidling the tread of the workman on the worked land, and obliges him to stand on the 'land-side' of the trench. 
tecth of a circular saw, and could find room in his imaginative faculty for the contemplation of this mechanical process, side by side with the agricultural fact that a sced-bed is only a layer of comminuted soil a few inches in depth, might surely (one should now suppose) have saved the eredit of his generation by some more congenial suggestion for the effectuating of tillage by Steam-power, than attempting to bind it down to an apprenticeslip in which Ploughs and Harrows, Rollers and Scufflers, or even the spade, were still to figure as the rude terms of the Indenture, as out of kecping with its genius and aptitude, as they were irrelevant and non-essential to tillage itsclf analytically regarded, apart from its couventional modes neeessitated by horse or hand-power.'

Such will be the kind of after reflection thrown back upon his forefathers of this generation by our future agricultural historian. 'It is true,' he will be obliged to add, 'there were not wanting heaps of patents and pretensions crowding in confused suecession on the public notice, during this period of mental racuity and decrepitude of invention. Whererer there is a lack of grain there are plenty of weeds to fill the gaping space. There were plough-dragging engines, stationary and locomotive, there were 'ploughshares 
on circular frames,' ' rcvolving spades,' and all the train of picbald monstrosities and biform incongruitics that mark those periods of false gestation and miscarriagc in the anmals of invention, when would-bediscoverers, dashing blindfold at unconsidered combinations, are each profoundly busy putting ' new wine into old bottles ;' nerer devoting onc serious hour of study to the simple elements of the problem they undertake,- - the mechanical act to be accomplished, and the mechanical means necessary to accomplish it ; but, (like the scribe Dickexs tells of, who ventured a treatise on Chincse Metaplyysics, by looking out 'China' and 'Metaphysics' in the Cyclopredia!)taking a plough and a steam-cnginc-or a spade and a steam-engine-as the ineritable sire and dam of the fore-detcrmined 'cross,' plunged headlong into the labyrinth of complex and solitary contrivance how to join things which Nature had put asunder.'

- "velut agri Somnia, vanæ

Fingentur species; ut nee pes, nee eaput uni

Reddatur formæ. * * * * *

Infelix operis Summâ, quia ponere totum

Nesciat!"

Such, we may anticipate, will be the storm of keen reflection showered orer our graves by some writer 
of the end of this, or beginning of next century, who looks back upon the origin of steam-agriculture from just such a point as we do now on that of steamnavigation; who will be as familiar with the sight of soil pulverized a foot deep, in one act, by surface abrasion from a steam-driven cylinder [armed with the Talparian claw that "works i' the earth so fast," and solves in the dark, beneath our very feet, a harder problem !] as we are with ships of a couple of thousand tons, driven through the water like a duck with her web-feet at work beside or bchind her, in either case obedient to the steam-law of circular motion.

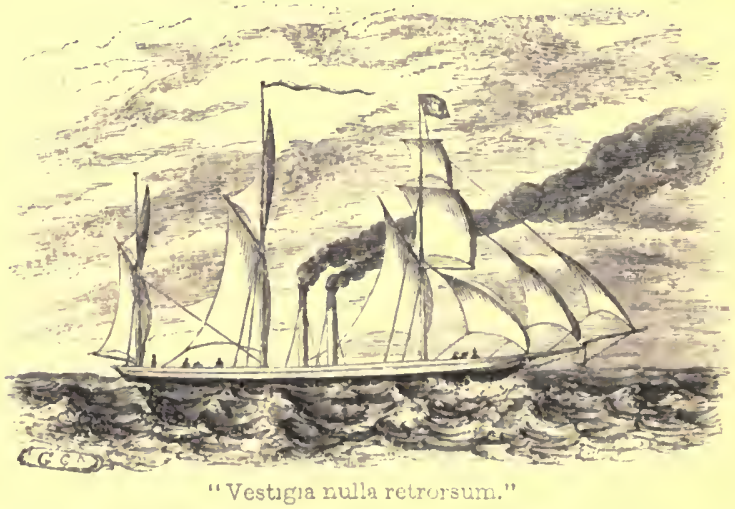




\section{XXIII.}

\section{MACHINERY OF THE CLAYS.}

"Matren is infinitely divisible," says the philosopher. "Cultivation consists in pulveration," says Tull. "The greater the comminution of the soil, that is, the exposure of its internal superficies, the greater its power to absorb Ammonia, the essence of manure, from that great storehouse of fertility-the atmosphere," says the ehemist. "Soils," says the geologist, "consist of three elements, Clay, Sand, and Lime; the more suitably they are inter-eombined the more fertile the resulting combination."

This looks simple enough. Yet in the judicious application of these few truths lie the great practical problems of Husbandry! All truth is simple: 'Simlplicity is the test of Truth.' Yet like the three primary colours, 'Red,' 'Yellow,' and 'Blue,'bright, elear, and simple as they are to the eyc, how 
infinite their varictics of combination; what scope for judgment, or for crror, in their admixture, or that of their Sccondaries; what ample room for blunder, what diversity of apparent 'accident' and mischance, what damage of unlooked-for incident, and unallowedfor circumstance! What open pathless wastes for the blunderer and the cmpiric, what narrow and difficult stceps for the student who has the heart to climb.

Oh Agriculture! thou science of sciences without a School, thou Philosophy without a 'Porch' (cren for shelter!) thou University of uncxamined graduates; all 'Masters' and no 'Students'-when will thy 'degrees' be better recognized, thy principles be more truly studied, thy ' privileges' be better appreeiated, for being the better understood. When will men consent-condescend-to LEARN-an Art that claims a share of light, and illustration, and practical advancement, from erery physical scicnec that has sprung into being, since Bacon traced out knowledge to its source, and Chemistry, THE pHILosophy or MATTER, gave the best of posthumous illustration to that great inductive theory that rests all knowledge on the one sole basis of Experiment.

When that day comes-when the living eliemistry of the Soil is accepter. and understood, not as an 
amusing and probable speeulation, the raguely suggestive subject of a 'Leeture' before a patronizing Couneil ; but as a solid, working-day, every-day practical fact,-then the Mechanies of Agrieulture will not be far behind! 'Then the 'touching truisms' of Tull-the Galileo of agrieultural scienee, the Iuther of modern husbandry, - struggling single-hander against a whole Dark age of ignorance and banded prejudice-will reach the 'promised land' he saw and pointed out with the finger of the seer, but was never allowed to enter. Blending into the truest of union with the after-discoveries of Davy, De Candolle, Licbig, Boussinghault, and our own not less deserving Way, and Johnstone, and others of distinguished note-his theory of 'Cultiration' will propound matter of deep thouglit and combined action equally to the chemist and mechanician.

When the simple mechanical idea of pulveration, comminution, subdivision, or by whatever other long name men may please to understand it, shall be seen in its chemical meaning, as eonnected with the food of plants, the 'pasture of roots' as Jetliro Tull with appropriate metaphor, deseribed it,-then the elaim and application of the Steam-engine will be made out and recognized, and the name of James Watt will be 
found as important to agriculture as that of Humphry Davy.

It is a mere question of Time. We travel slowly : and, like lazy wheelers, throw back our ears and bite the pulling horse: but if ever the shadow of a eoming event was visible beforehand, even to the unimaginative eye, this of the true mechanism of Cultivation is one that is beginning to be visible. Call the Seer 'visionary' if you please. Visionary! of course he is visionary! it is his place and office, his duty and profession to be so, and to bear the eonsequenee! He sees in 'vision :' it is by far-sighted vision that he catches sight of the "man's hand" in the horizon, which others cammot see, and will not believe till it touches their eycballs. And then they will swear they always saw it, and will have forgotten that they ever didn't see it. The mall was nerer yet found that would head a deputation to earry the world's recantation and apology to the derided prophet whose derided propheey has come true. With the advent of the Faet, dies out the propliet's only distinetion,-to be ridieuled. Sueh was ever his fate; and will be, to the end of time; varied only by the politer form and phase that eivilization gives to persceution. 
Yet, in the present active progress of invention, the transition is so rapid between one phase of our industrial condition and another, that the difficulty of inducing men to realize the possibility of a coming discovery sccms almost to tread upon the heels of the after difficulty of recalling the memory of a deficiency that has been supplied. The paradox of today becomes the truism of tomorrow. And in spite of all her wonderful advaneement in arts and manufactures, in spite of all her great names in every department of practical science, there is no country where both these phases of mind apparently so inconsistcnt with each other, co-cxist more pertinaciously, more permanently, than in England.

The truth is that, opposed as they appear to be, they are the two sides of one and the same eharacter, a character eminently and essentially practical, which cannot recognize anything but what is, and will consent to look neither into the future nor the past with a very patient gaze. We smile at the imaginative habit of mind of the German, and the precipitate quickness of the Frenelıman; yet in fact through sheer practical industry we surpass in effective progress the dreams of the one and the quick conecits and anticipations of the other. 
But inestimably raluable in result, this national character makes invention excessively difficult, exeept where it drops in as it were in the eoursc of busincss, suggests itself to the mind of the workman, and in a workman-like way, to casc him in his task, or to shorten a process done for the thousandth time beforc the abbreviating link in the chain of practical cause and cffeet, forced itself upon his notice. Anything like à priori investigation of a problcm,--clcmentary riew of the principles lying at the root of a process, -is the rarcst source of invention. Thus it is that a elever machine makes the workmen cmployed upon it intclligent; as the insect takes its colour from the lcaf it fects on. Discovery follows discovery in rapid succession; and cach room in a cotton mill or manufactory,-wc are informed as wc pass through,presents an accumulation of little additions and improvements, a hive of ingenuity as well as industry, all resulting as it werc, spontancously from the suggestive influence upon the workman, of the machine that at once employs and instructs him.

But it is not so in agriculture. The educational effect of the Stcam-engine upon those it cmploys, so strikingly visible in manufactures whosc date is of yesterday, has licre not yet begun its gra- 
eious operation. Here the new power has not yet eome in to suggest new proeesses. The hind ploughs as his fathers ploughed, as the Roman ploughed, as the Egsptian ploughed: and with even less advantage: for in the dry soils and elimates of Rome and Egypt the plough was an apter instrument of eultivation than in our damp soil under a northern sky.

True, a better machiuery has found its way into the more intrieate task of threshing out the grain, and from that it has still more recently erept, backwards, from the last operation of threshing the grain, to that of reaping it. For it is eurious to notice, in passing, that it has begun at the latter end of the farmer's labour,-a signifieant token perhaps of its nltimate direetion and sueeess, in the earlier details of field work. The Flail was the first to give way : and by the ingenuity of Menzies, the revolving drum of the Threshing-maehine, beating out the grain, by contimous eireular motion, was substituted for the alteruate strokes of the flail, (just as in navigation, the cireular Paddle took place of the baek-and-forward aetion of the Oar,) whilst the horse-power was eoneentrated round a pirot, the nearest approaeh horsepower has made to what we eommonly understand by the word Maehinery. This point aelieved, the 
introduction of the Stcam-engine to that branch of farm operations was at once made casy. The right motion existed before the Steam-engine was brought to bear upon it.

Once let this be done for clay-soil cultivation; once let all that has been said and written, and prored, about the properties of such soil, and the properties of the atmosphere, the habits of plants and instincts of roots, condense into an act of mechanism whosc aim and object shall be the most perfect subdivision that can be effeeted at a single operation; and the conquest of the clays is achicved. It will then be scen that none but a PORTABLE power could accomplish it, that its praetieability lay lidden in the womb of the future, till the Steam-engine appeared, and manual and horse power were sererally disearded, the one to the garden, the other to the road where locomotion from place to place is a real and primary ohject of the power and mechanism employed.

The infinitcly graduated varieties of soil that exist between the lightest sand and the stiffest elay, preventing as they lave done that marked line of different treatment that a more rigid contrast of the opposed qualities of sand and elay would have suggested,-together with the further variations of 'tem- 
per' alternating with the conditions of wet and dryhave been too much perverted to the result of making the agrieulturist a Jack-of-all-trades. He goes out of a light-soil farm into a clay, or vice versâ, and plunges his share into the new element with about as much uneoneern as his wife puts her duek eggs under a hen to be hatched and edueated. Plump goes the little brood of ehangelings into the first pool of water, incontimently bent on their baptism of native mud, to the consternation of the astounded mother, who vainly plies her elaw in seratehing on the sandy shore for unsuited food, croaking out her frantic warmings to the contumacious family of webfoot. With about as intelligent a philosophy as she exhibits under such distressful and hopeless circumstance, has many a plongh been stuck into the elays. But nothing can express the truth in shorter phrase than that of old Dobson.

"I tell you, Sir,-it's a different trade!"

No wonder then that "the best form of the Plough is still matter of disagrecment." It must ever be so, as long as Clay and Sand are things as opposed in nature to each other as positive and negative. A stiff clay under a moist climate the greater its mechanical disadvantage, and its intrinsic ehemical superiority, 
(and both are fully admitted,) the more it seems to call for a revolution in its mode of eulture, for a system peculiar to itself. In the arts, as well as in morals, 'Diffieulties are opportunities.'

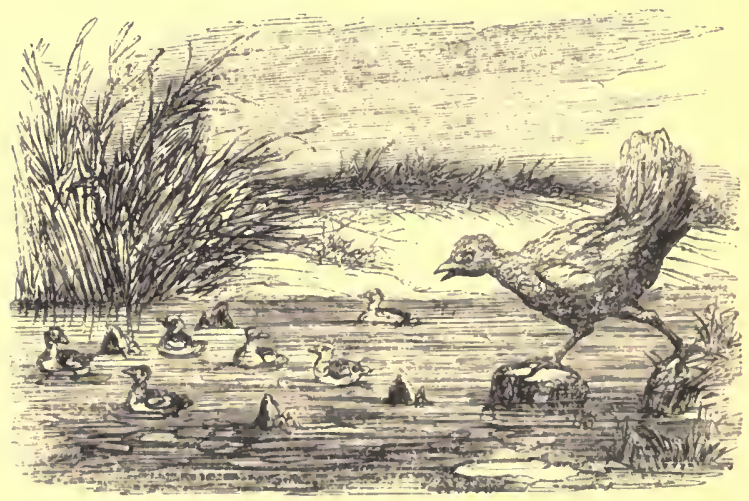

'Incontmently bert, on them bantram of native nud.' 


\section{XXIV.}

\section{CONCLUSION.}

DAY after day, month after montl, year after year, the labour of the Husbandman begins afresh. It is without end, middle, or begiming. It defies all the 'Unities' of 'Time, and Aetion. And as its nature is, so must be its everlasting development, literary as well as otherwise. To give it a somewhat livelier tongne, to reseue it, at least for an oceasional lour, from a tone and treatment which under the boasted title of 'practical,' would seare away from its deeply interesting diseussion all that has adorned, as well as adraneed, so many other equally laborious and less naturally attractive pursuits, was the motive that suggested the too desultory chronicle of deeds, of words, of thoughts, that these pages have imperfectly recorded. A story without an end, a solilocpuy without a speaker, a dialogne without a denonement, 
and, what is worse than all, a 'Farm to let' without a Tenant! Such is the diseursive and informal shape taken, as of its own aeeord, by a series of extraets from a journal extending over many years, and of whieh it will be cnough if he who reads shall haply say, he ' could have better spared a better' tale.

But though it break and baffle every rule of literary eomposition; though it leave every interest unsatisfied, every euriosity unquenehed, let it not be deficient in the one intransgressible rule of Harmony-to end in the Key-note: and so doing, let it speak at least with one eonsisteney, and leave upon the ear one simple and abiding chord that may link it with pleasant memories, and, if more and better yet than this may be hoped,-may lighten and sustain the solitary hour of some future toiler, striving all alone-and far away from suitable eonverse and eneouragement, to solve the tedious problem presented by a diffieult soil, and what is more diffieult than that to eure or eope with, intractable opinions, and minds that no argument ean reach, no evidenee assure.

Bowed by an afflietion, for which life eontains no cure, and ealendaring his remaining years of earthly solitude as a schoolboy marks off one by one the weary list of weeks that must intervene before the 
joyful hour that shall restore him to all he has lately parted from-the writer of these pages was fain to weleome the emprise of a task, which might liave seared aray, as indeed it had done, all to whom life was not so dead, that the only thing that could rise again upon it was-a blister.

Such was in truth the condition under which, to the amazement of that surrounding world called 'Friends,' and the consternation of that critic's gallery, one's own tenantry, I rentured on the solitary occupation of a farm whose desolate and repulsive features have been sufficiently portrayed, and with little of exaggeration. Stecped to the eyes in all those notions of seienee and exactness which a working University experienee, and 'those Temples twain Inner and Middle,' may be supposed to infuse into the brains of younger sons, I plunged into $m y$ task with all that sanguine and pedantic enthusiasm best known, in farming, under the expressive title of 'Fireedge.' "A blessed thing," I have before said, "is the untaught boldness of youtlı!" a blessed thing in its way, and in its time and place. It is as much intended, and has its appointed task, in the great Order and Economy of things, as the most cautious sagacity and profound experienec of advanced life. "There 
is that seattereth and yet inereaseth:" and He who appointed Life as an advancing experience, appointed every part of it to accomplish, and to vindicate, its appropriate phase and character.

So I now feel it, whether I mentally review the enterprisc, labour, and amusement of years gone by, or whether I look over the comparatively reclaimed acres and shrub-embosomed homestead of the once dreary spot it was my privilege to find 'thrown upon my hands' at a moment when the drearier waste within defied the outer landseape. Could the scene be presented to me again with the aspect it onee wore, I should hardly, even with the bought economy of experienee, have the boldness to attack it: but if eompelled to do so by duty or necessity, the only differenee in my course would be a more resolute and comprehensive plan, based upon a decper relianec on the first instinets and judgment, unchilled by the timid and discouraging language which surrounding practice easts, in nearly every distriet, across the path of the improver in agriculture.

Whenee this timidity and this diseouragement?

With the attempt to answer this important question my task shall he concluded; and the personal experienec of a landowner oceupying the most diffi- 
cult of his own farms, and striving to "sound the bass string" of the matter, by assuming the actual circumstance and position of those whose interests it was his duty to study and mulerstand, shall be stated, with such reflection as most suggests itself to one who, while his spare shelves were filling with ' $\mathrm{Ag}$ ricultural journals,' and the works of 'Tull, Mills, Licbig, Johnstone, and others 'of that ilk,' still kept an cye upon his Law-books.

The evil of retarded and diseouraged investment in the soil lies decp, and dates far back. It is not the fault of the Farmer : he is the subject, the time-grown and created result of the Legislation, and Custom with the force of legislation, that have made him what he is, and invested him with a stcp-mother relation to the soil. By the Law of primogeniture applied to Land alone of all other kinds of property and capital, you have set on foot in this country a system which has nearly reached its elimax in the amassing and aggregation of land into the hands of few and large owncrs. The ancient ycoman, the owner of his own farm, is becoming or become an cxtinct genus animalium. By the cnormons and factitions costliness, delay, and difficulty attending the Transfer of land, increasing in an inverse ratio with the acreage (for 
the relative cost of 'title' to an acre is beyond all eomparison with that of a hundred, and of a hundred in like manner witl a thousand), you have secretly elenched and fortified the process which entail and primogeniture had openly avowed and established; and rendered it impossible, on the common principles of prudence or economy, for any one to buy land (except for building) otherwise than in large, and increasingly larger quantities. The tendency is not stationary; it is still going on. The man of small or moderate capital is becoming every day more and more effectually ousted from the possibility of ownership in " the earth," which "was made for all."

You point to France and Belgium, where an opposite law compelling subdivision, with still more evil tendeney exists; and talk about 'political expediency,' and the mischief of 'morcellement.' But must we rush into one extreme to avoid the other? or is our timid intelligence so seared that it eannot pause to distinguish between a tyranny which enforces subdivision, and that middle eourse which would allow Land, like every other form of capital, to adapt itself to human need and circumstance, and wholesomely to exist in great and small proportions? Or is our political philosophy of such a school as to allow the sup- 
position that we have the MORAL RIGHT to 'eapitalize' the earth, and disfranchise seventy-nine eighticths of the inhabitants of this country by 'Aet of Parliament,' and the 'Custom of Conveyanecrs'?- [ for it is authoritatirely said-(and there are no statistics to disprove it !) - that the owners of land do not number above two hundred and fifty thousand, out of a population of twenty millions !]

Mark the consequence. Instead of the soil being, as it was meant to be, the first and best of Savings' banks for capitals of every size; to the Peasant and the Yeoman, as well as the Duke and the Squire, we assume the audacious office of readjusting natural and common right, and pronounce for a system which agglomerates land into hands that may monopolize, but after all cannot themsclies use it, and cut down the whole interest of the rest of the 'agricultural community' to the rank and position of 'Tenant-farmers.' They do not, as a elass, penetrate the meaning or the mischicf of it: they are "to the manner born ;" and think it 'all right' if they could only get 'Tenantright ;' (as if the hirer of an article of limited supply, could hare any 'right' but what the owner may choosc to give lim !)

But then a Lease! What is the use of a Lease 
for the purpose of investment, unless it be of long duration? Nay, it is often urged against leases, that under a good landlord farms pass from father to son, and grandson, better without a lease than with one : then why not as property at once? Why kcep up the form and farce of 'ownership,' if its very exccllence consist in a virtual surrender of its cxercisc, cxcept to receive the 'dividends' half-yearly, under the name of 'Rent,' and pay annually for the 'rcpair' of premises you ncrer occupy?

Not that there arc wanting many instanees of improving Tenants and libcral Landlords. Thank Heaven, the worst laws are modified in practiee by the eommon sense of mankind, as well as the best evaded by its ingenuity. It is the universal and unprofitable substitution of 'tenancy' for ownership, that is here spoken of,-the territorial mapping of the country into dukcries and squiredoms, the impounding of the soil out of the action of frec investment, and the compression of its inviting and unexplored capabilities within the complicate trammels of a fietion,- the fiction of an Owner that docs not occupy, and an Occupicr that does not own.

Why should this be? Why should Law, the instant it applics to Land, depart from its simplicity 
and eren-handedness by making land, alone of all other forms of property and eapital (that fall under its occasional operation by intestacy or disputed right), an exeeption to the general rule of fair and cquitable division? In the freest of all frec countries, where freedom is 'the law of the land,' why should not 'the land' itself be free? Why is it that so few will take the pains to understand the question cnough to sce that 'primogeniture' is a thing which families may make for themselves if they please, like heirlooms; but which the Law has no more to do with than with the deseent of my Lady's Jewels to the next 'my Lady,' though under the Statute of Distribution of the effects of Intestates, they would have been treated as personalty, and divided aceordingly.

Again and again be it understood, that it is not the compulsory division of land by law, as in France and most other continental states, that is here adrocated; but simply the application to it of our own existing law applied to every other form of capital, favouring neither its aggregation nor partition, but leaving it to assume its natural proportions and relation to the wants and habits of socicty, like any other article in which Industry invests its sarings. Wrap yourself in the triple armour of Custom, Prejudiec, or Feudalism, 
immoreable admirer of primogeniture-by-Law; but know that every great and aceredited writer on the Wealth of Nations, from Adam Smith to John Stuart Mill, maintains the freedom of land from the feudal shackles of long entail and primogeniture-by-law, as the prime and fundamental rule of Justice to society in the matter of the Soil. The ehange that we want is but little, but that little underlies and interpenetrates the whole economy of agrieulture as a national business; and renders every acre uneultivated or half eultivated, through the opcration of legal trammels upon the owner, a robbery upon the Labourcr, the Capitalist, and ultimatcly on the public purse. It is the first, and the most natural of Savings-banks to the humble, as well as of Investments to the wealthy, capitalist. It is endowed with the most natural and versatile aptitude to the capabilities of both; it belongs to the Spade as well as the Plough. It is evident as an instinct to every mind, and needs neither proof nor argument, that the soil is the 'primest, eldest' investment of our eapital : to risk our national earnings and accumulations in any other elamel till this ficld is first exhausted, is a course that men may indeed be driven to by the operation of foolish laws or customs, but which few, from cither will or eir- 
eumstanee, wonld roluntarily ehoose. It needed no small ingemity of folly, no small 'method in our madness' to produce that timidity and reluetanee of investment in the soil which the disposable eapital of this rich eountry exhibits. It is almost vain to argue against a feeling. Onee make the eultivators of the soil feel, as a body, that in the Land itself they have really no interest beyond its annual produee, and you poison agrieulture at its souree. Slıallow draining, shallow eultivation, shallow reekonings, and shallow knowledge of lis business, are not naturally inherent in a man beeause he is a 'Tenant-farmer:' but in a country where the law (as happily with us,) reigns supreme, an erroneous law applied to the land may by degrees really make it come to appear so. And this has been the case with us : first by the ineessant reeurrenee of law expenses which our system involves, pressing with every form of eostliness, upon the soil, saddling every landed estate, in addition to the owner, the elergyman, the tenant, the labourer, and the poor, with the maintenance of its Lawyer, - and secondly by denying that last resouree of inherited penury and embarrassed ownership, a free, speedy, and inexpensive mode of Transfer. 'The periodieal ransacking whieh the musty muniments of an interminable 'Title' mu- 
dergo to enable a few acres of land to eliange hands; to say nothing of those momentous occasions, death and marriage, or the eomplete revision of the whole matter whenever a mortgage is required,-form altogether a tribute of such oppressive magnitude, that Protection for the land from foreign empetition is a dream indeed, compared to the reality of the muchdesired Protection from ' Law.' To fully develope and expose the extent to which our antiquated system of Tenures, our long entails strung with disconnected life-interests, our conflicting institution of 'legal' and 'equitable' estates, our prolix conveyances, and complicated settlements, operate as a charge upon the land, an impediment to its exchange, a reduction of its value, a drain upon the resourees of the Owner, a secret injury to the Tenant and the Labourer-would be to write the heaviest satire upon the struggle for Protection that has erer yet been showered upon a class powerful to achieve, if they only willed it, the eompletest satisfaction for the repeal of the Cornlaws which an important body could command, or an intelligent community approve. Do what you will for land, this lies at the bottom of, and eompletely sur. passes in importance all other 'Improvements.' Free the soil from the pestilent tyranny of parehment, that 
the obsolete necessitics and forms of centurics have gathered around it, and more will be accomplished for its increase in commereial value, its preferenee as a field for investment, its promotion of skill and invention, its eontribution to the employment and the happiness of the greatest number, than all the mere physical improvements that could be enumerated or detailed, were every 'Clay Farm' in merry England to supply its 'Chronicle.'

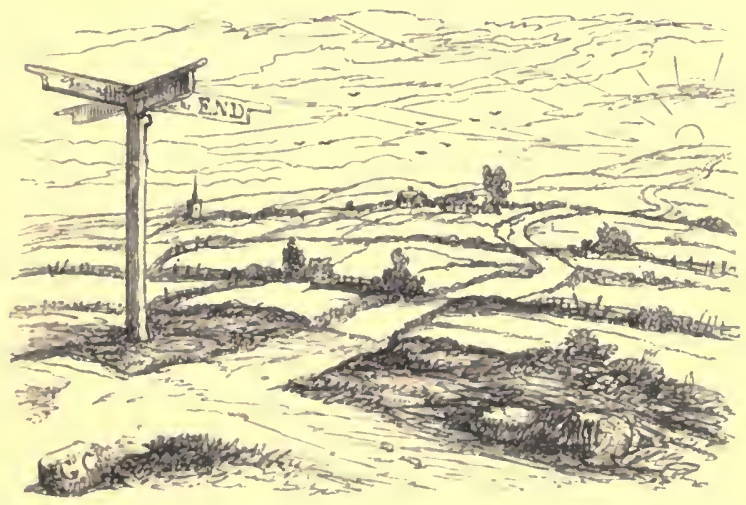





\section{POPULAR NATURAL HISTORY.}

"A popular series of scientiflc treatises, which, from the simplicity of their style, and the artistic excellence and correctness of their numerous illustrations, has acquired a celebrity beyond that of any other series of modern cheap works." -Liverpool StaNdard.

POPULAR HISTORY OF BRITISH ZOOPHYTES. By the Rev. Dr. LANidsborocgri. Twenty Plates, 10s. Gd. coloured.

POPULAR SCRIPTURE ZOOLOGY; or, History of the Auimals mentioned in the Bible. By Maria E. CatLow. Sixteen Plates, $10 s$. $6 d$. eoloured.

POPULAR HISTORY OF BRITISH FERNS, comprising all the Speeies. By Thomas MLoore. With Twenty Plates by Fiteh. $10 s, 6 d$. eoloured.

POPULAR HISTORY OF MOLLUSCA; or, Shells and their Animul Inlabitants. My Marr Roberts. With Eighteen Plates by Wing. $10 s$. $6 d$. eoloured.

POPULAR MINERALOGY, a Familiar Account of Minerals and their Uses. By Hexry Sowerby. With Twenty Plates. 10s. 6d. eoloured.

POPCLAR HISTORY OF BRITISH SEAWEEDS. By the Rev. Dr. Laxpsionotgri. Second Edition. With Tiwenty-two Plates by Fitch. $10 s, 6 d$. eoloured.

POPULAR FIELD BOTANY; a Familiar History of Plants. By Aases Catlow. Third Edition. With Twenty Plates. 10s. 6d. coloured.

POPULAR HISTORY OF MAMMALA. By ADAM White, F.L.S. With Sixteen Plates, by B. Waterhotse. HAWKINS, F.L.S. $10 s .6 d$. coloured.

POPULAR BRITISIL ORNITHOLOGY, comprising all the BIRDS. By P.1I. Gosse. With Twenty Plates. 10s.6d. coloured.

POPLLAR 13RITISII ENTOMOLOGY; a Familiar History of Insects. By Marma E. Catrow. Seeond Edition. With Sisteen Plates by Wist. 10s. G $d$. eoloured.

REEVE \& CO, HEXRIETTA STREET, COVENT GARDEN. 


\section{0 NCHOLOGICAL WORKS}

$\mathbf{B} \mathbf{Y}$

LOVELL REEVE, F.L.S.,

Corresponding Member of the Lyceum of Natural History of New York, and of the Natural Mistory Society of Wurtemberg.

CONCHOLOGIA ICONICA; or, Figures and Descriptions of the Shells of Molluscous Animals, with critical remarks on their synonyms, aflinities, and circumstances of habitation. Demy 4to. Published monthly, in Purts, each containing eight plates. Price $10 \mathrm{~s}$. The figures are drawn and lithographed by Mr. G. B. Sowerby, Jun., of the natural size, from specimens chiefly in the collection of Mr. Cuming.

"This great work is intended to embrace a complete description aud illustration of the shells of molluscous animals; and, so far as we hare seen, it is uot such as to disappoint the large expectations that have been formed respecting it. The figures of the shells are all of full size; in the deseriptions a careful analysis is giveu of the labours of others; and the author has apparently spared no pains to make the work a standard authority on the sulject of which it treats." Athencum.

CONCHOLOGIA SYSTEMATICA; or, Complete System of Conchology, illustrated with 300 plates of upwards of 1500 figures of Shells. In two quarto volumes, cloth. Price E10 coloured; $E 6$ plain.

"The text is both interesting and instructive: many of the plates have ap. peared before in Mr. Sowerby's works, but from the great expense of collecting them, and the niscellaneous manner of their publication, muny persons will no doubt gladly avail themselves of this select and classified portion, which also eontains many original figures."-Athenoum.

\section{ELEMENTS OF CONCHOLOGY; or, Introduction} to the Natural Mistory of Shells and their animals. Parts I. to $\mathrm{X}$. price $3 s$. $6 d$. each.

"The work before us is designed to promote a more philosophic spirit of inquiry into the nature aud origin of Shells."-Ekclesiastical Revieve.

CONCHOLOGIST'S NOMENCLATOR; or, Catalogue of recent species of Shells, with their authorities, symonyms, and references to works where figured or described. By Alines Catrow, assisted by Loveld Refie. In sleets for labels, 20 . Cloth, 21s. Half-bound, intorleared, 25 s.

REEVE \& CO., IIENRIETTA STREET, COVENT GARDEN. 


\title{
REEVE AND CO.'S
}

\section{PUBLICATIONS ON NATURAL HISTORY.}

\author{
ALL BEAUTIFULLY ILLUSTRATED WITH COLOURED
}

PLATES.

Badian's Esculent Fuxguses of Exgland, $\mathfrak{L} s . d$.

Twenty Coloured Plates, super-royal 8vo, eloth

Catlow's Popular Scripture Zoology, Eighteen Coloured Plates, royal 16mo, eloth $\quad \begin{array}{llll}0 & 10 & 6\end{array}$

Catlow's Drops of Water, their marvellous and beautiful Inhabitants, Coloured Plates, square 12 mo, eloth .

Catlow's Popular field Botaxy, third edition, Twenty Coloured Plates, royal 16mo, eloth

Catlow's Popular Britisil Extomology, seeond edition, Sixteen Coloured Plates, royal $16 \mathrm{mo}$, cloth . . . . . . . . . . 0106

Curtis's Britisn Extomology, Seven Hundred and Sixty-nine Coloured Plates, 16 vols. 8 vo, boards . . . . . . . . . . 2100

Curtis's Botanical Magazine (third Series), Vols. I. to VII., royal $8 \mathrm{vo}$, eloth, per vol. $22 \quad 2 \quad 0$

EDwards's Illustrations of the Wisdon ANd Bexeyolexce of the Deity, square 12mo, cloth . . . . . . . . . .

Gardeners Travels ix Brazil, second edition, Svo, eloth . . . . . . . . . . . 0120

Gosse's Popelar Britisi Orxithology, Twenty Coloured Plates, royal 16 ino, eloth $\quad 0 \quad 10 \quad 6$ 
Harvey's Phycologia Britanyica, Vol. I., $£ s . d$. One Hundred and Twenty Coloured Plates, royal 8vo, cloth

Harvey's Phycologia Bratanxica, Vol. II., One Hundred and Twenty Coloured Plates, royal $8 \mathrm{vo}$, cloth

Harvey's Phycologia Britannica, Vol. III., One Hundred and Twenty Coloured Plates, royal 8 vo, eloth .

$\begin{array}{lll}2 & 12 & 6\end{array}$

Harvey's Phycologia Britaxyica, complete in 4 vols., royal 8vo, cloth, arranged systematieally, Thrce Hundred and Sixty Coloured Plates

Harvey's Nereis Australis ; or, Illustrations of the Alge of the Southers Ocens. To be eompleted in Four Parts, Coloured Plates, imperial 8vo, per part . 1110

Hooker's Flora of New Zealand. To be completed in Five Parts, Colourcd Plates, 4to, per part .

Hooker's Flora of New Zealand. To be completed in Five Parts, Plain Plates, 4to, per part

Hooker's Flora Antarctica, One Hundred and Ninety-cight Coloured Plates, 4to, cloth $10 \quad 15 \quad 0$

Hooker's Flora Axtarctica, One Hundred and Ninety-eight Plain Plates, 4to, cloth .

Hooker's Cryptogamia Antarctica, Seventyfour Coloured Plates, 4to, clotll . . . . 4440

Hooker's Cryptogamia Antarctica, Seventyfour Plain Plates, 4to, cloth . . . . . $217 \quad 0$

Hooker's Rilododendrons (first Scries), Ten Coloured Plates, folio

Hooker's Riododendrons (sccond Series), Ten Coloured Plates, folio 
Hooken's Rilododexproxs (third Series), Ten $\quad \& \quad s . d$.

Coloured Plates, folio . . . . . . . . 1500

Hooker's Rirododexpross, complete, Thirty

Coloured Plates, folio, cloth

Hooker's Victoria Regia, elephant folio.

$\begin{array}{lll}1 & 1 & 1\end{array}$

Hooker's Century of Orchidaceus Plaxts,

One Hundred Culoured Plates, 4to, elotlı.

5 i) 0

Hooker's Jourxal or Botayr, Vols. I., II., and III., Coloured Plates, 8vo, boards, per vol.

Hooker's Loxdox Jotrxal of Botaxy, Coloured Plates, Vol. VII., 8vo, eloth .

Hooken's Icones Plaxtaruy (new Series), Vol. V., 8vo, eloth

Hussey's Mrcology, Ninety Coloured Plates, 4to, eloth.

Hessey's Mrcology (second Series), publishing in Parts, Coloured Plates, 4to . .

Ixsecta Britaxica, Vol. I., Diptera, by F. Walker, Ten Plates, Svo, eloth

Jardines Coxtributions to Ornitiology, Published in Parts, Coloured Plates

Dsborocgir's Popllar History of BriTisif SEaweeos, second edition, Twenty Coloured Plates, royal $16 \mathrm{mo}$, eloth

Lasdosoroygh's Popllar British /oopiytes,

Twenty Coloured Plates, royal $16 m o$, .

$0 \quad 106$

Maxy's Planetary axd Stellar Uyiverse, $12 \mathrm{mo}$, eloth

Moore's Popular History of British Fersis, Twenty Coloured l'lates, roval $16 \mathrm{mo}$, cloth

Ralrs's British Desminex, Seventy Coloured Plates, royal svo, cloth 
Reeve's Conchologia Systematica, 2 vols. 4 to, $\quad \mathfrak{E} \quad s . d$. Three Hundred Coloured Plates, eloth . . $\begin{array}{llll}10 & 0 & 0\end{array}$

Reeve's Coxchologia Icoxica, 6 vols., Coloured Plates, 4tor, half-bound . . . . Richardson's Fossil Mammals of tue Voyage of H. M. S. Herald, Fifteen Double Plates, 4to Roberts's Popular History of Moldusca,
Eighteen Coloured Plates, royal 16 mo, cloth Roberts's Popular History of Moldusca,
Eighteen Coloured Plates, royal 16 mo, cloth $\begin{array}{lll}48 & 3 & 0\end{array}$ Roberts's VoICes FroH tile Woodlaxds, Eighteen Coloured Plates, royal 16mo, eloth Saxders's Practical Treatise on the CulTURE of THE VINE, Wood-engravings, 8vo Seemaxy's Narritive of the Voyage of H.M.S. Herald, with Maps and Tinted Lithographs. 2 vols, 8 vo, cloth

Seemaxy's Botaxy of the Voyage of H.M.S. Herald. To be eompleted in Ten Parts, Plates, 4to, per part . . . .

Simth's Parks axd Pleasure Grounds, 8vo, eloth

Sowerby's Popular Mineralogy, Twenty Colonred Plates, royal 16mo, cloth . . . Strickland and Melville's Dodo and its Kivmed, Eighteen Plates and Woodeuts, royal 4 to, cloth

Talpa; or, The Cirronicles of a Clay Fari, with Illustrations by Cruikshank, 12mo, eloth

Thomson's Western Himalaya and Tibet; Maps and 'Tinted Lithographs, Svo, cloth .

$\begin{array}{lll}0 & 10 & 6\end{array}$

$\begin{array}{lll}0 & 10 & 6\end{array}$

$0 \quad 50$

110 



\section{UNIVERSITY OF CALIFORNIA LIBRARY}

\section{Los Angeles}

This book is DUE on the last date stamped below. 


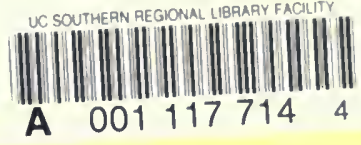

S521

H79t

1853 


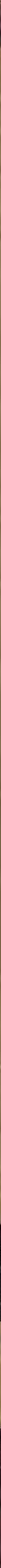

